Brooklyn Law School

BrooklynWorks

Faculty Scholarship

Summer 2006

Subprime Standardization: How Rating Agencies Allow Predatory

Lending to Flourish in the Secondary Mortgage Market

David Reiss

Follow this and additional works at: https://brooklynworks.brooklaw.edu/faculty

Part of the Housing Law Commons, and the Property Law and Real Estate Commons 


\section{SUBPRIME STANDARDIZATION: HOW RATING AGENCIES ALLOW PREDATORY LENDING TO FLOURISH IN THE SECONDARY MORTGAGE MARKET}

\section{DAVID REISS*}

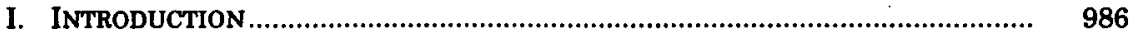

II. THE PROBLEM OF PREDATORY LENDING .................................................. 992

A. The Explosive Growth of the Subprime Mortgage Market........................ 992

B. Predatory Lending in the Subprime Market........................................... 997

III. The Role of Securitization In THE PREDATORY LENDING CRISIS ............... 1001

A. Securitization Explained................................................................. 1001

B. Government-Sponsored Enterprises (GSEs) Create the Secondary Market..

C. The Ongoing Role of GSEs in the Secondary Market ............................ 1009

IV. The Role of Rating agencies in the Securitization of MortgageBACKED SECURITIES

A. How Rating Agencies Rate ................................................................ 1013

B. The Dominant Rating Agencies Enjoy Privileged Regulatory Status as Nationally Recognized Statistical Rating Organizations

C. Ratings by the Privileged Raters Are Biased Against the Public Interest.... 1022

V. PRivileged Raters Gut Strong State PREDAtory Lending Legislation ... 1023

A. The Home Ownership Equity Protection Act Provides Limited Protection... 1025

B. North Carolina Enacts a Predatory Lending Law That Builds Incrementally on Federal Law.

C. The Privileged Raters Initially Underestimate the Impact of State Predatory Lending Legislation.

D. The Georgia Experience: Pushing Forward, Pulled Back...................... 1032

1. The Georgia Fair Lending Act Provides for Assignee Liability and Unquantifiable Damages..

2. The Privileged Raters Exclude Georgia Loans from Their Rated Transactions Because of Concerns That Investors Will Be Liable for Uncapped Damages .

3. As Its Mortgage Market Dries Up, Georgia Acquiesces to the Demands of the Privileged Raters .

4. The Privileged Raters Allow Georgia Loans to Be Securitized Under an Amended Georgia Law

E. The Privileged Raters Take a Stance Against Strong Predatory Lending Legislation.

F. The New Jersey Experience: Testing the Privileged Raters' Resolve......... 1043

1. The Original New Jersey Law.

2. The Privileged Raters Quickly Respond.

3. Standard \& Poor's Backs Down

4. Standard \& Poor's Reverses Course and Imposes New'Restrictions, Forcing New Jersey to Amend Its Law.

VI. THREe Forces MAY StandaRdize tHE OPERATIONS OF THE SUBPRIME MARKET

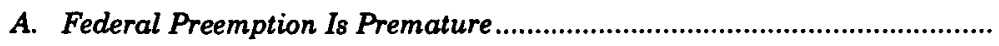

1. Regulatory Preemption...

2. Possible Congressional Preemption ..................................................

B. GSEs Will Have an Incremental Impact....

C. Privileged Raters Are Standardizing the Subprime Market at the Expense of the Public Interest . 
VII. MAKING THE PRIVILEged RATERs TAKE RESPONSIBILITY FOR THEIR IMPACT ON THE PUBLIC INTEREST

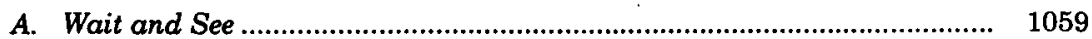

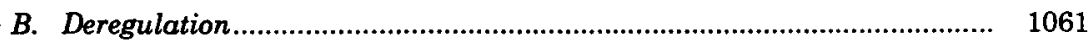

C. Increased Regulation.............................................................................. 1063

VIII. CONCLUSION . 1064

\section{INTRODUCTION}

Predatory lending is today's most pressing consumer protection issue, costing American families over an estimated $\$ 9$ billion a year. ${ }^{1}$ Predatory lending is particularly rampant in the subprime home equity loan market-inhabited largely by unsophisticated borrowerswhere lenders have made billions upon billions of dollars of loans with abusive terms. ${ }^{2}$ After years of legislative and regulatory neglect, state governments have, in recent years, produced a variety of reforms and regulations on the terms and methods of lending in the subprime market, in an attempt to ameliorate the worst aspects of predatory lending.

Specifically, in the last few years, many states have enacted laws to limit abusive home lending practices within their own jurisdictions. ${ }^{3}$ Large segments of the lending industry opposed these laws, claiming that the resulting regulatory patchwork increases their compliance costs, exposes even the most law-abiding lender to liability, and thereby ultimately increases loan costs for consumers. ${ }^{4}$

In large part as a result of these complaints, momentum is building on three fronts to standardize the operations of the subprime mortgage market. First, federal banking regulators in the Office of

* Assistant Professor, Brooklyn Law School; B.A., Williams College; J.D., New York University School of Law. This Article was granted an award as the best academic article on a topic addressing consumer financial services law in 2006 by the American Academy of Consumer Financial Services Lawyers. The author would like to thank the following people for helpful comments on earlier drafts: Baher Azmy, Larry Barnett, Susan Block-Lieb, Dana Brakman-Reiser, Michael Cahill, Neil Cohen, Nestor Davidson, Steven Dean, Jenny Diamond Cheng, James Fanto, Linda Fisher, Claire Hill, Edward Janger, Heidi Kitrosser, Claire Kelly, Rufina Lee, Ronald Mann, Lisa Nicholson, Arthur Pinto, Larry Solan, Ken Zimmerman, and workshop participants at Brooklyn Law School and the AALS 2005 Clinical Conference. The author also acknowledges the support of the Brooklyn Law School Summer Research Stipend Program. Thanks also to Lawrence Hansen and Michael Freedman for excellent research assistance and to the Brooklyn Law School librarians for tirelessly tracking down numerous hard-to-find items.

1. ERIC STEIN, COAL. FOR RESPONSIBLE LENDING, QUANTIFYING THE ECONOMIC COST OF PREDATORY LENDING 3 (2001), http://www.responsiblelending.org/pdfs/Quant10-01.pdf (estimating the annual economic cost of predatory lending to be \$9.1 billion); Christopher A. Richardson, Predatory Lending and Housing Disinvestment, Presentation at Syracuse University, Center for Policy Research 19 (May 17-18, 2003) (transcript available at http://ssrn.com/abstract=338660) (estimating annual cost of predatory lending to be $\$ 9.53$ billion).

2. See infra Part II.B.

3. See infra Part V.

4. See id. 
the Comptroller of Currency (OCC) and the Office of Thrift Supervision (OTS) have already preempted the application of state predatory lending laws to a broad array of lending institutions. ${ }^{5}$ Following the regulators' lead, Congress is also considering legislation to preempt more broadly their application to the remaining financial institutions still subject to state laws. ${ }^{6}$

Second, two government-sponsored enterprises (GSEs), ${ }^{7}$-Fannie Mae and Freddie Mac, the two largest purchasers of residential mortgages on the secondary mortgage market ("secondary market") -indicated that they would not purchase loans from loan originators that contain certain terms they deem abusive, such as harsh prepayment penalties, as well as those loans that are most heavily regulated by predatory lending laws. ${ }^{9}$

Finally, Standard \& Poor's, Moody's Investors Services and Fitch Ratings, the three major bond and securities rating agencies (collectively, the "privileged raters"), indicated that they will not rate securities ${ }^{10}$ backed by pools of residential mortgages if any of those mortgages violate their rating guidelines relating to acceptable liability risk stemming from state predatory lending laws. ${ }^{11}$ Rating agencies are in

5. Baher Azmy, Squaring the Predatory Lending Circle: A Case for States as Laboratories of Experimentation, 57 FLA. L. REV. 295, 358-60 (2005).

6. See infra Part VI.A.

7. The term "GSE" refers to "a federally chartered, privately owned, privately managed financial institution that has only specialized lending and guarantee powers and that bond-market investors perceive as implicitly backed by the federal government." Richard Scott Carnell, Handling the Failure of a Government-Sponsored Enterprise, 80 WASH. L. REV. 565, 570 (2005). Some use the term "Government-Sponsored Entity" instead of "enterprise." See, e.g., note 504 infra. There is no material distinction between these two terms. I use the term "GSEs" as shorthand for Fannie Mae and Freddie Mac, unless otherwise noted, notwithstanding the fact that other entities, such as the Federal Home Loan Bank System, are also GSEs. Carnell, supra, at 573.

8. The market for mortgage-backed securities is known as the "secondary mortgage market," or "secondary market" for short. Amy Crews Cutts et al., Adverse Selection, Licensing and the Role of Securitization in Financial Market Evolution, Structure and Pricing 2 n.1 (July 2001) (unpublished manuscript), available at http://ssrn.com/abstract=280388. The secondary mortgage market is easiest to visualize as "a network of lenders who sell and investors who buy existing mortgages or mortgage-backed securities. This infusion of capital from investors provides mortgage lenders such as banks, thrifts, mortgage bankers and other loan originators with a market for their interests." KENNETH G. LORE \& CAMERON L. COWAN, MORTGAGE-BACKED SECURTTIES $\$ 1.1$ (2005).

9. See infra Part VI.B.

10. There is no single legal definition of a "security." For the purposes of this Article, "security" shall mean "any instrument," such as a mortgage note, "that might be sold as an investment." Reves v. Ernst \& Young, 494 U.S. 56, 61 (1990) (defining "security" for purposes of the Securities Acts).

11. See infra Part VI.C. 
the business of providing credit ratings ${ }^{12}$ for pools ${ }^{13}$ of mortgages that are sold to investors throughout the world, a process known as securitization. The lack of a rating from at least one of the privileged raters, which effectively grant regulatory licenses to institutions that wish to issue securities, ${ }^{14}$ is the financial equivalent of a death sentence for a residential mortgage-backed securities ${ }^{15}$ offering.

Advocates for the lending industry frequently promote the increased standardization of the secondary market as an approach that will reduce predatory behavior without hurting legitimate lenders. ${ }^{16}$ But each of the three methods of standardization described above must be independently evaluated to determine whether it is desirable.

As a preliminary matter, one should also consider the legitimacy of the entity promoting each method of standardization. Obviously, the federal government has broad constitutional authority to regulate financial institutions. ${ }^{17}$ This legitimacy, however, must be balanced against the significant role in banking, consumer protection, and real estate law that is granted to the states in our federal system of governance. While GSEs are private companies, they are federally chartered to provide ongoing assistance to the secondary market so as to help low-and moderate-income individuals become homeowners. ${ }^{18}$ Thus, GSEs have been granted some legitimacy in setting policy in this sphere.

The privileged raters, however, have no similar mandate. They define their role first and foremost as protectors of investors. ${ }^{19}$ And

12. Generally, a credit rating is an evaluation of creditworthiness. Philippe Jorion et al., Informational Effects of Regulation FD: Evidence from Rating Agencies, 76 J. FiN. ECON. 309, 313 (2005). Moody's has defined it as an "opinion of the future ability, legal ob. ligation, and willingness of a bond issuer or other obligor to make full and timely payments on principal and interest due to investors." Id.

13. "A pool is a group of related financial instruments combined for resale to investors on the secondary market." LORE \& COWAN, supra note $8, \S 1.1$.

14. See infra Part IV.B.

15. "Mortgage-backed security" is the general term for "any investment security representing an interest in, or secured by, one or more pools of mortgage loans." LORE \& CowAN, supra note $8, \S 1.1$. 'The term 'mortgage-backed security' is often used to describe securities backed by a wide variety of mortgage interests in almost every conceivable form of real property." Id. By some historical accident, securities backed by home equity loans (HELs) and home equity line of credit (HELOCs) are sometimes referred to as asset-backed securities. See W. Alexander Roever et al., Home Equity Line of Credit (HELOC) Securitizations, in THE HaNDBOOK OF NoNAGENCY MORTGage-Backed Securities 115, 115 (Frank J. Fabozzi et al. eds., 2d ed. 1999) [hereinafter HANDBOOK]. Securities backed by any other asset (such as credit card receivables) are referred to as "asset-backed securities." Global Credit ANAlysis 451 (David Stimpson ed., 1991).

16. See, e.g., Letter from Mortgage Bankers Association to The Honorable Jon Husted, Speaker, Ohio House of Representatives 2 (Mar. 21, 2006) (on file with author) ("A national standard is the better way to achieve our common goal of combating predatory lending.").

17. N. Am. Co. v. SEC, 327 U.S. 686, 706-07 (1946) (stating that federal regulation of securities derives from the Commerce Clause).

18. See infra Part III.B.

19. See infra Part IV.C. 
while they have been granted a privileged regulatory status by the Securities and Exchange Commission (SEC) and other government regulators, ${ }^{20}$ they have not been assigned a reciprocal responsibility to the public, as GSEs have been. As a result of this mismatch between privilege and responsibility, those concerned with the rights of homeowners should meet the privileged raters' efforts to impose standardization on the mortgage market with greater skepticism.

The most significant criticism of the federal preemption of state predatory lending laws is that it is too soon to do so. ${ }^{21}$ Predatory lending has only arisen as a significant problem in the last decade, and not enough time has passed to say whether legislators and regulators have come up with the best solution to the problem. ${ }^{22}$ States, playing their traditional role as laboratories for policy experimentation, ${ }^{23}$ should be left alone until the relative merits of different approaches to the problem can be compared. ${ }^{24}$

The GSE approach is probably the most limited of the three and the one least likely to harm homeowners. This is because GSEs must balance their profit-seeking with the effectuation of their public purpose. ${ }^{25}$. Because Congress and the media watch them carefully and because they have competitors in the secondary market, the GSEs' incremental approach is likely to do some good: it should reduce the number of loans with abusive terms without exercising an effective veto over state predatory lending laws. ${ }^{26}$

Unsurprisingly, the most worrisome of the three approaches to standardization is that of the privileged raters. The privileged raters have implemented guidelines relating to predatory lending legislation that do not accurately measure the risk that such statutes pose to investors. In particular, they exaggerate the risk posed by assignee liability and punitive damages provisions in such legislation. ${ }^{27}$ Ultimately, these guidelines have had two major impacts: (1) they

20. See infra Part IV.B.

21. See infra Part VI.A.

22. See id.

23. New State Ice Co. v. Liebman, 285 U.S. 262 (1932) (Brandeis, J., dissenting) ("It is one of the happy incidents of the federal system that a single courageous state may, if its citizens choose, serve as a laboratory ....").

24. See Wei Li \& Keith S. ERnSt, Center for Responsible Lending, The Best VALUE IN THE SUBPRIME MARKET: STATE PREDATORY LENDING REFORMS 12, 17 (2006), http://responsiblelending.org/pdfs/rr010-State_Effects-0206.pdf. This study, analyzing data from 1998-2004, finds that states with strong predatory lending laws have been successful at reducing the number of subprime loans with abusive terms, while not reducing the amount of capital available or raising interests rates for subprime consumers. Id. For example, subprime loans with abusive terms in New Jersey declined thirty-seven percent lower than states without strong predatory lending laws, and interest rates fell approximately thirty-two basis points on those loans.

25. See infra Part III.C.

26. See infra Part VI.B.

27. See infra Part V. 
promote the interests of issuers and investors over those of homeowners, and (2) they promote the growth of the residential mortgagebacked securities market. ${ }^{28}$ Not coincidentally, the privileged raters make more money in such a growing market because they charge issuers for their work in rating new securities. Thus, it is in the privileged raters' self-interest to keep states from passing laws that slow secondary market growth and cut into their income. ${ }^{29}$

There is no way to formally or informally appeal the decisions of the privileged raters. And because there is no adequate way to exercise public pressure on them, their misjudgments interfere with legitimate state policies to the benefit of the privileged raters themselves, which amounts to an abuse of the privileges that they have been granted by government regulators. The privileged raters' actions have caused some state legislatures to water down predatory lending bills under consideration and have caused others to amend and dilute existing predatory lending laws so that the privileged raters will continue to rate pools containing loans from states with such laws. ${ }^{30}$ This is because funds for loans can dry up in a jurisdiction that has enacted a tough predatory lending law that falls afoul of the privileged raters' guidelines. As this catastrophic scenario has already occurred in one state, others have quickly learned that the privileged raters have an effective veto over their predatory lending laws. ${ }^{31}$

This Article reviews all three efforts to standardize the subprime mortgage market, but it focuses on the privileged raters' actions because they present a serious and unjustified impediment to the remediation of serious abuses in the home mortgage market that has not yet received thorough scholarly attention.

In order to understand how privileged raters became so enmeshed with predatory lending, we must first understand how two related processes work: (1) the marketing of subprime loans to consumers and (2) the role of the privileged raters in the expansion of the subprime mortgage market.

To explain these processes, this Article builds on a growing body of predatory lending and rating agency literature. Professors Kurt Eggert, Kathleen Engel, and Patricia McCoy have documented and explained the link between predatory lending and the secondary market. $^{32}$ Professors Claire Hill, Frank Partnoy, and Steven Schwarcz

28. See infra Part VI.C.

29. See id.

30. See infra Part V.

31. See id.

32. See, e.g., Kurt Eggert, Held Up in Due Course: Codification and the Victory of Form over Intent in Negotiable Instrument Law, 35 CREIGHTON L. REV. 363, 363-68 (2002) [hereinafter Eggert, Codification]; Kurt Eggert, Held Up in Due Course: Predatory Lending, Securitization, and the Holder in Due Course Doctrine, 35 CREIGHTON L. REv. 503, 
have documented and explained the role of rating agencies in the broader financial markets. ${ }^{33}$ Building on these two bodies of work and on the significant economics and finance literature relating to rating agencies, the aim of this Article is to demonstrate that privileged raters are playing an active, albeit hidden, role in permitting predatory lending to thrive. A limitation of the existing rating agency literature, at least for my purposes, is that it has not evaluated privileged raters' impact on predatory lending and, thus, on the public interest. The term "public interest," for the purposes of this Article, refers to the expressed preferences of a political entity, such as one might find in a law passed by a state legislature. As far as this body of literature is concerned, the only relevant parties are investors, issuers and the agencies themselves. I add the public to that list.

Part II of this Article describes the process of marketing subprime loans to consumers and describes the way predatory lending grew alongside the extraordinary and rapid expansion of the subprime lending market. Part III explains how mortgages are securitized and sold. Part III also describes how GSEs created a standardized secondary market for prime loans and how they are in the process of standardizing aspects of the subprime secondary market. Part IV describes the function of rating agencies in the securitization process as well as the process by which they arrive at their ratings. Part IV also describes how the privileged raters have been granted a privileged regulatory status by financial services regulators. Finally, this Part reviews recent finance scholarship that suggests that the privileged raters are biased against the public interest in general and the interest of homeowners in particular.

Part V outlines existing remedies for predatory lending and describes in detail the impact of the privileged raters on the structure of three state predatory lending laws enacted in North Carolina, Georgia, and New Jersey. Part V also documents how the privileged raters overreacted-and continue to overreact-to those statutes. The state-specific detail of Part $V$ is necessary for my argument for two reasons. First, states are the battleground upon which financial companies like the privileged raters have fought against increased regu-

511-22 (2002) [hereinafter Eggert, Predatory Lending]; Kathleen C. Engel \& Patricia A. McCoy, A Tale of Three Markets: The Law and Economics of Predatory Lending, $80 \mathrm{TEX}$. L. REV. 1255, 1270-98 (2002) [hereinafter Engel \& McCoy, Three Markets]; Kathleen C. Engel \& Patricia A. McCoy, Predatory Lending: What Does Wall Street Have to Do with It?, 15 HOUSING POL'Y DEBATE 715, 715-20 (2004) [hereinafter Engel \& McCoy, Wall Street].

33. See, e.g., Claire A. Hill, Regulating the Rating Agencies, 82 WASH. U. L.Q. 43, 46-64 (2004); Frank Partnoy, The Siskel and Ebert of Financial Markets?: Two Thumbs Down for the Credit Rating Agencies, 77 WASH. U. L.Q. 619, 627-54 (1999); Steven L. Schwarcz, Private Ordering of Public Markets: The Rating Agency Paradox, 2002 U. ILL. L. REV. 1, 15; see also Arthur Pinto, Control and Responsibility of Credit Rating Agencies in the United States, AM. J. COMP. L. (forthcoming 2006) (providing an overview of U.S. credit rating industry). 
lation of the secondary market. Second, the events in each state are merely battles in a broader war between local control and international capital market standardization, and this intangible and ongoing war cannot be understood without those details. In sum, Part V provides a case study of how the privileged raters' privileged regulatory status distorts the efficient functioning of the financial markets to the advantage of financial market participants and to the detriment of the public interest.

Part VI is a review of the impact that federal preemption, the GSEs, and the privileged raters have on the healthy standardization of the subprime secondary market. I conclude that federal preemption is premature; GSEs are having an incremental and beneficial impact on the subprime market, and the privileged raters are having a negative impact. Part VII builds on various reforms suggested in the rating agency literature to propose public policy responses to the standardization imposed by rating agencies on the secondary market. A thorough exploration of such proposed solutions must be left to a later article. Nonetheless, by applying the insights of the predatory lending and rating agency literature to the events surrounding the adoption of recent state predatory lending legislation, this Article makes visible the distortions that the privileged raters have caused in the secondary market, particularly as it affects the public interest.

\section{The PRoBlem of PREDATORY LENDING}

\section{A. The Explosive Growth of the Subprime Mortgage Market}

The way that Americans borrow money to buy homes has changed radically since the $1980 \mathrm{~s}^{34}$ Before that time, Americans who wanted to buy a home would typically walk into their local savings and loan and speak to a loan officer who would evaluate their application. ${ }^{35}$ Depending on income, wealth, and ties to the community, the loan officer might have approved a loan. And typically, only those with a

34. See Michael J. Lea, Innovation and the Cost of Mortgage Credit: A Historical Perspective, 7 HOUSING POL'Y DEBATE 147, 166-72 (1996) thereinafter Lea, Historical Perspective] (describing the history of mortgage lending in United States from 1980s to the mid1990s); Michael J. Lea, Sources of Funds for Mortgage Finance, 1 J. Housing Res. 139, 150-53 (1990) [hereinafter Lea, Sources of Funds] (describing the role of government in mortgage lending from the Great Depression through the 1980s); Amy Crews Cutts \& Robert Van Order, On the Economics of Subprime Lending 1 (Freddie Mac, Working Paper No. 04-01, 2004), available at http://www.freddiemac.com/news/pdf/subprime_012704.pdf.

35. See Robert Van Order, The U.S. Mortgage Market: A Model of Dueling Charters, 11 J. HousING RES. 233, 233 (2000) ("Between the end of World War II and the 1970s, U.S. residential mortgage markets were dominated by the primary market, which was comprised primarily of specialized depository institutions (mainly savings and loan associations [S\&Ls], more broadly 'thrifts'), which both by regulation and tax incentive were induced to hold most (about 80 percent) of their assets in mortgages."). 
healthy, or "prime," profile were approved..$^{36}$ That is, they had a steady work history, a large down payment, and no problems with their credit. ${ }^{37}$

Thrifts $^{38}$ were not only the dominant type of lender, but they also vertically dominated the residential mortgage market. They originated and serviced the mortgage typically holding it until it was paid off by the borrower. ${ }^{39}$ Now, technological, ${ }^{40}$ financial $^{41}$ and legal ${ }^{42}$ innovations allow global finance companies to offer a range of mortgage

36. "Prime" mortgages share certain characteristics relating to their "type, duration, age, performance, and other specific criteria." SECURITIZATION: ASSET-BACKED AND MORTGAGE-BACKED SECURITIES § 9.04, at 9-21 (Ronald S. Borod ed., 2003) [hereinafter SECURITIZATION]. In order to determine the "necessary level of credit enhancements for financing," rating agencies have developed a "list of the characteristics [that] a "prime pool' of residential mortgages" would include. This list includes the following:

\begin{tabular}{|l|l|}
\hline Mortgage Security & $\begin{array}{l}\text { First lien on single family de- } \\
\text { tached properties for use as a } \\
\text { primary residence located in } \\
\text { the United States }\end{array}$ \\
\hline Amortization & $\begin{array}{l}\text { Fixed-rate level fully amortiz- } \\
\text { ing payments }\end{array}$ \\
\hline Loan to Value Ratio & $\begin{array}{l}80 \% \text { loan to value, as estab- } \\
\text { lished by a competent ap- } \\
\text { praiser }\end{array}$ \\
\hline Maximum Mortgage Size & $\begin{array}{l}\text { \$400,000 (Standard \& Poor's. } \\
\text { Some rating agencies limit size } \\
\text { of loan to Fannie Mae loan } \\
\text { limit size) }\end{array}$ \\
\hline Loan Documentation & $\begin{array}{l}\text { Standard, complete } \\
\text { FHLMC/FNMA documentation }\end{array}$ \\
\hline Minimum Number of Loans & $\begin{array}{l}300, \text { with geographical disper- } \\
\text { sion }\end{array}$ \\
\hline
\end{tabular}

Id. at 9.21 to 9.22.

37. See Debra Pogrund Stark, Unmasking the Predatory Loan in Sheep's Clothing: $A$ Legislative Proposal, 21 HARV. BLACKLETTER L.J. 129, 131-32 \& n.10 (2005) (describing typical post-World War II loan application process).

38. The term "thrifts" is a catchall that includes savings and loans, savings banks, and mutual savings banks. 12 U.S.C. $\$ 1841$ (i) (2000) (defining "thrift institutions" for the purposes of the Bank Holding Company Act of 1956).

39. Van Order, supra note 35, at 233.

40. See, e.g., Andrea Heuson et al., Credit Scoring and Mortgage Securitization: Implications for Mortgage Rates and Credit Availability, 23 J. REAL EST. FIN. \& ECON. 337, 338 (2001) ("With the recent advent of automated underwriting, much of the informational advantage [of mortgage originators] has disappeared. As the argument goes, computerized credit scoring gives the securitizer more accurate and timely information about borrower creditworthiness.").

41. See, e.g., Cutts \& Van Order, supra note 34, at 1 ("U.S. mortgage markets have evolved radically in recent years. Innovations in underwriting, mortgage products, and mortgage funding have expanded mortgage lending and reduced costs.").

42. See, e.g., U.S. Gen. Accounting Office, Consumer Protection: Federal AND State AgEncies FaCe Challenges In COMBATING PREDATORY LENDING 21 (2004), available at http://www.gao.gov/new.items/d04280.pdf [hereinafter GAO, CoNSUMER PROTECTION] ("Several factors account for the growth of the subprime market, including changes in tax law that increased the tax advantages of home equity loans ....'”. 
products to a broad array of potential residential borrowers. As a result of these innovations, there has been an unbundling of the submarkets of the mortgage industry.

A mortgage now can be:

(1) originated by a mortgage broker who makes money only from origination;

(2) serviced by a mortgage banker who did not originate the loan and may have bought the right to service the loan from another mortgage banker;

(3) originated with the credit risk taken by one of the secondary market institutions, perhaps along with a mortgage insurance company; and

(4) funded by a mortgage-backed security (MBS) sold into the capital markets, and the MBS can be packaged as a bundle of derivative securities that separate interest rate and prepayment risk among different investors. ${ }^{43}$

A highly beneficial consequence of this change has been the economies of scale that specialized firms have been able to achieve, which has resulted in rated MBS transactions trading at only a small discount to Treasury securities of comparable maturity. ${ }^{44}$ This has driven down the average interest rate paid by homeowners. ${ }^{45}$ In part because of those changes, in 2004, American homeownership had reached a historic high of $69 \%$, and Americans had $\$ 9.6$ trillion in home equity. ${ }^{46}$ Indeed, lenders refinanced trillions of dollars of mortgages in 2003 and $2004 .{ }^{47}$

"Subprime" lending has been a significant and growing portion of this activity, reaching nearly $20 \%$ of all originations in $2004 .{ }^{48} \mathrm{Sub}$ prime lending is the extension of credit to those with lower incomes, less wealth, and riskier credit profiles than traditional, "prime" borrowers. ${ }^{49} \mathrm{~A}$ negative consequence of the change in the mortgage in-

43. Van Order, supra note 35, at 233-34.

44. Id. at 234 ("Pools of mortgages (MBS and their derivatives) and debt backed by pools of mortgages now trade in national and international markets, almost as efficiently as Treasury securities.").

45. See id.

46. JoINT CTR. For Hous. Studies of HaRvard U., The State of The Nation's Housing 2005, at 1, 5 (2005).

47. Id. at 5.

48. See id. at 17.

49. See Cutts \& Van Order, supra note 34, at 4-5; see also KENNETH TEMKIN ET AL., U.S. DEP'T OF HOUS. \& URBAN DEV., SUBPRIME MARKETS, THE ROLE OF GSES, AND RISKBASED PRICING 8 (2002) ("[The Depository Institutions Deregulation and Monetary Control Act and the Alternative Mortgage Transactions Parity Act] provide the legal framework for subprime lending, except in states that opt out of the legislation."); Baher Azmy \& David Reiss, Modeling a Response to Predatory Lending: The New Jersey Home Ownership Security Act of 2002, 35 RUTGERS L.J. 645, 652 (2004) (discussing a range of factors that have led to increase of subprime lending). 
dustry away from dominance by thrifts and toward relatively unregulated specialty firms has resulted in a variety of abuses in the subprime portion of the secondary market.

Subprime lenders typically offer three types of products to borrowers. ${ }^{50}$ First, refinance and purchase mortgages are offered to borrowers with poor credit histories. ${ }^{51}$ In many cases, borrowers refinance mortgages for an amount greater than the balance of the original mortgage, thereby taking "cash out" of their homes. ${ }^{52}$ Second, "Alt-A" mortgages are made to borrowers with FICO scores similar to those in the prime market. ${ }^{53}$ Alt-A mortgages are typically made to borrowers who cannot document all of the information in their loan application ("low doc" or "no-doc" loans); Alt-A mortgages can be used either for a purchase or a refinance. ${ }^{54}$ Third, high loan-to-value $(L T V)^{55}$ refinance mortgages are originated to borrowers with relatively good credit but who have LTV ratios that sometimes are as high as $150 \% .^{56}$

Subprime loans have higher interest rates than prime loans, a fact that lenders ascribe to the subprime borrowers' greater risk of default. ${ }^{57} \mathrm{~A}$ number of studies have estimated that subprime interest rates for $\mathrm{C}$ and $\mathrm{D}$ subprime loans are on average four percentage points higher than those for prime loans. ${ }^{58}$ Generally, subprime lenders also charge higher points and fees, that is, charges assessed at

50. TEMKIN ET AL., supra note 49 , at 4.

51. Id.

52. Id.

53. Id. The FICO ratings system, created by the Fair Isaac Corporation, gives individual consumers credit scores that are meant to predict whether they will pay their debt obligations as expected by lenders. See Fairlsaac, Credit Bureau Risk Scores, http://www.fairisaac.com/ Fairisaad/Solutions/Scoring++Predictive+Modeling/Credit+Bureau+Risk+Scores.htm (last visited Mar. 10, 2006). Some argue that Alt-A mortgages are not as safe as genuine "A" mortgages. See Cutts \& Van Order, supra note 34 , at 4.

54. TEMKIN ET AL., supra note 49, at 4. "No document" loans are made to borrowers who have irregular income, such as those working on commission. Id. Because their recent income statements may not reflect their income accurately, lenders will rely on high credit scores and a higher interest rate to ensure that they are adequately protected against the additional risk of lending to such individuals. Id.

55. That is, the principal amount of the loan is very high in relation to the value of the house that is mortgaged to secure that loan. Until the 1990s, residential lenders typically limited the LTV to $80 \%$. Rick Grant, Subprime Mortgage Lending Comes of Age, NAT'L MORTGAGE NEWS, Dec. 29, 1997, at 12 ('In the not-80-distant past, high LTV meant anything above what the GSEs would accept (70-80\% of appraised value), but in today's marketplace it can mean up to $150 \%$ or more of the home's value.").

56. TEMKIN ET AL., supra note 49 , at 4 .

57. HUd-Treasury task Force on Predatory lending, Curbing Predatory HOME MORTGAGE LENDING 27.28 (2000) [hereinafter JOINT HUD-TREASURY REPORT].

58. Id. at 28. Within the subprime market, grades of A-, B, C, and D are assigned to represent progressively higher credit risks carrying correspondingly higher interest rates. See Anthony Pennington-Cross, Subprime \& Prime Mortgages: Loss Distributions 1 (OFHEO Working Papers, Working Paper No. 03-1, 2003), available at http://www.ofheo.gov/media/ pdf/03-1subprime.pdf. 
the outset of the loan and paid either in cash or financed into the overall loan proceeds, to compensate for higher origination and servicing costs that lenders claim subprime loans have. ${ }^{59}$ In the aggregate, loan performance data appears to support the view that a significant portion of the excess spread ${ }^{60}$ covers the higher risk of default among subprime loans: as of September 2000 , only $3.36 \%$ of subprime mortgages in the A- range, while $21 \%$ of $\mathrm{D}$ mortgages were seriously delinquent. ${ }^{61}$ These rates of delinquency were far higher than those in the prime market, where only $0.54 \%$ of loans were seriously delinquent. ${ }^{62}$

Most subprime loans are now originated by mortgage and consumer finance companies, with a smaller amount issued by banks and thrifts. ${ }^{63}$ And only $16 \%$ of subprime mortgages are used for home purchases. ${ }^{64}$ That is, most subprime mortgages are used to refinance existing mortgages. ${ }^{65}$ The growth of subprime lending has been utterly explosive. In 1994, subprime mortgage originations were $\$ 34$ billion; in 2002 they represented $8.6 \%$ of all originations, over $\$ 213$ billion. ${ }^{66}$ The secondary market provides much of the liquidity and capacity for growth for the subprime market. ${ }^{67}$ Indeed, in 2003, "approximately two-thirds of the outstanding subprime/home equity loans in the United States were securitized."68

This growth has allowed many people who had not been able to access the prime market to access the equity in their homes. This greater access to credit in the subprime market has come at the cost

59. JoHN C. WeICHER, THE HoMe EQUTTY LENDING INDUSTRY 68 (1997). It remains unclear, however, the extent to which subprime loan terms accurately reflect an inherent market risk of default associated with their borrowers. See Cutts \& Van Order, supra note 34 , at 5-6. (noting that differences in subprime loans "broadly justify higher rates" but do not "indicate how much higher the rates should be").

60. "Excess spread is the difference between (1) interest received at the weighted average interest rate on the mortgage collateral and (2) the sum of interest paid at the passthrough rate on the bonds and any monthly fees." Abner Figueroa, The Evaluation of Excess Spread in Sub-Prime Transactions, in HANDBOoK, supra note 15, at 209, 209. For instance, if the weighted average interest rate of a pool of mortgages was $7 \%$ and the sum of interest paid (including fees) was $6 \%$, the excess spread would be one percentage point. That excess spread may be used to cover the higher costs of subprime lending and any remainder may be kept by the issuer and/or shared with investors.

61. TEMKIN ET AL., supra note 49 , at 19.

62. Id.

63. GAO, Consumer Protection, supra note 42, at 22. In 2001, "178 lenders concentrated primarily on subprime mortgage lending." Id. "Fifty-nine percent of these lenders were independent mortgage companies (mortgage bankers and finance companies), 20 percent were nonbank subsidiaries of financial or bank holding companies, and the remainder were other types of financial institutions. Only 10 percent were federally regulated banks and thrifts." Id.

64. TEMKIN ET AL., supra note 49 , at 5 .

65. Id.

66. GAO, CONSUMER PROTECTION, supra note 42, at 21.

67. See TEMKIN ET AL., supra note 49 , at 9.

68. Engel \& McCoy, Wall Street, supra note 32 , at 719 n.5. 
of significantly higher fees and interest rates than a prime borrower would face. ${ }^{69}$ It has also come at the cost of significantly higher fees and interest rates for minority borrowers as compared to white borrowers, and these higher costs are not efficiently related to the comparative credit risk of white and minority borrowers. ${ }^{70}$ In other words, the subprime market in the aggregate appears to discriminate to some extent against communities of color.

Communities of color have been disproportionately represented in the subprime market in contrast to their representation in the prime market. African Americans and Hispanics combined made up less than $8 \%$ of the prime home purchase mortgage market in 1998 , but such borrowers made up nearly $20 \%$ of subprime home purchase mortgage market in that same year. ${ }^{11}$ Similarly, African-American and Hispanic borrowers together make up about $6 \%$ of all prime conventional refinance mortgages and $17 \%$ of subprime refinance mortgages. ${ }^{72}$ And more than half of all loans in predominantly AfricanAmerican communities are subprime, compared to only $9 \%$ of loans in predominantly white communities. ${ }^{73}$

\section{B. Predatory Lending in the Subprime Market}

The subprime market is far less regulated and standardized than the prime market. As such, it presents an opportunity for those seeking to separate financially unsophisticated borrowers from the equity that they have in their homes. That is, it presents an opportunity to engage in predatory lending. ${ }^{74}$ Most predatory behavior takes place between a mortgage broker or mortgage banker and the borrower. ${ }^{75}$

69. See Michael S. Barr, Modes of Credit Market Regulation, in BuIL.DING ASSETS, BuILDING WEALTH: CREATING WEALTH IN LOW-INCOME COMMUNITIES (Nicolas P. Retsinas \& Eric S. Belsky eds., 2005) (reviewing credit market price discrimination literature).

70. Azmy, supra note 5, at 321-26.

71. TEMKIN ET AL., supra note 49 , at 5 .

72. Id.

73. U.S. DEP'T OF HOUS. \& URBAN DEV., UNEQUAL BURDEN: INCOME AND RACIAL DISPARITIES IN SUBPRIME LENDING IN AMERICA (2000), http:/hud.gov/library/bookshelf18/ pressrel/subprime.html [hereinafter HUD, UNEQUAL BURDEN]. In 1998, 26\% of refinance loans in low-income communities were subprime, compared to a national average of $11 \%$ and $7 \%$ in upper-income communities. Id. This may partially be the result of the lower income-to-asset ratios and shorter or weaker credit histories found among such borrowers.

74. See Eggert, Predatory Lending, supra note 32, at 511-13 (surveying a variety of definitions of predatory lending proposed by scholars and regulators); see also Engel \& McCoy, Three Markets, supra note 32, at 1260 (suggesting that predatory lending includes "(1) loans structured to result in seriously disproportionate net harm to borrowers, (2) harmful rent seeking, (3) loans involving fraud or deceptive practices, (4) other forms of lack of transparency in loans that are not actionable as fraud, and (5) loans that require borrowers to waive meaningful legal redress").

75. See generally Lawrence Hansen, In Brokers We Trust-Mortgage Licensing Statutes Address Predatory Lending, 14 J. AFFORDABLE Housing \& CoMMUNITY Dev. L. 332 (2005) (describing predatory practices by originators). 
But such thinly funded entities could not exist with funding from secondary market investors. This Article focuses on how states have attempted to make secondary market investors accountable for their role in propagating predatory lending, thereby incentivizing them to stop it. ${ }^{76}$

While the extent to which predatory lending has infiltrated the subprime market cannot be known precisely, "it is rare to find a case of a predatory lending that does not involve a subprime lender," as opposed to a prime lender ${ }^{78}$ Predatory lending is also far more common in the "refinance" or "home equity" market" than in the home purchase market because home equity borrowers have much more equity in their home than purchasers: the existing home equity gives predatory lenders a greater opportunity to pack a loan with excessive fees that might not be readily identifiable by the borrower who needs not pay such increased out-of-pocket costs as a new homeowner would. ${ }^{80}$

While there is no generally accepted comprehensive definition of predatory lending, ${ }^{81}$ the U.S. General Accounting Office (GAO) has cobbled together a good working description: "an umbrella term that

76. See Engel \& McCoy, Wall Street, supra note 32, at 716 ("If the secondary market has the incentive and ability to deter predatory lending through such market devices as pricing, contract provisions, due diligence, and monitoring, then the market for subprime mortgages arguably will self-correct.").

77. There is no systematic data on predatory lending in large part because the "principle source of information on mortgage lending is data reported under [the Home Mortgage Disclosure Act (HMDA)], but HMDA does not include information on interest rates, fees, points, or other costs that might be indicative of predatory lending practices." Harold L. Bunce et al., Subprime Foreclosures: The Smoking Gun of Predatory Lending?, in Housing Policy IN THE NeW MILlenniUM: Conference PRocendings 257, 259 (Susan M. Wachter \& R. Leo Penne eds., 2001). Notwithstanding these limitations, "HMDA data is the most comprehensive source of information on primary mortgage originations and secondary market loan purchases." Randall M. Scheessele, HMDA Coverage of the Mortgage Market 4 (Hous. Fin. Working Paper Series, Working Paper No. HF-007, 1998). HMDA data does provide information on the borrower, such as income, race, ethnicity and sex, as well as information regarding the property to be mortgaged, such as location. Id.

78. Dan Immergluck, Stark Differences: Explosion of the Subprime Industry and Racial Hypersegmentation in Home Equity Lending, in HoUSING POLICY IN THE NEW MILLENNIUM: CONFERENCE PROCEEDINGS, supra note 77, at 237.

79. Charles Schorin et al., Home Equity Loans, in HANDBOOK, supra note 15, at 79, 83. The term "home equity loan" covers many different products; it includes the traditional second lien mortgage, but "it more commonly today refers to first liens to borrowers with impaired credit histories" and/or high debt-to-income ratios. Id. at 79. Home equity loans are typically used to "consolidate consumer debt in a lower, tax deductible form [;] reduce a homeowner's monthly mortgage payment by extending the loan's term[;] finance home improvements[;] monetize equity in the home[;] finance temporary liquidity needs, such as for education or medical expenses." Id. at 84-85.

80. See GAO, CONSUMER PROTECTION, supra note 42, at 20 ("According to federal and industry officials, most predatory mortgage lending involves home equity loans or loan refinancings rather than loans for home purchases.").

81. See Azmy \& Reiss, supra note 49 , at 649 \& nn.8-10 (discussing difficulties of comprehensively defining predatory lending). 
is generally used to describe cases in which a broker or originating lender takes unfair advantage of a borrower, often through deception, fraud, or manipulation, to make a loan that contains terms that are disadvantageous to the borrower." ${ }^{82}$ Accordingly, the GAO has defined predatory lending so as to include the following abusive practices and loan terms:

(1) Excessive fees. Abusive loans may include fees that greatly exceed the amounts justified by the costs of the services provided and the credit and interest rate risks involved. Lenders may add these fees to the loan amounts rather than requiring payment up front, so the borrowers may not know the exact amount of the fees they are paying.

(2) Excessive interest rates. . . . [L]enders may charge interest rates that far exceed what would be justified by any risk-based pricing calculation, or lenders may "steer" a borrower with an excellent credit record to a higher-rate loan intended for borrowers with poor credit histories.

(3) Single-premium credit insurance. Credit insurance is a loan product that repays the lender should the borrower die or become disabled. In the case of singlepremium credit insurance, the full premium is paid all at once-by being added to the amount financed in the loan-rather than on a monthly basis....

(4) Lending without regard to ability to repay. Loans may be made without regard to a borrower's ability to repay the loan. In these cases, the loan is approved based on the value of the asset (the home) that is used as collateral. In particularly egregious cases, monthly loan payments have equaled or exceeded the borrower's total monthly income. Such lending can quickly lead to foreclosure of the property.

(5) Loan flipping. Mortgage originators may refinance borrowers' loans repeatedly in a short period of time without any economic gain for the borrower. With each successive refinancing, these originators charge high fees that "strip" borrowers' equity in their homes.

(6) Fraud and deception. Predatory lenders may perpetrate outright fraud through actions such as inflating property appraisals and doctoring loan applications and settlement documents. Lenders may also deceive borrowers by using "bait and switch" tactics that mis-

82. GAO, Consumer PROTECTION, supra note 42, at 18. Independent mortgage brokers typically sell loans that they originate to lenders for premiums ranging from $2.5 \%$. Fitch IBCA, SUBPRIME HOME EquiTY: WhAT NEXT? 8 (Apr. 27, 1999). 
lead borrowers about the terms of their loan. Unscrupulous lenders may fail to disclose items as required by law or in other ways may take advantage of borrowers' lack of financial sophistication.

Prepayment penalties. Penalties for prepaying a loan are not necessarily abusive, but predatory lenders may use them to trap borrowers in high-cost loans.

(8) Balloon payments. Loans with balloon payments are structured so that monthly payments are lower but one large payment (the balloon payment) is due when the loan matures. Predatory loans may contain a balloon payment that the borrower is unlikely to be able to afford, resulting in foreclosure or refinancing with additional high costs and fees. Sometimes, lenders market a low monthly payment with. out adequate disclosure of the balloon payment. ${ }^{83}$

Predatory practices are not typically present in the prime market. Indeed, they are present in much of the subprime market, ${ }^{84}$ where low- and moderate-income borrowers are concentrated. ${ }^{85}$ But they are used to prey on unsophisticated homeowners, typically those who are not integrated in the sphere of mainstream financial institutions such as banks and credit unions. ${ }^{86}$

According to the Senate hearing testimony of an anonymous employee of a predatory lender, the

perfect customer [for a predatory finance company] would be an uneducated widow who is on a fixed income-hopefully from her deceased husband's pension and Social Security, who has her house paid off, is living off of credit cards, but having a difficult time keeping up her payments and who must make a car payment in addition to her credit card payments. ${ }^{87}$

Such predatory practices lead to foreclosure: from January 1998 through September 1999, "the foreclosure rate for subprime loans was more than [ten] times the foreclosure rate for prime loans."

83. GAO, Consumer Protection, supra note 42, at 18-19.

84. See Azmy \& Reiss, supra note 49 , at $655-56$ (discussing tactics of predatory lenders).

85. HUD, UNEQUAL BURDEN, supra note 73.

86. See James H. Carr \& Jenny Schuetz., Financial Services in Distressed Communities: Framing the Issue, Finding Solutions, in Financial SERVICES IN DisTressed COMmunities: Issues AND ANSWERS 5, 6 (Fannie Mae Found. 2001) ("As many as 12 million households in the United States either have no relationship with traditional financial institutions or depend on fringe lenders for financial services. These households are disproportionately poor and minority.").

87. Equity. Predators: Stripping, Flipping and Packing Their Way to Profits: Hearing Before the S. Special Comm. on Aging, 105th Cong. 31 (1998) (statement of "Jim Dough," Former Employee of a Predatory Lender).

88. GAO, CONSUMER PROTECTION, supra note 42, at 24. 
While the increased credit risk of subprime borrowers explains part of this extraordinary differential, it also appears to be the result, in large part, of predatory lending. ${ }^{89}$

\section{The Role of SeCURITIZation IN THE PREDATORY LENDING CRISIS}

Real estate has always been considered good collateral because it needs little monitoring compared to other types of collateral, such as inventory, equipment, and other personal property. ${ }^{90}$ Yet, Wall Street investors have historically viewed mortgages as riskier investments than those assets because they were regulated by a patchwork of local and state laws. ${ }^{91}$ It is in large part because of this aversion that, prior to the $1970 \mathrm{~s}$, all real estate lending, like all politics, was local. ${ }^{92}$ Local lenders lent to local borrowers. ${ }^{93}$ Wall Street had ceded these local mortgage markets to local lenders for these reasons and because of the common belief that local lenders had more insight into local conditions. ${ }^{94}$ This state of affairs was to change with the birth of securitization and the growth of the secondary market.

\section{A. Securitization Explained}

Most simply put, securitization "refers to the aggregation and pooling of assets with similar characteristics in such a way that investors may purchase interests or securities backed by those assets." ${ }^{95}$ A more complex picture of securitization would add the appraisals done to ensure the value of the collateral, the third-party

89. Id.

90. Claire A. Hill, Is Secured Debt Efficient? 80 TEX. L. REV. 1117, 1134 (2002).

91. See LORE \& COWAN, supra note $8, \S 1.11$. They were also viewed as riskier because mortgages were necessarily tied to local economies and a local recession or natural disaster could increase defaults and decrease the value of a pool of geographically concentrated mortgages. Id.

92. See Joseph Philip Forte, Capital Markets Mortgage: A Ratable Model for Main Street and Wall Street, in COMMERCIAL SECURITIZATION FOR REAL ESTATE LAWYERS REAL Estate FinanCE IN THE CAPITAL MARKETS: RISKS AND REWARDS 4-6 (ALI-ABA CLE, 2004) [hereinafter COMMERCIAL SECURITIZATION].

93. Id.

94. See id. at 4-6.

95. SeCURITIZATION, supra note $36, \S 1.01$, at $1-3$; see also Thomas E. Plank, The Security of Securitization and the Future of Security, 25 CARDOzo L. REV. 1655, 1656 n.1, 1657 n. 6 (2004) (providing thorough, albeit not comprehensive, review of securitization literature). The terms "securitization," "asset securitization," and "structured finance" are often used interchangeably. Randall D. Luke \& Louis F. Burke, United States, in SECURITIZATION 205, 205 (David G. Glennie et al. eds., 1998); see also 1 TAMAR FRANKEL, SECURITIZATION $\$ 1.1$, at 3 (1991) (stating that securitization transforms "illiquid debt into securities"). 
credit enhancements offered by entities such as insurance companies, and the complex structures of the securities themselves..$^{96}$

Given this complexity, it is not surprising that the typical investor in a securitized pool is an institutional investor which is purchasing such securities either in the secondary market or through a private placement. ${ }^{97}$ Securitizations are carefully structured to achieve precise tax, accounting and regulatory treatment to make them attractive to such investors. ${ }^{98}$ The net result of the securitization process is that the investors in asset-backed securities come to own "the rights to the present and future economic value of the assets." 99

Typically, securitizations are designed to result in "securities that are of high quality, as evidenced by a high rating, and saleable on the capital markets." 100 The process of securitization thereby allows a firm with a less-than-perfect credit rating to spin off some of its receivables, such as mortgages, into an instrument that is capable of having a higher rating than the firm itself. ${ }^{101}$ An additional benefit of securitization is that it allows investors to manage various forms of risk that are inherent in the underlying receivables. Thus, the underlying credit risk of the receivables can be managed through credit enhancements and due diligence, prepayment risk can be managed through pricing, and litigation risk (bankruptcy consolidation, originator fraud) can be managed by choice of securitization structure. ${ }^{102}$

The basic market requirements for securitizations to thrive are the following: standardized contracts, grading of risk via underwriting, historical statistics of performance of similar assets, standardization of applicable laws, standardization of servicer, quality reliable supply of quality, credit enhancers, and computers to handle the complexity of the necessary analyses. ${ }^{103}$

96. See Claire A. Hill, Securitization: A Low-Cost Sweetener for Lemons, 74 WASH. U. L.Q. 1061, 1073 (1996); see also JOHN FRANCIS HILSON \& JEFFREY S. TURNER, ASSETBASEd Lending: A PRACTICAL GuIDE To SECUREd Financing $§ 2: 6.2$ (2000) (describing various forms of credit enhancements); LORE \& COWAN, supra note $8, \S 1.4$ (identifying typical third-party providers of credit enhancements as banks and insurance companies that offer various complex products to meet the needs of proposed securities issuances).

97. See Hill, supra note 90 , at 1131.

98. Id. at 1130 .

99. SECURITIZATION, supra note $36, \S 1.01$, at 1.3 .

100. Hill, supra note 96 , at 1073.

101. See id.

102. Engel \& McCoy, Wall Street, supra note 32, at 728-39.

103. Leon T. Kendall, Securitization: A New Era in American Finance, in A PRIMER ON Securitization 1, 7 tbl.1.3 (Leon T. Kendall \& Michael J. Fishman eds., 1996). For a discussion on how actuarial data increases credit quality, see Lewis S. Ranieri, The Origins of Securitization, Sources of Its Growth, and Its Future Potential, in A PRIMER ON SECURITIZATION, supra, at 31, 40 (discussing how actuarial information increases credit quality). See also Engel \& McCoy, Wall Street, supra note 32, at 721 ("[S]ubprime securitizations are a fairly new phenomenon relative to their prime counterparts, meaning that the performance of subprime loan pools over time is not yet well understood." (footnote omit- 
Borrowing from Professor Hill, ${ }^{104}$ a typical securitization involves the following steps:

(1) selection ("pooling") of the receivables to be conveyed [by the company originating the transaction (the "originator")];

(2) [creation of a special purpose entity ("SPE") which buys rights to payment from the selected receivables from the originator];

(3) creation of [a second SPE] (the "pool") to which the [rights to the selected] receivables will be conveyed;

(4) establishment of the terms of the securities to be issued by the pool; ${ }^{105}$

(5) conveyance of the receivables [to the pool];

(6) issuance of the pool securities [in a public offering or by private placement];

establishment of mechanisms by which the receivables will be serviced (collected), and the amounts collected held until payment to the pool's securities holders; and

... issuance of the rating agency's rating and the insurer's guaranty. ${ }^{106}$

The conveyance of the receivables through two SPEs is done to protect them from being consolidated with the potential bankruptcy estate of the originator of the pool, which could interrupt the flow of payments to the investors. ${ }^{107}$ This disaggregation of the risk inherent in the receivables and the risk inherent in the issuer lowers the effective cost of a securitization and thereby increases the value of the receivables to the issuer. ${ }^{108}$

Once the securitization is complete, the second SPE uses the proceeds of the issuance to pay the first SPE for the transferred assets, which in turn uses the proceeds to pay the originator. ${ }^{109}$ The inves-

ted)). For a discussion on credit enhancement, see Richard Roll, Benefits to Homeowners from Mortgage Portfolios Retained by Fannie Mae and Freddie Mac, 23 J. FIN. SERVICES RES. 29, 29 (2003) ("It is impossible to overstate the importance of credit enhancement in the process of mortgage securitization, one of the most prominent and striking features of the secondary market.").

104. See Hill, supra note 96 , at 1068.

105. The terms (the interest rate, for instance) of the securities are typically different from the terms of the underlying mortgages. Id. at 1068.

106. See id. at 1077-78.

107. Plank, supra note 95, at 1661-64.

108. See id. at 1662 . This lowering of the cost of securitization effectively comes at the expense of potential creditors of the originator should it file for bankruptcy. See id. at 1657 n.6 (reviewing literature that suggests that securitization is detrimental to the unsecured creditors of the originator and that securitization can be a technique for judgment proofing).

109. Steven L. Schwarcz, Securitization Post-Enron, 25 CARDozo L. REV. 1539, 1540 (2004) (describing the process of securitization). 
tors are repaid over time from the principal and interest payments made by the mortgagors (the borrowers in the underlying loan transactions). ${ }^{110}$ The resulting securities may be either debt or equity securities, depending on the structure of the transaction and the perceived needs of the potential investors. ${ }^{111}$

While an individual securitization of receivables can easily top a billion dollars, ${ }^{112}$ the securitization process is conceptually much the same as any financing or receivables purchase transaction that could be obtained from a bank or finance company. ${ }^{113}$ Indeed, nearly any type of asset with a regular stream of cash payments can be securitized $^{114}$-although certain assets, such as residential mortgages, have turned out to be particularly attractive candidates.

The key attraction of investing in asset-backed securities, as opposed to individual assets, is that it allows an investor to simultaneously choose a narrow type of investment that is likely to meet its investment criteria while (1) reducing due diligence costs by delegating a large portion of such tasks to specialized third parties such as rating agencies; ${ }^{115}$ (2) spreading interest rate, credit, and geographicand sector-concentration risk ${ }^{116}$ over a number of similar assets; (3) reducing the likelihood of interruptions of cash flows by the systemization of cash flows from a large pool of assets; and (4) providing greatly improved liquidity over that of the individual assets that are securitized: ${ }^{117}$

Issuers obviously incur certain transaction costs in securitizations, such as rating agency fees and insurance premiums, that they would not incur by holding the mortgages in their own investment portfolios. ${ }^{118}$ However, securitization also allows for certain costsavings that frequently outweigh the additional costs; indeed, ra-

110. Id.

111. Joseph Philip Forte, Solving the Mortgage Tax Barrier to Defeasance, in COMMERCIAL SECURITIZATION, supra note 92, at 416.

112. See, e.g., WELLS FARGo HOME EQUITY TRUST 2004-1.

113. See HILSON \& TURNER, supra note $96, \S 2: 6.1$, at 2; see also 1 FrANKEL, supra note $95, \S 1.1$, at 4 (arguing that a security is much like a debt, albeit one that is very liquid).

114. Comm. on Bankr. \& Corporate Reorganization of the Ass'n of the Bar of the City of N.Y., Structured Financing Techniques, 50 BUS. LAW. 527, 532 (1995).

115. See Ranieri, supra note 103, at 38 ("Securitization starts to break down as a concept when the issuer imposes on the investor the responsibility of analyzing the underlying collateral.").

116. See Securitization, supra note $36, \S 1.02$, at 1.7 to 1.8 . For instance, by pooling mortgages from across the country, the pool reduces risks associated with changes in local economic conditions as well as risks associated with natural disasters. Id. $\$ 1.02$, at 1.8.

117. See id. \$§ 1.01-.02 (outlining the benefits of securitization); LORE \& COWAN, supra note 8, § 1.19 (same); see also Michael C. McGrath; Structural and Legal Issues in Securiti. zation Transactions, in ASSET-BASED FINANCING 2004, at 609, 612.13 (describing additional benefits of securitization); Alan C. Hess \& Clifford W. Smith, Jr., Elements of Mortgage Securitization, 1 J. REAL EST. Fin. \& ECON. 331, 337-38 (1988) (same).

118. See Plank, supra note 95, at 1668-69. 
tional issuers will only securitize receivables where they believe that the benefits of securitization exceed the transactional costs. ${ }^{119}$

The securitization of residential mortgages, in particular, is attractive to loan originators because these mortgages themselves are not easily traded in a secondary market. ${ }^{120}$ To be attractive to investors, each mortgage would require its own extensive and expensive evaluation and monitoring, as each typically has its own unique terms and risks. These unique characteristics would make mortgages of limited interest on secondary markets that rely on standardization to reduce the transaction costs associated with conveying assets from one party to another. ${ }^{121}$ Since the 1970 s, investors have become quite comfortable investing in residential mortgage-backed securities (RMBS) because the standardization of mortgage terms overcame these problems. ${ }^{122}$ And the securitization of subprime mortgages; in particular, took off when RMBS were designed with characteristics that insulate them from the increased level of credit risk from the underlying subprime mortgage collateral pool. ${ }^{123}$

\section{B. Government-Sponsored Enterprises (GSEs) Create the Secondary Market}

Mortgages have always been bought and sold by investors, but until recently, the secondary market has been an informal arrangement. ${ }^{124}$ The introduction of RMBS changed that: once RMBS are issued, they can be easily traded on the secondary market with comparatively few transaction costs. ${ }^{125}$

The most important factor in the development of the secondary market has been the creation of two government-sponsored enterprises by the federal government: the Federal National Mortgage Association (now known as "Fannie Mae") and the Federal Home Loan

119. Id. at 1669.

120. See Hill, supra note 96, at 1073-74; cf. Peter M. Carrozzo, Marketing the American Mortgage: The Emergency Home Finance Act of 1970, Standardization and the Secondary Market Revolution, 39 REAL PROP. PROB. \& TR. J. 765, 778 (2005) ("Without a standardized mortgage document and uniform lending techniques, the secondary market never would have gotten off the ground.").

121. See Hill, supra note 96, at 1074; see also Eric Bruskin et al., The Nonagency Mortgage Market: Background and Overview, in HANDBOOK, supra note 15, at 5, 20 ("Stan. dardization of loan programs nationwide has been a key element facilitating the development and evolution of today's massive MBS market.").

122. LORE \& COWAN, supra note 8, $\$ 1.11$. RMBS standardization in the 1970s was driven by secondary market purchasing standards set by government-sponsored enterprises. Carrozzo, supra note 120, at 797 (noting that Fannie Mae and Freddie Mac agreed that first order of business was development of standard mortgage).

123. See TEMKIN ET AL.; supra note 49 , at 9-10.

124. Van Order, supra note 35, at 236.

125. Id. 
Mortgage Corporation (now known as "Freddie Mac"). ${ }^{126}$ Indeed, these two entities, along with the Government National Mortgage Association" (GNMA and often referred to as "Ginnie Mae"), have made the U.S. secondary residential mortgage market "the envy of every other country,"128 one that has driven down the cost of mortgage credit for tens of millions of borrowers. ${ }^{129}$ While these entities had created a secondary market for certain loans prior to 1970 , the broad secondary market began in earnest with the passage of the Emergency Home Finance Act of 1970 (EHFA), which allowed GSEs to purchase and securitize conforming mortgages. ${ }^{130}$

In this section, I outline the growth of the secondary market in more general terms. In Part III.C, I take a closer look at the role of GSEs in the creation of the secondary market.

126. Id. Fannie Mae is the oldest of the GSEs, created in the 1930s as a governmentowned secondary market for loans insured by the Federal Housing Administration. Id. At first it operated by issuing its debt and purchasing mortgages that it held in its portfolio. Id. In 1954, it was reorganized to allow private capital to replace federal funds. Lea, His. torical Perspective, supra note 34, at 164. In 1968, it was moved off the federal budget and converted into a GSE. Van Order, supra note 35, at 236. In the 1970s, it switched its focus to conventional loans. Id.

Freddie Mac was formed in 1970 to create a secondary market for the S\&Ls. When it was first created:

[Freddie Mac] dealt only with S\&Ls, and Fannie Mae dealt with mortgage bankers. Now both institutions deal with the same originators. Like Fannie Mae, it is a private GSE and also is off-budget. It initiated the first MBS program for conventional loans in 1971, while Fannie Mae began its conventional MBS program in 1981. Both GSEs' MBS are similar to GNMA's; for example, both protect investors against credit risk but not interest rate risk. . . . Both Fannie Mae and Freddie Mac fund a significant (about $\mathbf{4 0}$ percent) share of their mortgages with debt ....

Id. at 236-37.

\section{Id. at 236.}

GNMA was created in 1968 to handle Fannie Mae's policy-related tasks and to provide a secondary market for government-insured loans. It is on the federal budget as part of the U.S. Department of Housing and Urban Development (HUD).

GNMA was responsible for promoting the major innovation in secondary markets, the MBS. . . . GNMA deals only in federally insured mortgages, primarily those insured by the FHA and the U.S. Department of Veterans Affairs, which account for 10 to 15 percent of the market.

Id.; see Peter J. Wallison \& Bert Ely, Nationalizing Mortgage Risk: The GrowTH of FANNIE MAE AND FREDDIE MAC 7 (2000) (noting that because Ginnie Mae can obtain funds for FHA and VA loan purchases at lower rates than any of its competitors (including Fannie and Freddie), "it faces no competition for these products").

128. Roll, supra note 103, at 29.

129. See Van Order, supra note 35, at 237. Fannie Mae and Freddie Mac have both been rocked by accounting scandals in the last year; as a result, there are calls on many fronts to modify their regulatory status. See, e.g., Stephen Labaton, Limits Urged in Mortgage Portfolios, N.Y. TTMES, Apr. 7, 2005, at C1 (describing attempts to increase oversight over the two companies).

130. See Carrozzo, supra note 120, at 768 (describing the enactment of the EHFA). 
A leading commentator describes two distinct stages in the development of securitization. ${ }^{131}$ The first stage, in the $1970 \mathrm{~s}$, centered on the use of pass-through securities, but pass-through RMBS left prepayment, interest rate, and residual credit exposure risks with investors. ${ }^{132}$ These risks significantly limited the pool of potential investors. ${ }^{133}$ The second stage, which began in earnest in the $1980 \mathrm{~s}$, centered on the division of cash flows and/or credit risk into tranches ${ }^{134}$ that met the specific needs of different classes of investors. ${ }^{135}$

In the late 1970s, "the primary condition" necessary for the explosion of RMBS securitization came about: "a funding shortfall."136 That is, the strong desire for home ownership and the rapid escalation of housing prices created a demand for residential mortgages that the S\&Ls could not meet. ${ }^{137}$ Wall Street firms responded:

[They were] successful over time in changing tax laws to permit the tax-free pass-through of cash flows from home loans to mortgage securities, thereby avoiding double taxation, in modernizing the investment powers of institutional investors and in developing the computer technology needed to create new securities out of cash flows and to track the cash flows. ${ }^{138}$

As investors needed to evaluate the risk of RMBS default, which is a difficult task, specialists stepped forward to provide such services. The privileged raters became preeminent providers of evaluations of the riskiness of mortgage-backed securities. ${ }^{139}$ Thus, the development of credit ratings by agencies such as Standard \& Poor's and Moody's became key elements in the effort to increase confidence that investors had in such securities. ${ }^{140}$ And as investor confidence grew, so did the rating business. ${ }^{141}$

131. See Kendall, supra note 103, at 15-16.

132. Id. Typically, the term "pass-through securities" refers to those securities for which investors are paid out of their percentage ownership share of a securitized pool's cash flow. See HILSON \& TURNER, supra note 96, § 2:6.2, at 2-29.

133. See Kendall, supra note 103, at 15 .

134. A "tranche" is a set of securities secured by a particular pool of collateral that has risk, reward, and/or maturity characteristics that differ from the other tranches secured by the same pool. See JAN JOB DE VRIES RoBBE, STRUCTURED FINANCE § 10:1 (2005).

135. Definition of Nationally Recognized Statistical Rating Organization, 70 Fed. Reg. 21,306 (Apr. 25, 2005) (to be codified at 17 C.F.R. pt. 240).

136. See Kendall, supra note 103 , at 6.

137. Id.

138. Id.; see also Ranieri, supra note 103, at 34 (providing firsthand account of early history of securitization).

139. Louis H. Ederington \& Jess B. Yawitz, The Bond Rating Process, in HANDBOoK of FINANCIAL MARKETS AND INSTITUTIONS 23-3, 23-4 (Edward I. Altman ed., 6th ed. 1987).

140. See LORE \& COWAN, supra note $8, \S 1.11$.

141. See Kendall, supra note 103 , at 14 ("The credit rating agencies welcomed the emergence of ratable securities as a new product line that would increase corporate revenues through new issues and subsequent rating review fees."); Roy C. Smith \& Ingo Walter, Rating Agencies: Is There an Agency Issue?, in RATINGS, RATING AgENCIES AND THE 
The impact of securitization has been so great that it is no exag. geration to say that it is:

one of the most important and abiding innovations to emerge in financial markets since the 1930s. It is changing the face of American and world finance. A revolution has occurred in the way the borrowing needs of consumers and businesses are met. The historic use of financial intermediaries to gather deposits and lend them to those seeking funds is being supplemented and even replaced by securitization processes that bypass traditional intermediaries and link borrowers directly to money and capital markets. ${ }^{142}$

During the 1970s, the primary purchasers of RMBS were Fannie Mae and Freddie Mac as well as the thrifts. ${ }^{143}$ Since the funding shortfall of the late $1970 \mathrm{~s}$, commercial banks, insurance companies, pension funds and mutual funds, among other investors, have become large, frequent and active investors in that market. ${ }^{144}$ Investment in RMBS took off after those institutional investors entered the market: indeed, the RMBS market has increased by more than $500 \%$ from 1984 through the early 2000s. ${ }^{145}$

Starting sporadically in the late 1970s, non-federal-related issuers such as commercial banks and mortgage companies began to issue residential mortgage-backed securities. ${ }^{146}$ These "private label" RMBS are issued without the governmental or quasi-governmental guaranty that a federally related issuer, such as a GSE, would give, and they are typically backed by nonconforming loans. ${ }^{147}$ The development, however, of private label RMBS was "hampered by credit risk concerns." 148 Private label securitization gained momentum during the savings and loan crisis in the early 1980s, when Wall Street firms identified "a unique opportunity to profit from the thrift crisis by proffering the securitization exit strategy as the solution to the thrifts' residential portfolio dilemma." 149

By the 1990s, the types of mortgage-backed securities that were offered in the private-label mortgage market became increasingly complex, moving from single-class mortgage-backed securities to

GLOBal Financlal SySTEM 289, 291 (Richard M. Levich et al. eds., 2002) ("The rating business has grown with the process of financial disintermediation, as bank debt has been replaced by securities issued in one financial market after another ....").

142. Kendall, supra note 103 , at 1 .

143. LORE \& CoWAN, supra note $8, \S 1.3$.

144. Id.; Bruskin, supra note 121 , at 9 (providing the history of nonagency securitization from late 1970 s through mid-1980s).

145. LORE \& COWAN, supra note $8, \S \S 1.3,2.23$.

146. Forte, supra note 92 , at 4-6.

147. See LORE \& CoWAN, supra note $8, \S 2.23$.

148. Forte, supra note 92, at 4-6.

149. Id. 
multiclass Collateralized Mortgage Obligation (CMO) ${ }^{150}$ and Real Estate Mortgage Investment Conduit (REMIC) structures. ${ }^{151}$ Then, starting in the mid-1990s, a significant number of home equity lenders began to securitize their loans as "AAA" MBS.152 The net result of this growth is that "by the end of 2002 more than [fifty-eight] percent of outstanding U.S. single-family residential mortgage debt was financed through securitization." 153

One cannot fully understand the RMBS market without understanding the role of GSEs in creating, stabilizing, and growing that market. So, I now turn to them.

\section{The Ongoing Role of GSEs in the Secondary Market}

Fannie Mae and Freddie Mac participate in the secondary market in two ways: (1) by issuing and guarantying RMBS and (2) by purchasing mortgages and RMBS for their own accounts. ${ }^{154}$ Indeed, they are monstrously large, together having $\$ 1.81$ trillion in assets and $\$ 1.76$ trillion in liabilities at the end of $2003 . .^{155}$ GSEs, as the dominant purchasers of residential mortgages, have effectively standardized prime residential mortgages by promulgating buying guidelines. ${ }^{156}$ Such standardization has led to increases in the liquidity and attractiveness of mortgages as investments to a broad array of investors. ${ }^{157}$ The GSEs themselves have seen their purchases of residential mortgages rise dramatically "from $\$ 69$ billion in 1980 to more than

150. A Collateralized Mortgage Obligation is "a pay-through bond that directs the total payment of principal and interest of the collateral pool to structure different types and maturities of securities in order to meet investor requirements and reduce overall borrowing costs." LORE \& CoWAN, supra note 8, § 3.12.

151. See id. $\S 2.23$. The Tax Reform Act of 1986 allowed CMOs to elect the favored tax status of a REMIC, and "[s]ince 1986, most new CMOs have been issued in REMIC form to create tax and accounting advantages for the issuers." BOND MARKET ASs'N, AN InVestor's Guide to Pass-Through and Collateralized Mortgage Securities 3 (2002), http://www.freddiemac.com/mbs/docs/about_mbs.pdf.

152. Sunil Gangwani, MBS Structuring: Concepts and Techniques, 1 SECURITIZATION CONDUTT 26, 35 (1998).

153. GAO, CONSUMER PROTECTION, supra note 42, at 72; see LORE \& COWAN, supra note $8, \S 1.2$ (listing additional factors in rapid growth of mortgage securitization).

154. See Fannie Mae, The Industry, http://www.fanniemae.com/aboutfm/industry/ indexjhtml (last visited Mar. 10, 2006); Freddie Mac, Our Business, http:/www.freddiemac.com/ corporate/about/what_we_do/business.html (last visited Mar. 10, 2006).

155. Carnell, supra note 7, at 578. As of that date, they also guaranteed $\$ 2.05$ trillion in outstanding MBSs. Id.

156. See id.; infra note 176. Fannie Mae and Freddie Mac have also increased the safety of RMBS investments by offering credit guaranties, "which involves guaranteeing the credit performance of single-family and multifamily loans for a fee." Fannie Mae, Understanding Fannie Mae as a Securities Issuer, http://www.fanniemae.com/mbs/understanding/ index.jhtml (last visited Mar. 10, 2006) (describing mortgage-backed securities).

157. See Raymond A. Jensen, Mortgage Standardization: History of Interaction of Economics, Consumerism and Governmental Pressure, 7 REAL PROP. PROB. \& TR. J. 397, 400 (1972) (noting that Fannie Mae created a task force to identify "substantive mortgage clauses which would be essential to make the [uniform form of] mortgage saleable to investors."). 
$\$ 700$ billion in 1999."158 By 2003, Fannie Mae and Freddie Mac issued $\$ 1.91$ trillion of RMBS, and their total outstanding RMBS amounted to $\$ 3.01$ trillion. ${ }^{159}$ The net result of this growth is that the GSEs' combined share of total bond market debt was 36\% in $2003 .{ }^{160}$

The GSEs' charters restrict the mortgages they may buy. ${ }^{161}$ In general, they must buy loans with loan-to-value ratios of $80 \%$ or less $^{162}$ and may not buy mortgages with principal amounts greater than an amount set each year and fixed at $\$ 359,650$ for a singlefamily home for 2005. ${ }^{163}$ Loans that comply with the restrictions placed on Fannie and Freddie are known as "conforming" loans. Those that do not comply with either of these restrictions are known as "nonconforming" loans. ${ }^{164}$

Fannie Mae and Freddie Mac are now publicly traded corporations, "but they both have nebulous, implicit guarantees, a perception by the financial markets that the [federal] government stands behind their debt, which allows them to borrow (or sell [R]MBS) at interest rates lower than they would otherwise." 165 In return for this guarantee (one not available to any other private secondary market entity) and certain other benefits that Fannie Mae and Freddie Mac were granted, they were expected to grow and stabilize the secondary market, and it is generally agreed that they achieved these goals. ${ }^{166}$ They were also expected to lower the cost of credit for borrowers, al-

158. Van Order, supra note 35, at 236; see also Wayne Passmore et al., GSEs, Mortgage Rates, and the Long-Run Effects of Mortgage Securitization 1 n.2 (Fed. Reserve Bd., Working Paper No. 2001-26, 2001), available at http://ssrn.com/abstract=275008 ("During the $1990 \mathrm{~s}$, their yearly securitization rate is estimated to have fluctuated between 45 percent and 78 percent of conventional conforming mortgage originations.").

159. Carnell, supra note 7 , at 579.

160. Id.

161. Passmore et al., supra note 158 , at 3.

162. Id. This limitation may be lifted if other measures are taken to limit the mortgage's credit risk. $I d$.

163. Holden Lewis, CONFORMING MORTGAGE LOAN LIMITS RISE FOR 2005, BANKRATE, Dec. 3, 2004, http://www.bankrate.com/brm/news/mortgages/20041203a1.asp (stating the annual adjustment is based on the annual increase in the cost of the average house, as measured by the Federal Housing Finance Board).

164. Passmore et al., supra note 158, at 5 ("Most private-sector securitizations are backed by jumbo mortgages or mortgages held by 'sub-prime' borrowers, the bulk of which have blemished credit histories but adequate assets or income to support a mortgage."); Bruskin et al., supra note 121, at 6-7 (identifying major categories of nonconforming loans as jumbos, $\mathrm{B} / \mathrm{C}$ quality (which includes subprime and low-doc and no-doc loans)). Those loans that comply with Fannie Mae and Freddie Mac requirements except for the restriction on loan amount are typically referred to as "jumbo" mortgages. Passmore et al., supra note 158 , at 5 .

165. Van Order, supra note 35, at 237; see also Edward L. Toy, A Credit Intensive Approach to Analyzing Whole Loan CMOs, in HANDBOOK, supra note 15, at 219, 219 ("Fannie Mae and Freddie Mac supported securities are also treated by many as having the equivalent of U.S. government backing.").

166. Passmore et al., supra note 158, at 3 (asserting Fannie Mae and Freddie Mac's "objectives have been largely achieved"). 
though there is significant dispute as to how much they have achieved this goal. ${ }^{167}$

Over half of all residential mortgages are sold into the secondary market. ${ }^{168}$ Of those, Fannie Mae and Freddie Mac now own or securitize more than $80 \%$ of the outstanding stock of single-family mortgages. ${ }^{169}$ The remaining $20 \%$ of the secondary market (other than the portion originated by Ginnie Mae) comes from the "private label" firms, a large component of which is composed of jumbo mortgage securitizations. ${ }^{170}$

Private-label firms are not in a position to compete head on with GSEs because their cost of capital is greater. ${ }^{171}$ Because of this advantage, Fannie Mae and Freddie Mac can price their securities more attractively than private label issuers, and they therefore have nearly the entire "conforming" market to themselves. ${ }^{172}$ The fact that private-label firms cannot compete with GSEs is of key importance in the subprime market, because Fannie Mae and Freddie Mac are beginning to enter it. ${ }^{173}$

Freddie Mac began purchasing subprime loans in 1997, and Fannie Mae began in 1999. ${ }^{74}$ Both "have moved slowly and have limited their purchases to the most creditworthy segment of the subprime market with the most creditworth[iness]." They are believed to own a

167. Id. at 2 (" $[\mathrm{W}] \mathrm{e}$ find that GSEs generally-but not always-lower mortgage rates, particularly when the GSEs behave competitively, because the GSEs' implicit government backing allows them to sell securities without the credit enhancements needed in the private sector.").

168. Van Order, supra note 35, at 237.

169. See Roll, supra note 103, at 32-33 ("Fannie Mae and Freddie Mac have supplied a large part of the growth in demand for mortgage debt via two distinct channels. First, their traditional securitization activity increased in relative importance from 1990 through 1993 and now accounts for roughly $25 \%$ of all mortgage debt. Second, their retained portfolios of directly purchased whole loans and MBSs rose steadily during the past decade from about $5 \%$ to more than $16 \%$ of total mortgage debt.").

170. See Van Order, supra note 35, at 237.

171. Forte, supra note 92, at 4-6; see also WALLISON \& ELY, supra note 127, at 1 ("The lower interest rates that Fannie and Freddie can command because of their government backing permit them to out-compete any private-sector rival and to dominate any market they are permitted to enter."). Fannie Mae and Freddie Mac have a number of other competitive advantages over other RMBS issuers. Carnell, supra note 7, at 580-83; see Passmore, supra note 158 , at 4 .

172. See STANDARD \& POOR'S, PRICING AND PREPAYMENT Characteristics of NONCONFORMING MORTGAGE POOLS 1 (2000). The nonconforming rate is usually twentyfive to fifty basis points higher than the conforming rate. Id.

173. See WALLISON \& ELY, supra note 127, at 8 ("In the past, the GSEs purchased almost exclusively conventional/conforming loans, because those are the best credits available in the middle-class market. But increasingly in recent years-as they have foreseen that their need for assets will outstrip the conventional/conforming market-the GSEs have entered the market for subprime, home equity, and multifamily housing loans."); Van Order, supra note 35, at 236-37.

174. GAO, CONSUMER PROTECTION, supra note 42, at 74 . 
relatively small portion of outstanding subprime securities. ${ }^{175}$ Nonetheless, GSEs have had and will have an extraordinary impact on the subprime secondary market as they become more comfortable operating in the subprime market.

Fannie Mae and Freddie Mac have issued buying guidelines, indicating the types of subprime loans that they are willing to purchase. Given their dominant role in the secondary market, their buying guidelines will likely affect the terms of the mortgages offered by many originators, so as to ensure that Fannie Mae and Freddie Mac are potential buyers of those mortgages. What is most striking about the GSEs' guidelines is that they are much more lenient than those that are found in the privileged raters' pronouncements described below.

The only general category of mortgages regulated by state predatory lending laws that Fannie Mae and Freddie Mac indicated that they would not purchase are "high-cost home loans."176 As we shall see below, the privileged raters, which have far more power than the GSEs to impact the entire subprime market, took a far more conservative approach to loans regulated by state predatory lending laws.

\section{The Role of Rating Agencies in the Securitization of MORTGAGE-BACKED SECURITIES}

All rating agencies derive their power in the secondary market from the value that investors place on the informational content of the ratings that they provide. ${ }^{177}$ Nearly every securitization of mort-

175. Id. Fannie Mae "introduced a new and improved automated underwriting system in 1995 and began to accept higher risk loans. Subsequently, Fannie Mae began to vary some of the terms with the loan's level of risk." Wendy Edelberg, Risk-Based Pricing of Interest Rates in Household.Loan Markets 3 (Fed. Reserve Bd., Working Paper No. 2003-62, 2003), available at http://ssrn.com/abstract $=484522$.

176. Fannie Mae, Announcement 04-06, at 3 (Sept. 28, 2004), http:// www.mortgagebankers.org/resident/2004/fannie-04-06.pdf; Fannie Mae, Announcement 03-12, at 1 (Nov. 21, 2003), http://mbaa.org/resident/2003/fannie03-12.pdf; Fannie Mae, Announcement 03-02, at 1 (Mar. 31, 2003), http://www.mortgagebankers.org/resident/ 2003/fannie03-02.pdf; Letter from Michael C. May, Senior Vice President, Freddie Mac, to All Freddie Mac Sellers and Servicers (Nov. 26, 2003), http://www.freddiemac.com/ sell/selbultn/112603indltr.html. Fannie also indicated that it would not purchase HOEPA "high-cost" home loans and loans with mandatory arbitration clauses. Fannie Mae, Announcement 04-06, supra, at 3-4. Freddie Mac indicated that it would not buy "[m]ortgages originated with single-premium credit insurance; [m]ortgages with terms that exceed either the Annual Percentage Rate ("APR") or the points and fees threshold under the Home Ownership and Equity Protection Act of 1999 ("HOEPA"); or subprime [m]ortgages with prepayment terms that exceed three years." Letter from Michael May to All Freddie Mac Sellers and Services, supra.

177. Many commentators see this rating agency role as the dominant one. See Partnoy, supra note 33, at $633 \mathrm{n} .62$ (cataloging articles arguing that ratings have informational content). Such articles ignore or discount the obvious privileged regulatory status of the NRSROs as well as the consistent finance literature that argues that "credit ratings are of scant informational value." Frank Partnoy, The Paradox of Credit Ratings, in RatiNGs, RATING AgENCIES AND THE GLOBAL FINANCIAL SYSTEM, supra note 141, at 65. 
gage-backed securities is rated by one, and often two, of the three dominant rating agencies. ${ }^{178}$ The rating that the agency provides "is an assessment of the likelihood of timely payment on securities."179 The function of the rating agencies is to reduce "the information asymmetry between issuers of securities and investors."180

The three dominant rating agencies derive additional power because they are granted a privileged status by the Securities and Exchange Commission (SEC) and other financial services regulators. This privileged status results from the incorporation of the privileged raters' ratings into government regulation of other companies. For their labors, the privileged raters are compensated by fees from issuers of securities that solicit ratings from them. ${ }^{181}$

While regulators have incorporated the ratings of the privileged raters into their regulations, the privileged raters themselves are not regulated in any meaningful way. Thus, to the extent that they make systemic mistakes or demonstrate systemic biases, they are not accountable to anyone-unless their failings are significant enough to threaten investor confidence in their work product.

\section{A. How Rating Agencies Rate}

The rating process is typically initiated by or on behalf of a securities issuer. ${ }^{182}$ The issuer then provides the rating agency with informa-

178. See Luke \& Burke, supra note 95, at 221; G. Rodney Thompson \& Peter Vaz, Dual Bond Ratings: $A$ Test of the Certification Function of Rating Agencies, 25 FIN. REV. 457, 457 (1990) (suggesting that typically two ratings significantly decrease the yield of a security, thereby increasing issuer's return); Richard Cantor \& Frank Packer, Multiple Ratings and Credit Standards: Differences of Opinion in the Credit Rating Industry 13 (Fed. Reserve Bank of N.Y., Research Paper No. 9527, 1995), available at http://www.newyork.org/research/ staff_reports/research_papers/9527.pdf (arguing that additional ratings "are likely to be most desirable when the degree of uncertainty about a firm's prospects is large and when the amount of funds to be raised ... is substantial").

179. Schwarcz, supra note 33 , at 6 .

180. Id. at 10; see also Partnoy, supra note 33, at 632 ("Information asymmetry exists in markets where sellers have superior information to buyers about product quality, yet cannot costlessly convey this information to buyers. If buyers are economically rational, prices in a market with information asymmetry will reflect the average quality of a product, and sellers with superior products will bear the cost of the information asymmetry. Consequently, sellers in such a market will have an incentive to disclose the superior nature of their product so that they can receive the highest price." (footnotes omitted)).

181. See GlOBAL CREDIT ANALYSIS, supra note 15, at 52; infra note 209 and accompanying text. For example, the SEC relies heavily upon the services of NRSROs in Rule 3a-7, relating to the 1940 Investment Company Act. See Amy K. Rhodes, The Role of the SEC in the Regulation of the Rating Agencies: Well-Placed Reliance or Free-Market Interference?, 20 SETON HALL LEGIS. J. 293, 345 (1996). Pursuant to Rule 3a-7, "a favorable rating by only one NRSRO of an asset-backed securities issuance exempts the transaction from the regulatory scheme" of that Act. Id. It is in this manner that the NRSRO rating reduces the transaction costs and provides other benefits to issuers of RMBS while also providing a benefit to the NRSRO itself because of the fees that it can charge to the issuer for the rating analysis prescribed by Rule 3a-7.

182. See SECURITIZATION, supra note $36, \S 9.01$, at $9-3$. 
tion regarding the issuer's background, strategy, operations systems, historical performance data, and any other information that may be relevant. ${ }^{183}$ The issuer then typically meets with the rating agency to explain the proposed structure of the deal, the nature of the underlying assets, and the operations of the originator of the assets. ${ }^{184}$

In order to evaluate the "loss potential" of nonagency mortgage pools (nonagency RMBS are those that are not issued by GSEs nor by government agencies, like Ginnie Mae, and are also referred to as private-label RMBS), ${ }^{185}$ rating agencies need to evaluate four key aspects of a securitization transaction: (1) frequency of default, (2) severity of loss given default, (3) pool characteristics, and (4) credit enhancement and the structure of the security. ${ }^{186}$

In order to understand these four key aspects of the transaction, rating agencies conduct four types of analyses: (1) qualitative, (2) quantitative, (3) servicing, and (4) legal risk. ${ }^{187}$

Qualitative Analysis. "Qualitative analysis involves a review of those items that could result in a delay or failure of payment to the investors." 188 A primary concern here is the risk profile of the originator. ${ }^{189}$ The rating agency will also review the assets to be contributed into the collateral pool supporting the securities to be issued to determine, among other things, the predictability of their cash flow. ${ }^{190}$ For real property transactions,

rating agencies review a host of issues relating to the underlying property including, for example, the location and accessibility of the property, the diversity and number of tenants of the property, local and regional vacancy rates and rents, the property's physical condition, the property's management, the terms of the leases of the property's tenants, the credit ratings of the property's principal

183. Id. at 9-4.

184. Id. at 9-3. While RMBS issuers typically solicit a rating, it is also standard practice for Moody's and S\&P to rate a security even where an issuer has not solicited (and paid for) a rating. Such ratings are based solely on public information. Alexander W. Butler \& Kimberly J. Rodgers, Relationship Rating: How Do Bond Rating Agencies Process Information? 1 (EFA 2003 Annual Conference, Paper No. 491, 2003), available at

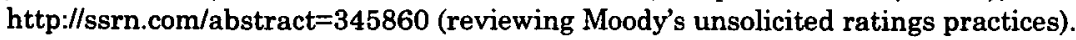

185. Lea, Sources of Funds, supra note 34, at 143.

186. Douglas L. Bendt et al., The Rating Agencies' Approach, in HANDBOOK, supra note 15, at 191, 192; see Plank, supra note 95, at 1667 n.42 ("For example, if securities backed by a pool of receivables need loss coverage or credit enhancement equal to seven percent of the original principal balance of the receivables to achieve the desired rating, this loss coverage could be in the form of additional collateral: An issuance of $\$ 100$ million of debt securities backed by a pool of $\$ 107$ million receivables ....").

187. SECURITIZATION, supra note $36, \S 9.01$, at 9-5.

188. Id.

189. Id. at $9-6$.

190. Id. 
tenants, the strength of the local economy, and possible hazards (such as earthquakes), among other things. ${ }^{191}$

Quantitative Analysis. Quantitative analysis involves a review of the cash flow aspects of the transaction. ${ }^{192}$ This quantitative analysis is a key part of valuating the collateral and determining the credit enhancement levels; it also is key to determining "the sizing of the principal amount of the securities to be issued" and determining whether the issued securities will be able to make timely payment of the rated securities. ${ }^{193}$

Underwriting Criteria and Servicer Characteristics. Rating agencies review the originators' underwriting criteria as well as the capabilities of the servicers of the loans that are placed within the pool. ${ }^{194}$ Rating agencies will review individual loans to ensure that they comply with the originators' stated underwriting criteria. ${ }^{195}$ The rating agency will independently review the servicer when the originator is not acting as servicer; this is undertaken to evaluate the risk of delays in payments due to operational problems of the servicer or its own credit problems. ${ }^{196}$

Legal Analysis. Legal analysis involves a review of the legal risks associated with the proposed transaction. ${ }^{197}$ These legal risks, also called "litigation risks," include the risk that RMBS investors will be liable for violations of predatory lending laws by the originators of the mortgages in any given RMBS pool. ${ }^{198}$ Other legal risks evaluated by the rating agencies include the following:

191. Id.

192. Id.

193. Id.; see also GLOBAL CREDIT ANALYSIS, supra note 15, at 470 ("Accounting for the potential variability of collateral losses is important in the structured finance rating process because more variable pool losses, with constant expected pool losses, generally implies higher expected losses for investors.").

194. SECURITIZATION, supra note $36, \S 9.01$, at 9-11; Schorin et al., supra note 79 , at 83 ("Loan servicers who have extensive experience with $\mathrm{A}$ borrowers have found that their expertise in that arena does not necessarily, or even generally, carry over into the $B$ and $C$ sector. The cost of servicing $B$ and $C$ loans could easily double that of servicing A loans.").

195. SECURITIZATION, supra note $36, \S 9.01$, at $9-11$.

196. Id.; Bruskin et al., supra note 121, at 29 ('Many of the servicer's functions are critical to the credit quality of a transaction. In addition to collecting the monthly payments and passing the cash flows to the trustee, the servicer handles delinquent loans, initiates foreclosure procedures, and liquidates properties when necessary.").

197. SECuRITIZATION, supra note $36, \S 9.01$, at $9-10$.

198. See Engel \& McCoy, Wall Street, supra note 32, at 723 ('Litigation risk is the possibility that borrowers will bring predatory lending claims or, when charged with nonpayment, raise predatory lending defenses against the trusts that own their loans."); LORE \& COWAN, supra note $8, \S 9.6$ ("Another legal consideration that can be expected to affect the rating of a mortgage-backed security relates to what legal remedies and procedural rules are available to the issuer under state and local laws to enforce mortgage loan covenants, particularly upon default in payment of principal and interest of the mortgages. Usury statutes may operate to limit enforcement of interest rate provisions of mortgage loans in default; foreclosure laws (such as homestead laws and statutory rights of redemption) and local procedural rules may 

the effects of a bankruptcy of the issuer on the structure and cash flows, ${ }^{199}$
the regulatory issues of the issuer/industry, the legal structure of the sale (that is, true sale or a loan),
the requirements necessary for a perfection of secu- rity interests,
contractual restrictions (such as negative pledge covenants), and
the tax implications on the Special Purpose Entity and investors. ${ }^{200}$

This Article focuses on the legal risk that investors in an RMBS pool will be held liable for violations of predatory lending laws by the originators of the mortgages in any given pool.

\section{B. The Dominant Rating Agencies Enjoy Privileged Regulatory Status as Nationally Recognized Statistical Rating Organizations}

For the purposes of this Article, the term "privileged regulatory status" refers to the role of the privileged raters as gatekeepers to other private financial entities which are attempting to access the financial markets. ${ }^{201}$ This status results from the favorable treatment

prevent the holder from obtaining title to property securing defaulted mortgage loans in a timely manner; and anti-deficiency laws effectively may preclude the possibility of timely resale of foreclosed property by the issuer. Additional protection may be required to achieve a desired securities rating, depending upon the terms of the collateral instruments and the jurisdictions where the mortgaged properties are located.").

199. Historically, "[t]he main legal and regulatory considerations in structured financings are concerned with the potential insolvency of the issuer or other participants in the transaction." GLOBAL CREDIT ANALYSIS, supra note 15, at 497.

200. See David W. Forti \& Blasé B. Iaconelli, Commercial Mortgage-Backed Securities and the Rating Agency Process, in SECURITIZATIONS: LEGAL AND REGULATORY Issues § 19.05 (Patrick D. Dolan \& C. VanLeer Davis III eds., 2005).

201. Richard Cantor, Moody's Investors Service Response to the Consultative Paper Is. sued by the Basel Committee on Bank Supervision "A New Capital Adequacy Framework," 25 J. BANKING \& FIN. 171, 179 (2001) ("By using ratings as a tool of regulation, regulators fundamentally change the nature of the rating agency product. Issuers pay rating fees, not to facilitate access to the capital market, but to purchase a privileged status for their securities from the regulator. As a result, licensed rating agencies will have a product to sell regardless of the analytic quality of their ratings and their credibility with the investor community."); Schwarcz, supra note 33, at 2 ("To a large extent, the almost universal demand by investors for ratings makes rating agencies gatekeepers of the types of securities that investors will buy. ... This unprecedented power, combined with their de facto control over international debt markets, makes the issue of whether rating agencies should remain unregulated more urgent." (footnotes omitted)); see Paul Robbe \& Ronald Mahieu, Are the Standards Too Poor?: An Empirical Analysis of the Timeliness and Predictability of Credit Rating Changes 1 (Jan. 31, 2005) (unpublished manuscript), available at http://ssrn.com/abstract=648561 ("In the United States, banks and other financial institutions have only been allowed to hold bonds of investment grade quality (i.e., bonds that are rated $B B B$ - or better) ever since 1936 . As a consequence, having a credit rating has become a necessity in order to acquire external debt capital."). 
that government regulators grant to securities issued by private companies and other entities that are highly rated by the privileged raters. This privileged regulatory status is granted by various government bodies in exchange for the quasi-public responsibilities the privileged raters take on by providing ratings to the investment community but is not paired with any commensurate monitoring of the privileged raters themselves. Thus, the privileged raters themselves are privileged because regulators have incorporated the service (ratings) that they sell into the regulatory structure of the capital markets. In addition, the investment-grade ratings that the privileged raters issue are themselves equivalent to a "regulatory license" that confers a significant financial benefit on its recipient. ${ }^{202}$

Rating agencies have been actively rating securities in the United States since the beginning of the twentieth century. ${ }^{203}$ The main source of the privileged regulatory status of the privileged raters, that select subset of rating agencies, derives from the SEC, which had granted them (or their predecessors-in-interest) nationally recognized statistical rating organization status (an NRSRO) in 1975. ${ }^{204}$ NRSRO status initially referred to those rating agencies whose ratings could be used in implementing the net capital requirements for broker-dealers, the first instance of a high rating by a rating agency resulting in favorable regulatory treatment. ${ }^{205}$ At that time, the SEC essentially grandfathered three rating agencies: Fitch, Moody's and Standard \& Poor's. ${ }^{206}$

Currently, a credit rating agency must request a no-action letter (the means by which the SEC makes a case-by-case regulatory determination) from the SEC before that agency attains NRSRO status, presumably until that agency ceases to exist. ${ }^{207}$ While six such noaction letters have been granted by the SEC since 1975 , only five NRSROs remain due to consolidation: A.M. Best Company, Inc. ("A.M. Best"), Dominion Bond Rating Service Limited (DBRS), Fitch, Inc. ("Fitch"), Moody's Investors Service, Inc. ("Moody's"), and the Standard \& Poor's Division of the McGraw Hill Companies, Inc.

202. Frank Partnoy uses the term "regulatory license" to describe "the valuable property rights associated with the ability of a private entity, rather than the regulator, to determine the substantive effect of legal rules." Partnoy, supra note 33, at 623.

203. See Rhodes, supra note 181, at 300-02 (discussing the growth of rating agencies in the United States).

204. Hill, supra note 33 , at 44 ; see Rhodes, supra note 181 , at $321-22$; see also Schwarcz, supra note 33, at 5 ("Rule 3a-7 of the Investment Company Act of 1940 exempts certain financings from registration and compliance with that Act if, among other requirements, the securities are rated 'investment grade' by at least one NRSRO.").

205. Rhodes, supra note 181 , at 321 .

206. Id.

207. Definition of Nationally Recognized Statistical Rating Organization, 70 Fed. Reg. 21,306, 21,307-08 (Apr. 25, 2005) (to be codified at 17 C.F.R. pt. 240). 
("Standard \& Poor's"). ${ }^{208}$ The first two are very small and have only a tiny impact on the RMBS market. ${ }^{209}$

The SEC did not define an NRSRO in $\mathbf{1 9 7 5}$ and has intermittently attempted to do so since then. ${ }^{210}$ The lead-up to the current rule proposal to define the term NRSRO began when the SEC issued its "1994 Concept Release" requesting comments on the Commission's use of NRSRO ratings. ${ }^{211}$ The 1994 Concept Release was followed by a "1997 Rule Proposal" to define the term NRSRO. ${ }^{212}$ The proposal would have established a formal application process for recognizing NRSROs in lieu of the no-action letter process. ${ }^{213}$ The 1997 Rule Proposal continued the reliance on market-based acceptance of a rating agency through a criteria requiring national recognition "by the predominant users of securities ratings." 214 However, the SEC did not act upon the proposal, and by 2002 the Senate Committee on Governmental Affairs launched investigations into the Enron collapse that questioned why the NRSROs had "continued to rate Enron a good credit risk until [only] four days before the firm declared bankruptcy."215

Additionally, in November 2002 the SEC conducted public hearings on the use of credit rating agencies in the U.S. securities mar-

208. Id.; see also Letter from Kent Wideman, Group Managing Dir., Dominion Bond Rating Ser. Ltd., to Jonathan G. Katz, Sec'y, SEC 1 (June 10, 2005), http://www.sec.gov/ rules/proposed/s70405/dbrs061005.pdf; Letter from Larry G. Mayewski, Executive Vice President \& Chief Rating Officer, A.M. Best Comp., Inc., to Jonathan G. Katz, Sec'y, SEC 1-2 (June 9, 2005), http://www.sec.gov/rules/proposed/ s7.0405/ambestco060905.pdf.

209. Dominion Bond Rating Service Limited was recently granted NRSRO status on February 23, 2003. See Letter from Kent Wideman to Jonathan G. Katz, supra note 208, at 1. A.M. Best specializes in ratings of insurance-related organizations. See A.M. Best Company, Best's Ratings and Analysis, http://www3.ambest.com/ratings/default.asp (last visited Mar. 10, 2006). The Egan-Jones Ratings Company has been the most forceful of the currently nonNRSRO rating agencies in pressing the SEC to grant it NRSRO status, but it has not prevailed as of yet. See Letter from Sean J. Egan \& W. Bruce Jones to Jonathan G. Katz, Sec'y, SEC 3 (Nov. 10, 2002), http://www.sec.gov/news/extra/credrate/eganjones2.htm.

210. Definition of Nationally Recognized Statistical Rating Organization, 70 Fed. Reg. $21,306,21,307$.

211. Id. at 21,308 (discussing the recent attempts to define the term NRSRO and the process by which credit rating agencies are designated NRSROs); see also SEC, REPORT ON THE Role and Function of CRedit Rating agencies In the Operation of the Securities MARKETS 10-25 (2003), http://www.sec.gov/news/studies/credratingreport0103.pdf [hereinafter SEC, REPORT] (describing the use of NRSRO ratings in government regulations and legislation).

212. Capital Requirements for Brokers or Dealers, Exchange Act, Release No. 34-39457, 62 Fed. Reg. 68,018 (proposed Dec. 30, 1997); see also SEC, REPORT, supra note 211, at 12-15.

213. See SEC, REPORT, supra note 211 , at 13.

214. See id. Other criteria included organizational structure, adequate staffing, financial resources, use of systematic procedures to ensure credible and accurate ratings, contacts with the management of issuers, and internal procedures to prevent misuse of nonpublic information. Id. The rule asked for comments on prohibition of charging issuers fees based upon the size of a transaction, whether a time period should be required for action on an application for an NRSRO designation, whether NRSROs should make their ratings publicly available, whether objective criteria should be used for NRSRO recognition, and whether statistical models could serve as substitutes for NRSRO credit ratings. Id. at 13-15.

215. Id. at 16 . 
kets. ${ }^{216}$ Furthermore, in January of 2003 the SEC submitted a report required by the Sarbanes-Oxley Act of 2002 on the role and function of rating agencies that addressed the outstanding issues from the 1997 Rule Proposal and the 2002 hearings. ${ }^{217}$ In June, the SEC issued the 2003 Concept Release "seeking comment on a number of issues relating to credit rating agencies." ${ }^{18}$ Among many other issues, most commenters supported the concept of regulatory oversight of NRSROs to determine whether an agency continues to meet the NRSRO criteria on an ongoing basis. ${ }^{219}$ Internationally, in December 2004, the Technical Committee of the International Organization of Securities Commissions (IOSCO) published a "Code of Conduct Fundamentals for Credit Rating Agencies" that provided a voluntary code of conduct for rating agencies that addressed how to manage or eliminate conflicts of interest, help prevent misuse of nonpublic information, and protect agency analytical independence. ${ }^{220}$

In 2005 , the SEC has again released a rule proposal to define NRSRO. ${ }^{221}$ In the proposed new definition, the Commission stated "An entity that meets the proposed definition would be an NRSRO," clearly describing a self-designating process, absent affirmative Commission action. ${ }^{222}$ The Commission's proposal also notes that its staff will be available to provide no-action letters as appropriate to rating agencies that choose to seek them..$^{223}$

Public response regarding a renewal process for NRSRO no-action letters has varied as to whether requiring a renewal of NRSRO status is a positive development. Unsurprisingly, Standard \& Poor's found a renewal requirement for existing NRSROs to be an additional, unneeded cost because of a potential agreement between ex-

216. Id. at 18. Topics addressed included (1) the current role and functioning of rating agencies, (2) informational flow in the rating process, (3) concerns regarding potential conflicts of interests or abusive practices, and (4) the regulatory treatment of rating agencies, including concerns regarding barriers to entry. Id. at 21-25.

217. Id. at 3-4.

218. Definition of Nationally Recognized Statistical Rating Organization, 70 Fed. Reg. 21,306, 21,309 (Apr. 25, 2005) (to be codified at 17 C.F.R. pt. 240).

219. Id. at 21,309-10.

220. Id. at 21,310; see TECHNICAL COMM. OF THE INT'L ORG. OF SEC., CODE OF CONDUCT FUNDAMENTALS FOR CREDIT RATING AGENCIES (2004), http://www.bafin.de/internationales/ iosco/cc_0410.pdf.

221. Definition of Nationally Recognized Statistical Rating Organization, 70 Fed. Reg. 21,306 .

222. Id. at 21,318; see also Letter from Charles S. Morrison, Money Mkt. Group Leader, Fid. Mgmt. \& Research Co., to Jonathan G. Katz, Sec'y, SEC (June 23, 2005), http://www.sec.gov/ rules/proposed/s70405/s70405-8.pdf; Letter from Amy B.R. Lancellotta, Senior Counsel, Inv. Co. Inst., to Jonathan G. Katz, Sec'y, SEC 2-3 (June 9, 2005), http://www.sec.gov/rules/proposed/s70405/ici060905.pdf.

223. Definition of Nationally Recognized Statistical Rating Organization, 70 Fed. Reg. $21,306,21,318$. In addition, due to the possibility of "changing market conditions," the SEC proposal calls for the staff to include "expiration dates" in NRSRO no-action letters that it issues. Id. at 21,319 . 
isting NRSROs and the Commission to require a detailed compliance report on an ongoing basis. ${ }^{224}$

On the other hand, the Investment Company Institute agrees that no-action letters should only be granted for a specified period of time, after which a renewal process or otherwise reconsideration of the agency should be required in order to ensure the NRSRO still satisfies the criteria necessary for such status. ${ }^{225}$ The Association for Financial Professionals also supports expiration dates on no-action letters through periodic reviews to ensure that NRSROs continue to meet the initial recognition criteria no less than every five years. ${ }^{226}$ The Society of Corporate Secretaries and Governance Professionals supports an annual affirmation by the NRSRO that it continues to meet the definitional requirements. ${ }^{227}$

The fact that the pool of NRSROs was capped is of great significance because in order to be sold, residential mortgage-backed securities must have a rating from one or more of them. ${ }^{228}$ This is because financial institutions that purchase asset-backed securities require the rating "to satisfy applicable regulatory requirements, investment guidelines, covenant restrictions [and/]or internal policies." 229 Indeed, "[a]s a practical matter, securitizations cannot be completed without rating agency approval." 230

Since the SEC anointed the chosen NRSROs in 1975, federal and state financial regulators have "found that ratings may serve a variety of uses." ${ }^{231}$ The current regulatory environment "requires or encourages various entities-broker-dealers, banks, money-market funds, insurance companies, trust companies, pension funds, and

224. See Letter from Kathleen A. Corbet, President, Standard \& Poor's, to Jonathan G. Katz, Sec'y, SEC 13 (June 9, 2005), http://www.sec.gov/rules/proposed/s70405/ standardpoors060905.pdf. No additional information regarding this "framework" is available. The Dominion Bond Rating Service states that the NRSRO designation "should remain in effect unless and until it is withdrawn for cause." Letter from Kent Wideman to Jonathan Katz, supra note 208, at 9 (emphasis added).

225. Letter from Amy Lancellotta to Jonathan Katz, supra note 222, at 2-3.

226. Letter from James A. Kaitz, President \& CEO, Ass'n for Fin. Prof., to Jonathan G. Katz, Sec'y, SEC 6 (June 7, 2005), http://www.sec.gov/rules/proposed/s70405/afp060705.pdf.

227. Letter from Sec. Law Comm., Soc'y of Corp. Sec'ys and Governance Prof., to Jonathan G. Katz, Sec'y, SEC 3 (June 2, 2005), http://www.sec.gov/rules/proposed/ s70405/slcsesgp060205.pdf.

228. See Luke \& Burke, supra note 95, at 221.

229. Id.; see Partnoy, supra note 33, at 690 ("[C]redit ratings have been incorporated into hundreds of rules, releases, and regulations, in various substantive areas, including securities, pension, banking, real estate, and insurance regulation."); Rhodes, supra note 181 , at $314 \mathrm{n} .116$ (cataloging statutory and regulatory references to ratings).

230. Luke \& Burke, supra note 95, at 221 ; see Kendall, supra note 103, at 4 ("Since most securitized assets are sold with double-A or triple-A ratings from a national creditrating agency, the rating agencies are involved in the securitization process.").

231. GLOBAL CREDIT ANALYSIS, supra note 15, at 59; see Partnoy, supra note 33 , at 690 . 703 (listing eight places in the U.S.C. and references 60 places in the C.F.R. where NRSRO status is referenced). 
many others-to purchase financial instruments rated investment grade" by an NRSRO. ${ }^{232}$ While the NRSROs thereby bestow significant regulatory benefits upon issuers of securities, they themselves "are not subject to substantive monitoring." ${ }^{233}$ The privileged raters have been described as operating a "regulation-induced oligopoly." ${ }^{234}$ The privileged raters have been criticized for a range of wrongs that relate both to their function as providers of information and to their privileged regulatory status. Many of these criticisms appear warranted, although it is unclear how they can be resolved.

The most vehement criticism is that the privileged raters do not provide accurate and valuable information to the markets. The most commonly cited evidence of this is that the privileged raters often disagree in their ratings. ${ }^{235}$ One rating agency critic has noted that it is unclear "what kind of information rating agencies intend to summarize" and whether ratings "efficiently aggregate this information."236 At a minimum, the financial markets perceive Standard \& Poor's and Moody's "as conservative, and comparably so, in their ratings practices. Indeed, there is some empirical evidence that the two have become more conservative over the years." 237

One leading rating agency scholar argues that the privileged raters have survived not:

because they produce credible and accurate information. They have not maintained good reputations based on the informational content of their credit ratings. Instead, the credit rating agencies have thrived, profited, and become exceedingly powerful because they have begun selling regulatory licenses, [that is], the right to be in compliance with regulation. Credit ratings therefore are an excellent example of how not to privatize a regulatory function.

232. Hill, supra note 33, at 44; see Partnoy, supra note 33, at 692 n. 349 (charting history of increasing use of ratings in legislation and regulation).

233. Hill, supra note 33, at 44.

234. Butler \& Rodgers, supra note 184 , at 16 ; see William H. Beaver et al., Differential Properties in the Ratings of Certified vs. Non-Certified Bond Rating Agencies 8 (Sept. 2004) (unpublished manuscript), available at http://ssrn.com/abstract=596626 ("Moody's is protected from most competition and is practically guaranteed business by virtue of legal requirements for all public bond issuances to be rated by an NRSRO.").

235. See, e.g., Larry G. Perry, The Effect of Bond Rating Agencies on Bond Rating Models, 8 J. FIN. RES. 307, 313 (1985) (noting that S\&P and Moody's disagree fifty-eight percent of the time).

236. Gunter Löffler, An Anatomy of Rating Through the Cycle, 28 J. BANKING \& FIN. 695, 695-96 (2004) ("[T]here is plenty of academic and anecdotal evidence which suggests that agency ratings do not fully reflect available information."); Perry, supra note 235, at 307 ("One of the problems associated with predicting bond ratings is that the rating services often disagree when assigning ratings. Since the rating is a reflection of the risk, which affects price, rating errors can affect investors and the issuing firms.").

237. Hill, supra note 33, at 44; see also Schwarcz, supra note 33, at 22 ("[T] he rating agency system, as presently constituted, is conservatively biased against innovation."). 
Those who advocate privatizing other regulatory functions should heed this warning. ${ }^{238}$

\section{Ratings by the Privileged Raters Are Biased Against the Public Interest}

Privileged raters claim to sell their independent judgment. In the words of a senior Moody's employee, "it is widely recognised that a rating agency and its analysts should be independent-not subject to influence by interested market forces, such as financial intermediaries, governments, or issuers themselves."239 But it appears that NRSRO ratings are subject to biases that are not consistent with the public interest. This is borne out both by empirical research as well as by admissions of NRSRO employees.

A recent study (the "Beaver Study") has demonstrated that Moody's approach to ratings is (and has suggested that all NRSRO ratings are) conservative when compared to that of the Egan-Jones Ratings Company, a credible non-NRSRO rating company. ${ }^{240}$ The Beaver Study argues that there is an incentive for privileged raters to "be more conservative because there is greater cost to losses due to overvalued assets than foregone gains because of undervaluation" and that this incentive results from their quasi-regulatory role. ${ }^{241}$ For the purposes of the Beaver Study, this means that NRSRO ratings are "more stable to minimize unnecessary consequences." 242

While the conservatism found in the Beaver Study was related to the timing and frequency of rating changes by Moody's, the Beaver Study offers evidence that privileged raters are quasi regulators mindful of the impact their gatekeeping function has on the capital

238. Partnoy, supra note 33, at 711; see Dieter Kerwer, Standardising as Governance: The Case of Credit Rating Agencies 3 (MPI Collective Goods, Preprint No. 2001/3, 2001), available at http://ssrn.com/absract=269311 ("[D]espite the fact that rating agencies have become increasingly influential in global financial markets, it is very hard to hold them accountable for their action: rating agencies almost never have to justify their decisions, let alone provide compensation to others for the adverse consequences of their mistakes.").

239. GLOBAL CREDIT ANALYSIS, supra note 15, at 52.

240. Beaver, supra note 234, at 5. In particular, the Beaver Study found that EganJones provided more timely and accurate information when changing ratings. Id.; see also Robbe \& Mahieu, supra note 201, at 28 (finding that ratings are accurate but not timely).

241. Beaver, supra note 234, at 2. The Beaver Study compared the performance of NRSROs with another reputable non-NRSRO rating agency, Egan-Jones Rating Company, and found that Egan-Jones provided more timely and accurate information when changing ratings. Id. The study could not conclude that the difference is attributable to a conflict of interest by the privileged raters. It attributed the difference to the privileged raters' conservative approach to ratings changes. Id. at 3-4. In contrast to the privileged raters, EganJones charges investors, rather than issuers, for its services. Thus, it has an incentive to provide investors with timely information. Regardless of whether the NRSROs' bias is consciously attributable to their issuer-paid fee business model, the ratings are inaccurate consistent with their clients' best interest and not those of investors.

242. Id. at 2. This contrasts with the Egan-Jones ratings which are generally more timely and more responsive to new information. Id. at 3 . 
markets. In addition, the privileged raters take that impact into account, demonstrably more so than Egan-Jones, when setting their ratings policy. In other words, they are not merely providers of independent information but are also quasi regulators subject to institutional pressures. ${ }^{243}$

In addition to this empirically demonstrated bias, the privileged raters often describe themselves as "advocate[s]" for investors. ${ }^{244}$ Indeed, Standard \& Poor's has made this point explicitly in the context of antipredatory lending laws: "Absent clarity on these issues, in order to best protect investors in rated securities, Standard \& Poor's may adopt a conservative interpretation of an antipredatory lending law and may, in instances where liability is not clearly limited, exclude mortgage loans from transactions it rates." 245

While it is unclear the extent to which privileged rater biases impact their predatory lending law guidelines, it is clear that their ratings policies are not the independent Delphic pronouncements that they represent them to be. And their treatment of state predatory lending laws, particularly when contrasted with that of the GSEs, shows how the privileged raters benefit investors at the expense of subprime borrowers. This offers a case study of how the public interest suffers from the biases of the privileged raters.

As discussed in Part VI.C below, the privileged raters, whether driven by bias or merely by their own mandate to protect investors first and foremost, have come to control a veto over state legislators who are attempting to stop predatory lending in their jurisdictions. This veto by unelected, unaccountable, profit-driven corporations is highly disturbing, to say the least.

\section{PRIVILeged Raters Gut Strong State Predatory Lending LEGISLATION}

In 2004, New Jersey felt compelled to amend one of its premier consumer protection laws, the Home Ownership Security Act, even

243. Egan-Jones argues that one such form of institutional pressure results from the compensation structure that privileged raters have developed: "If rating firms are dependent on issuers for support, they will bow to the wishes of those issuers . . . " Letter from Egan-Jones Ratings Comp. to Jonathan G. Katz, Sec'y, SEC 1 (May 26, 2005), $\mathrm{http}: / / \mathrm{www}$. sec.gov/rules/proposed/s70405/eganjones052605.pdf. While there is no empirical evidence that the privileged raters have succumbed to such pressure in the development of their predatory lending legislation guidelines, it is also unquestionably true that the interests of the privileged raters and issuers of RMBS both benefit from less state regulation and from a strong holder in due course doctrine.

244. See SECURITIzaTION, supra note $36, \S 9.01$, at 9-3.

245. Promoting Home Ownership by Ensuring Liquidity in the Subprime Mortgage Market: Joint Hearing Before the Subcomm. on Financial Institutions and Consumer Credit and the Subcomm. on Housing and Community Opportunity of the H. Comm. on Financial Services, 108th Cong. 14 (2004) (statement of Frank Raiter, Managing Director, Standard \& Poor's Credit Market Services) (emphasis added). 
though it was enacted with broad partisan support only one year prior. ${ }^{246}$ The New Jersey law was designed to control a small number of unscrupulous brokers and lenders that originate predatory loans. ${ }^{247}$ That same year, Georgia found itself doing the same thingamending its own antipredatory lending law, the Fair Lending Act, that it had enacted mere months before. ${ }^{248}$

These changes are cause for great concern as they were driven in large part by the privileged raters which had decided, in effect, that the laws had to change. And change they did. The privileged raters, which promote themselves as no more than information-analyzing handmaidens to the invisible hand of the market, have taken it upon themselves to prevent states from regulating in their traditional spheres of authority: mortgage and consumer protection laws. ${ }^{249}$ As a result of these actions by the privileged raters, the judgment about the suitability of such laws is becoming less and less the domain of the duly elected representatives of state citizens; rather, it has shifted into the domain of financial services firms that are advocates for investors, not the public.

Standard \& Poor's, Moody's and Fitch each have their own approach to rating RMBS pools, but they all pay particular attention to the impact of predatory lending statutes on such pools. All of the privileged raters review such statutes in order to determine whether they are (1) ambiguous, (2) allow for assignee liability, ${ }^{250}$ and (3) allow for unquantifiable damages. ${ }^{251}$

While the privileged raters differ in their approaches to assessing the risk in the RMBS market, they eventually arrived at similar conclusions regarding antipredatory lending laws. The privileged raters rate RMBS transactions by categorizing each state statute based upon the nature and degree of the assignee liability and damages provisions of its antipredatory lending law. Based on those evaluations, the privileged raters decide whether the transaction can be rated and, if it can be rated, how much credit enhancement is necessary to achieve the desired rating. In states where there is both assignee liability and unquantifiable damages, some of the privileged raters have refused to rate transactions containing mortgage loans from such jurisdictions. ${ }^{252}$ Moreover, they have determined that the

246. See infra Part V.F.

247. See id.

248. See infra Part V.D.

249. See Engel \& McCoy, Wall Street, supra note 32, at $723 \mathrm{n} .12$ ("The ratings agencies have interposed themselves as the ultimate arbiters of these laws by refusing to rate subprime RMBS in jurisdictions whose assignee liability provisions they deemed too harsh.").

250. That is, the law allows for liability for a wrong perpetrated by the originator of a note to attach to an assignee of the note.

251. See infra Parts V.B, V.D-F.

252. See infra Parts V.D-F. 
legal risks in certain states (as well as in certain municipalities that have enacted antipredatory lending legislation) require that RMBS transactions either bar loans originating from such jurisdictions, or if a pool does contain loans from such jurisdictions, the privileged raters implement expensive credit enhancements to achieve the ratings desired by the securitizers of such pools. ${ }^{253}$ That is, these actions can effectively shut down the entire mortgage market of a state that passes strong predatory lending legislation.

A result of the privileged raters' analysis has been that they have pushed states to standardize their predatory lending laws. This standardization benefits secondary market players because it reduces their risks and tends to increase the size of the RMBS market by reducing transaction costs. However, unlike the standardization that took place in the prime market in the $1970 \mathrm{~s}$, this standardization is not implemented with the needs of homeowners in mind. The evidence of this is clear from the discussion that follows in this Part regarding the Georgia and New Jersey predatory lending laws. It is also clear that key players in the more than twenty other states that passed predatory lending legislation watched the interplay between the privileged raters and these two state governments ${ }^{254}$ and modified their own bills to comply with the standardization that the privileged raters imposed in those two cases.

\section{A. The Home Ownership Equity Protection Act Provides Limited Protection}

In addition to state predatory lending laws, there have been many attempts to respond to the explosion of predatory lending. State attorneys general have initiated lawsuits, ${ }^{255}$ regulators have taken

253. See infra Part V.F.

254. See, e.g., Diane Velasco, Others Have Tried Something Similar, AlbuqUERQUE J., Jan. 26, 2004, at 9 (noting that a spokesman for ACORN, which was instrumental in drafting New Mexico's predatory lending legislation, stated that "[d]uring the last (legislative) session, we made sure that the [secondary market's] problems with the Georgia law were not duplicated in the New Mexico law so we wouldn't have the same difficulties"); see also Jack Milligan, Learning the Hard Way, MORTGAGE BANKING, Sept. 2004, at 26, 32 ("There are three important lessons that can be learned from the Georgia experience, and states that have yet to pass their own predatory lending law would do well to pay heed."). For a thorough review of the legislation in those other states, see Azmy, supra note 5, at 361-78. See also Giang Ho \& Anthony Pennington-Cross, The Impact of Local Predatory Lending Laws (Fed. Reserve Bank of St. Louis, Working Paper No. 2005-049A, 2005), available at http://ssrn.com/abstract=761106 (quantifying differences among predatory lending laws).

255. In one such settlement, coordinated by over a dozen state attorneys general, Household International and its affiliates, all major mortgage lenders, agreed to pay tens of thousands of borrowers up to $\$ 484$ million. Michael Slackman, Borrowers to Share Mortgage Settlement, N.Y. TMMES, Aug. 5, 2003, at B4, available at 2003 WLNR 5651215. 
administrative action, ${ }^{256}$ and Congress has passed new laws. ${ }^{257}$ These efforts have had varying success, with the holder in due course ${ }^{258}$ doctrine frequently standing in the way of remedies for predatory lending's victims. This is because the holder in due course doctrine protects the ultimate funders of predatory practices, secondary market investors who purchase mortgage notes. ${ }^{259}$ The holder in due course doctrine immunizes them, as good faith purchasers, from liability for any fraud perpetrated by the originator of a loan. ${ }^{260}$ The net result of the application of the doctrine is that a borrower who has been the victim of a fraud not only cannot be compensated for the harm caused by the fraud, but even more, cannot assert the existence of the fraud as a defense against payment on the mortgage note. ${ }^{261}$

Federal law does not provide much by way of protection for homeowners seeking to secure a mortgage. The federal Truth in Lending Act (TILA), originally enacted in 1968, requires certain important disclosures to a borrower by a lender in connection with the origination of a home loan. ${ }^{262}$ TILA, however, has not been successful in stemming the tide of predatory lending practices. ${ }^{263}$ The Home Ownership and Equity Protection Act (HOEPA), an amendment to TILA, enacted in 1994, went beyond disclosure requirements and placed direct limits on certain practices if made in connection with "high cost loans."264 HOEPA's protections are triggered by either a (1) "rate trigger" or an "APR trigger," where the annual percentage rate (APR) of the loan exceeds by $8 \%$ the yield on Treasury securities of comparable maturity ${ }^{265}$ for first lien loans (or above $10 \%$ for subordinate lien loans), or (2) a "fee-trigger," where the total of the loan's points and fees exceeds $8 \%$ of the loan total or $\$ 400$ (adjusted for inflation), whichever is greater. ${ }^{266}$ HOEPA prohibits the inclusion of certain loan terms in high-cost loans that are considered abusive: negative

256. GAO, CONSUMER PROTECTION, supra note 42, at 23-24 (listing major regulatory enforcement actions).

257. See infra pp. 1027-28.

258. The holder in due course doctrine has been codified in section 3-302 of the U.C.C. U.C.C. $\S 3-302$ (2005). Article 3 has been adopted, albeit with some variations, in all fifty states as well as the District of Columbia. Gregory E. Maggs, Determining the Rights and Liabilities of the Remitter of a Negotiable Instrument, 36 B.C. L. REV. 619, 626 (1995).

259. Eggert, Predatory Lending, supra note 32, at 571 (describing the link between securitization in subprime market and predatory lending).

260. See generally id. at 607-40 (discussing impact of holder in due course doctrine on the subprime market).

261. See id. at 612-14.

262. 15 U.S.C. $\S 1638(2000)$.

263. Christopher L. Peterson, Truth, Understanding, and High-Cost Consumer Credit: The Historical Context of the Truth in Lending Act, 55 FLA. L. REv. 807, 898 (2003).

264. 15 U.S.C. \$1639.

265. That is, if a loan had a fifteen-year term, the relevant comparable Treasury would be one with a fifteen-year term as well.

266. 15 U.S.C. $\$ 1602(\mathrm{aa})(1)$, (3); 12 C.F.R. $\S 226.32(\mathrm{a})(1)(\mathrm{ii})(2006)$. 
amortization; ${ }^{267}$ balloon payments where a loan has a term of less than five years; ${ }^{268}$ increases in the interest rate in the event of a default; ${ }^{269}$ and, in certain cases, prepayment penalties. ${ }^{270}$ Moreover, a lender originating a HOEPA loan cannot engage in a pattern and practice of asset-based lending, that is, lending without regard to a borrower's ability to pay. ${ }^{271}$ The Federal Reserve Board's Regulation $\mathrm{Z}$, which implements HOEPA, also places limits on loan flipping: lenders and their affiliates cannot refinance a HOEPA loan within a year unless the refinance is "in the borrower's interest." 272

HOEPA has not materially reduced predatory lending because of two major shortcomings. First, it does not apply to purchase money mortgages (those used to purchase homes) or open-end lines of credit (such as home equity lines of credit). ${ }^{273}$ Second, it only covers a small portion of the mortgage market because its triggers are set very high. ${ }^{274}$ Thus, many states have enacted predatory lending laws to

267. 15 U.S.C. $\S 1639(f) ; 12$ C.F.R. $\S 226.32(d)(2)$. "Negative amortization" refers to loans for which the principal amount of the loan increases (rather than decreases, as with the typical loan) over the term of the loan. See JOINT HUD-TREASURY REPORT, supra note 57 , at 91 .

268. 15 U.S.C. $\S 1639$ (e); 12 C.F.R. $\S 226.32$ (c)(3), (d)(1). For loan terms that exceed five years, balloon payments are permissible, but must be disclosed. 12 C.F.R. $\$ 226.32$ (c)(3).

269. 15 U.S.C. \$ 1639(d); 12 C.F.R. \$ $226.32(d)(4)$.

270. 15 U.S.C. $\$ 1639$ (c)(1)(A); 12 C.F.R. $\$ 226.32(d)(6)$.

271. 15 U.S.C. $\$ 1639(\mathrm{~h})$. HOEPA defines this conduct as extending credit "based on the consumers' collateral without regard to the consumers' repayment ability, including the consumers' current and expected income, current obligations, and employment." Id.

272. 12 C.F.R. $\$ 226.34(\mathrm{a})(3)$. In considering whether a refinancing is in the borrower's interest, Regulation $\mathrm{Z}$ instructs lenders to consider the totality of the borrower's circumstances at the time the credit was extended. Id.

273. Open-end credit is a credit extension where the exact amount of money lent or advanced at any given time is not fixed. 15 U.S.C. $\$ 1602(i)$. It is, in short, a line of credit. Open-end lines of credit are replacing traditional home equity loans in part to avoid HOEPA regulation. ElizaBeth RenUaRT \& KathleEN E. KeEsT, TRUTH IN LENDing § 5.18.1 (4th ed. 1999).

274. GAO, CONSUMER PROTECTION, supra note 42, at 7 ("It appears that HOEPA covers only a limited portion of all subprime loans."). Notwithstanding HOEPA's abrogation of the holder in due course doctrine, Moody's has rated transactions that contain loans that trigger HOEPA. See, e.g., Press Release, Moody's Investors Service, Moody's Expands Consideration of Assignee Liability Residential Mortgages in Securitizations (Jan. 30, 2003) (indicating that Moody's has rated pools containing HOEPA loans). Standard \& Poor's, on the other hand, does not rate HOEPA loans. Press Release, Standard \& Poor's, S\&P Comments on High-Cost Residential Mortgage Loans (Aug. 16, 2001), http://www.rebuz.com/ research/0801-real-estate-research/standard-\&-poors.htm. Additional federal statutes provide other grounds for liability for predatory practices. Lenders may be liable for violations of the Real Estate Settlement Procedures Act, 12 U.S.C. $\$ \S ~ 2601-2617$ (2000), by engaging in kickback schemes. 12 U.S.C. $\$ 2607$ (2000). Certain predatory practices that are targeted based on age, race, national origin, gender, or other prohibited characteristics can also result in violations of the Equal Credit Opportunity Act, 15 U.S.C. $\$ \S 1691$ (a)-(f) (2000), or the Fair Housing Act, 42 U.S.C. $\$ \S 3601-3619$ (2000). Finally, "unfair or deceptive acts or practices" by predatory lenders may expose them to liability under the Federal Trade Commission Act, 15 U.S.C. §§ 41-51 (2000). See generally Advisory Letter from David Hammaker, Deputy Comptroller for Compliance, Comptroller of the Currency, Adm'r of Nat'l Banks, to CEOs of All Nat'l Bank Operating Subsidiaries (Feb. 21, 2003). 
compensate for these and other shortcomings in the federal response to predatory lending. ${ }^{275}$

In the last few sessions, Congress has considered a predatory lending bill first introduced by Representative Robert Ney (R-OH) and now cosponsored by Representative Paul Kanjorski (D-PA) that seeks to preempt state predatory lending laws and enact a uniform federal law in their place. ${ }^{276}$ This bill contains consumer protections that are considerably weaker than those found in the leading state laws and is seen as a proindustry initiative. ${ }^{277}$ As I argue in Part VI.A, it is premature to replace these state efforts to address a new, complex, and rapidly evolving problem with an untested uniform federal standard. ${ }^{278}$

\section{B. North Carolina Enacts a Predatory Lending Law That Builds Incrementally on Federal Law}

North Carolina enacted the first state predatory lending law on July 22, 1999, effective July 21, 2000. The North Carolina law is closely modeled on the federal HOEPA. ${ }^{279}$ It also builds upon protections in North Carolina's usury statute ${ }^{280}$ by prohibiting specific types of loan provisions and lending practices for two categories of loans: "consumer home loans"281 ("North Carolina home loans") and "high-cost home loans" ("North Carolina high-cost home loans"). ${ }^{282}$ A

275. See supra note 254.

276. Legislative Update, AM. BANKER, June 9, 2005, at 5; see RESPONSIBLE LENDING ACT, H.R. 1295, 109th Cong. (2005) (The Ney Bill).

277. See Azmy, supra note 5, at 389 (arguing that the Ney Bill "fails to address many predatory lending practices that states regulate, including balloon payments, negative amortization loans, loan flipping, asset based lending, and others. . . Not surprisingly, the lending industry supports preemption efforts in general, and the Ney bill in particular ....").

278. Id. ("Forestalling preemption of these important state laws will assist federal and other state regulators to better understand and address the predatory lending problem.").

279. 15 U.S.C. $\$ 1639(2000)$.

280. See N.C. GEN. STAT. ANN. \$ 24-2 (West, Westlaw through 2005 Reg. Sess.).

281. Id. § 24-10.2(a) (defining "consumer home loans" to include all mortgage loans that are made to natural persons, primarily for personal, family and household purposes, and are loans secured by liens on one- to four-family residences that are or will become the borrower's principal dwelling). Prohibited practices for North Carolina home loans include financing (directly or indirectly) any credit life, disability, or unemployment insurance, or any other life health insurance premium; flipping is also prohibited. Id. $\S \S 24-10.2(b)$-(c).

282. Id. $\$ 24-1.1 \mathrm{E}(\mathrm{a})(4)$ (defining "high cost home loans" to include loans, reverse mortgage loans, for which (1) the principal amount of the loan does not exceed the lesser of the Fannie Mae conforming loan size limit for a single-family dwelling or $\$ 300,000$, (2) made to a natural person, (3) incurred primarily for personal, family or household purposes, (4) secured by either a security interest in a manufactured home or a mortgage or deed of trust on real property upon which is located a structure designed principally for occupancy by one to four families, either of which is or will be occupied by the borrower as his or her principal dwelling, and (5) meeting one or more of the "thresholds" included in the act). The statute prohibits the following provisions in North Carolina high-cost home loans: call provisions, balloon payments, negative amortizations, increased interest rates, advance payments, and modification or deferral fees. Id. $\S 24-1.1 \mathrm{E}(\mathrm{b})$. Certain lending practices are 
recent empirical study has found that the NC Law operates as designed: predatory loan terms were reduced without materially reducing the supply of subprime credit to low-income borrowers. ${ }^{283}$

A review of the North Carolina law reveals that it (1) clearly delineates between these two categories of loans, (2) does not provide for assignee liability, ${ }^{284}$ and (3) limits damages such that they are a quantifiable liability. ${ }^{285}$ These three aspects of the North Carolina law are of primary concern for the privileged raters as they rate RMBS transactions containing North Carolina loans.

\section{The Privileged Raters Initially Underestimate the Impact of State Predatory Lending Legislation}

As discussed above, when rating mortgage pools, privileged raters typically undertake four distinct analyses: qualitative, quantitative, underwriter and servicer characteristics, and legal risks. ${ }^{286}$ The privileged raters have significantly adjusted their legal risks analysis of RMBS transactions to account for the new predatory lending laws.

On April 28, 2000, Moody's became the first privileged rater to publicly address the phenomenon of predatory lending, nine months after North Carolina passed its law and three months before that law

also prohibited for such loans, including lending without regard to ability to repay, financing points and fees, charging refinancing fees with the same lender, and the direct payment of home improvement contractors. Id. $\$ 24-1.1 \mathrm{E}(\mathrm{c})$. Additionally, all North Carolina high-cost home loan borrowers must receive home ownership counseling. Id.

283. Roberto G. Quercia et al., The Impact of North Carolina's Anti-Predatory Lending Law: A Descriptive Assessment (2003), available at http://www.planning.unc.edu/pdf/ CC_NC_Anti_Predatory_Law_Impact.pdf. An earlier study had concluded that the North Carolina law reduced the supply of credit to low-income borrowers, but the Quercia Study appears to have been better designed and to have relied on superior data. See Azmy, supra note 5, at 380-81 (criticizing study by Gregory Elliehausen \& Michael E. Staten, Regulation of Subprime Mortgage Products: An Analysis of North Carolina's Predatory Lending Law, 29 REAL EST. FIN. \& ECO. 411 (2004)). A report by the Center for Responsible Lending that was released as this Article went to press supports the findings of the Quercia study. LI \& ERNST, supra note 24, at 12-13, 17. It found that North Carolina subprime loans with abusive terms fell over $32 \%$ since the North Carolina law was enacted, while interest rates remained flat. $I d$. at 12 .

284. But see Press Release, Standard \& Poor's, Standard \& Poor's Addresses North Carolina Anti-Predatory Lending Law (Feb. 12, 2004), http://www.mbaa.org/state_update/ states.asp (arguing that, under North Carolina case law, mortgage holders may have assignee liability); see also Overton v. Tarkington, 249 N.C. 340, 344 (1959) (holding that defendant had right to assert usurious interest payments as affirmative defense against assignee of mortgage).

285. See N.C. GEN. STAT. ANN. \$ 24-2 (West, Westlaw through 2005 Reg. Sess.) (usury statute permits damages of "twice the amount of interest paid in an action in the nature of action for debt"); id. \$ 75-1.1 (unfair and deceptive practices act authorizes treble damages and attorney's fees); id. \$24-10.2(e) ("Any person seeking damages or penalties under the provisions of this section may recover damages under either this Chapter or Chapter 75, but not both."). Since the damages are not applied cumulatively and are statutorily defined, they are a quantifiable liability.

286. See supra Part IV.A. 
was to take effect. Moody's initially concluded that allegations of predatory lending practices by mortgage originators would not affect most subprime securitizations, regardless of litigation outcomes, since the transactions are monoline-insured, ${ }^{287}$ meaning that the company that has insured a pool of given mortgages would bear the risk of adverse litigation outcomes. ${ }^{288}$ Moody's also suggested that a senior-subordinated securitization structure ${ }^{289}$ would limit potential liability to issuers who (1) engage regularly in predatory lending practices, (2) are subject to well-publicized allegations, ${ }^{290}$ and (3) have geographically concentrated loan pools. ${ }^{291}$ Based on this analysis, Moody's concluded, "The economic consequences of predatory lending accusations for securitization investors will be limited." 292 This conclusion was based in part upon assumptions as to the limited remedies available to borrowers, should a court find that a lender's practices were predatory. ${ }^{293}$ Indeed, Moody's predicted that a borrower's remedies would be limited to rescission of the loan contract and/or

287. A monoline insurer is an

insurance company that is restricted, by the terms of its charter, to writing insurance policies related to a single type of risk. In a financial context, the monoline insurer unconditionally guarantees the repayment of certain securities issued in connection with specified types of transactions, usually a securitization ... in return for the payment of a fee or premium.

Standard \& Poor's, Structured Finance: Glossary of Securitization Terms (2003), http:// www.securitization.net/pdf/sp_gloss_060103.pdf.

288. KEITH WOFFORD \& DAVID BURKHALTER, MOODY'S INVESTORS SERVICE, PREDATORY LENDING AND HOME EQUITY SECURITIZATIONS 2 (2000), available at http://moodys.com ("First, a large number of deals are fully insured by a monoline bond insurer. In these transactions, the risk of a litigation outcome that impairs the loans in a securitization rests solely with the insurer, not with the security holders. Insured deals constitute $53.25 \%$ of the subprime mortgage-backed securities issued during the period from 1997 through the end of 1999.").

289. Id. (" $[\mathrm{A}]$ mong the approximately $46.75 \%$ of securities issued in transactions that used the senior-subordinate manner of credit enhancement, there is protection in the subordination levels to withstand some unexpected litigation. At the Aaa level, in particular, there is a cushion to protect investors from unforeseen difficulties like lawsuits. Only widespread and concerted litigation against an issuer and its practices, that focuses on a large proportion of that originator's production, would be broad enough to imperil the rating of a Aaa-rated class of securities." (emphasis omitted)). Senior-subordinated securities as a pass-through mortgage issue with two classes, with the subordinated class absorbing the payment risks for both classes. LORE \& COWAN, supra note 8, at 742, app. A.

290. WOFFORD \& BURKHALTER, supra note 288 , at 2 . ("[T] ing the past practices of challenged lenders is likely to lead banking regulators and attorneys general to focus on modifying lenders' future conduct to comply with applicable laws, rather than pursuing claims relating to past acts.").

291. Id. (" $[\mathrm{P}]$ otential plaintiffs in any given loan pool are often geographically dispersed, which makes coordinated, widespread litigation difficult. Originators benefit from this difficulty, because many borrowers will not risk losing their homes without the safety of a large and organized effort to challenge a lender.").

292. Id.

293. Id. at 3 . 
recoupment of any damages from the loan amount owed. ${ }^{294}$ These remedies in individual actions would not pose a significant concern to investors. ${ }^{295}$ Given the limited remedies, sufficient bond insurance, and appropriate structuring of a securitization, Moody's predicted that the effect of antipredatory lending laws on RMBS transactions would be minimal. It appears that Moody's underestimated the extent to which other states would follow North Carolina's lead and enact their own predatory lending laws, because it dramatically changed its analysis in eighteen months. ${ }^{296}$

Nearly two years later, Fitch became the next privileged rater to address the impact of predatory lending on the RMBS market. ${ }^{297}$ Fitch reviewed the assignee liability sections of newly enacted predatory lending statutes and identified the legal risks posed by certain ambiguous provisions in antipredatory lending laws. ${ }^{298}$ Fitch found that such ambiguity "may negatively impact mortgage markets and their participants." ${ }^{299}$ Despite these risks, Fitch concluded, in large part based on discussion with originators, that there were no inherent increased risks to the RMBS market posed by the newly enacted predatory lending laws. ${ }^{300}$

Moody's and Fitch were soon to change their relatively sanguine legal analysis of predatory lending legislation. Moody's came to put more weight on the statutes' punitive damages provisions..$^{301}$ Fitch appeared to reduce its reliance upon statements by subprime lenders as to their own practices and align itself with the more critical voices of the privileged raters. ${ }^{302}$ And Standard \& Poor's, while last to address state predatory lending laws, was the first to come out highly critical of their impact on RMBS investors. ${ }^{303}$

294. Id. ("Set-off or recoupment is the reduction of the loan amount owed by the borrower by the amount of any claims for damages of the borrower against the lender. The borrower would simply reduce the amount owed on his loan by the amount of any damage claims relating to unlawful (predatory) acts. The resulting reduction in the loan amounts would be a loss to the subordinate securities.").

295. Id.

296. See generally Azmy, supra note 5, at 361-78 (2005) (describing more than two dozen state and local predatory lending laws enacted since the North Carolina law was enacted).

297. Press Release, Fitch Ratings, Fitch Ratings Comments on Recent Predatory Lending Legislation (Dec. 24, 2002), http://www.fitchratings.com/corporate/sectors/ rmbs_predatory_lending.cfm?sector_flag $=3 \&$ marketsector $=2 \&$ detail $=\&$ body_content=pred_lend.

298. Id. (referring to the "reasonable tangible net benefit" test contained in HOSA).

299. Id. Fitch's opinion was based on "discussions with the majority of the subprime mortgage loan originators who have confirmed that they do not originate or purchase high cost loans." Id.

300. Id. ("Fitch will continue its discussions with various market participants, including originators, sellers and servicers, to confirm its current belief that risks to transactions have not increased.").

301. Compare text accompanying note 287 supra, with text accompanying note 320 infra.

302. Compare text accompanying notes 291-94 supra, with text accompanying notes 327 35 infra.

303. See infra Part V.D.2. 


\section{The Georgia Experience: Pushing Forward, Pulled Back}

Georgia attempted to take a more aggressive tack than the one taken by North Carolina. It is highly unlikely that they were aware of how the privileged raters would respond. The privileged raters effectively shut down the Georgia mortgage market because they found the Georgia legislation to be too much of a risk to the secondary market because it threatened the standard application of the holder in due course doctrine to RMBS transactions, thereby exposing investors to new forms of potential liability. Not until Georgia amended its law to meet the privileged raters' concerns did the Georgia market reopen.

\section{The Georgia Fair Lending Act Provides for Assignee Liability and Unquantifiable Damages}

The Georgia Fair Lending Act (the "Georgia law") became effective on October 1, 2002. ${ }^{304}$ Below is a brief description of its provisions. Of particular relevance are the provisions for assignee liability $y^{305}$ and for punitive damages. ${ }^{306}$

The Georgia law created three categories of loans: "home loans" ("Georgia home loans"), "covered home loans" ("Georgia covered home loans"), and "high-cost home loans" ("Georgia high-cost home loans"). ${ }^{307}$ Georgia home loans, the broadest category, covered all loans secured by mortgage, security deed, or secured debt within the Fannie Mae conforming loan size. ${ }^{308}$ Georgia covered home loans included all (1) first lien loans with interest rates that are greater than four percentage points above the prime rate or two percentage points above the comparable Fannie Mae or Freddie Mac; (2) junior liens five and a half percentage points above the prime rate or three percentage points above the comparable Fannie Mae or Freddie Mac rates, loans in which the total points and fees, excluding bona fide discount points, ${ }^{309}$ exceed three percentage points; and (3) all Georgia high-cost home

304. GA. CODE ANN. § 7-6A-1 to -13 (West, Westlaw through 2005 Spec. Sess.).

305. Id. § 7-6A-6(a) ("Notwithstanding any other provision of law, where a home loan was made, arranged, or assigned by a person selling home improvements to the dwelling of a borrower, the borrower may assert ... . all affirmative claims and any defenses that the borrower may have against the seller or home improvement contractor ....").

306. Id. § 7-6A-7(a)(3) ("Any creditor found by a preponderance of the evidence to have violated this chapter shall be liable to the borrower for . . . [p]unitive damages . . . .").

307. Id. $\S \S 7-6 \mathrm{~A}-2(7)-(8)$.

308. Id. § 7-6A-2(8).

309. Id. § 7-6A-2(4) (" 'Bona fide discount points' means loan discount points knowingly paid by the borrower for the express purpose of reducing, and which in fact do result in a bona fide reduction of, the interest rate applicable to the home loan; provided, however, that the undiscounted interest rate for the home loan does not exceed by more than one percentage point the required net yield for a 90 day standard mandatory delivery commitment for a home loan with a reasonably comparable term from either the Federal National Mortgage Association or the Federal Home Loan Mortgage Corporation, whichever is greater."). 
loans. ${ }^{310}$ Georgia high-cost home loans were those loans that exceed either an annual percentage rate tied to the HOEPA interest rate trigger ${ }^{311}$ or a fees trigger that is typically five points. ${ }^{312}$

The Georgia law prohibited fifteen specific practices for Georgia high-cost home loans ${ }^{313}$ and four prohibited lending practices for all Georgia home loans, including a ban on loan flipping. ${ }^{314}$ Loan flipping had been the most contested of these prohibitions, since it required that all Georgia covered loans that were refinanced from an existing Georgia home loan provide a "reasonable tangible net benefit" to the borrower. ${ }^{315}$

The Georgia law granted remedies that may be asserted against assignees for violations of the statute; in particular, it granted a borrower the right to assert all affirmative claims and defenses against assignee purchasers of Georgia high-cost home loans. ${ }^{316}$ For Georgia covered home loans, it offered a more limited right: borrowers could assert claims against assignees to offset the outstanding debt. ${ }^{317}$ The damages included actual damages, treble damages, punitive damages, and reasonable costs and attorneys' fees, each of which could be applied cumulatively or individually. ${ }^{318}$ The Georgia law's assignee liability and damages provisions caused the privileged raters to rethink their positions on predatory lending legislation.

\section{The Privileged Raters Exclude Georgia Loans from Their Rated Transactions Because of Concerns That Investors Will Be Liable for Uncapped Damages}

Just a few months after the Georgia law became effective, the privileged raters concluded that Georgia's assignee liability provi-

310. Id. § 7-6A-2(7).

311. 15 U.S.C. $\S 1602(\mathrm{aa})(1)(2000)$.

312. GA. CoDE ANN. § 7-6A-2(18)(B) (West, Westlaw through 2005 Spec. Sess.). The fee trigger is different for loans that are for the principal amount of less than $\$ 20,000$; in that case, the fee trigger is the lesser of $8 \%$ or $\$ 1,000$. Id.

313. Id. $\S 7-6 \mathrm{~A}-5$. The fifteen prohibited practices are prepayment penalties greater than $2 \%$ of the outstanding balance, balloon payments, negative amortization, default interest rates, advance payments, limitations on access to legal remedies, lending without counseling, lending without regard to borrower's ability to repay, direct payment to home improvement contractors, loan modification fees, foreclosure without certified notification fourteen days prior to initiating proceedings, limits on the right to cure default prior to an acceleration clause, foreclosure without notice of the right to cure default, acceleration clauses at the lender's sole discretion, and finally, making loans without disclosure of the assignee liability of the Georgia law. Id.

314. Id. $\S 7-6 \mathrm{~A}-4$. The four prohibited practices are the selling of single premium credit insurance, encouraging default, imposing late penalties greater than $5 \%$, and charging more than $\$ 10$ for transmitting information on the balance due. Id. $\S 7-6 \mathrm{~A}-3$.

315. Id. $\$ 7-6 \mathrm{~A}-4$ (a).

316. Id. § 7-6A-6(b).

317. Id.

318. Id. § 7-6A-6(c). 
sions created potentially unlimited damages for purchasers of Georgia high-cost home loans, and thus pools containing them were too risky to be rated. ${ }^{319}$ The privileged raters' announcements caused turmoil among Georgia lenders who depended heavily on their ability to sell loans on the secondary market; a number of these lenders indicated that they were on the verge of abandoning residential lending in Georgia. ${ }^{320}$ Standard \& Poor's first addressed the Georgia law on January 16,2003 , stating that it would not rate transactions that contained GA home loans. ${ }^{321}$

Moody's staked out a similar position on January 30, 2003, stating that the inclusion of GA home loans in securitization transactions was too risky. ${ }^{322}$ Moody's position marked a change of course from its original position that predatory lending laws would not severely impact the secondary market. ${ }^{323}$ Fitch also retreated from its original position on predatory lending legislation on February 4, 2003, stating that it would not rate transactions with uncapped assignee liability, disallowing the Georgia law loans from its rated transactions. ${ }^{324}$ By refusing to rate transactions containing Georgia home loans and thereby blocking access to the secondary market, the privileged raters forced the Georgia legislature to reevaluate and amend the Georgia law.

While Standard \& Poor's was concerned to some extent with ambiguities in the Georgia law, its main concern was the assignee liability that could attach to the secondary market parties to a securitized transaction containing Georgia home loans. ${ }^{325}$ Moody's echoed Standard \& Poor's position, stating that since there was no cap on punitive damage awards, ${ }^{326}$ the potential unlimited liability that might

319. Press Release, Fitch Ratings, Fitch Ratings Declines to Rate Georgia Loans in RMBS Pools \& Considers Impact to Other Predatory Lending Legislation (Feb. 4, 2003), available at http://www.fitchratings.com; Press Release, Moody's Investors Service, supra note 274; Press Release, Standard \& Poor's, Standard \& Poor's to Disallow Georgia Fair Lending Act Loans (Jan. 16, 2003), http://www.mortgagebankers.org/industry/news/030116b.html.

320. See Ga. BANKER'S Ass'N, GEORGIA FAIR LENDING ACT: THE UNINTENDED CONSEQUENCES 2 (2003), http://www.gabankers.com/issuespredatorylendingwhitepaper.pdf.

321. Press Release, Standard \& Poor's, supra note 319.

322. Press Release, Moody's Investors Service, supra note 274.

323. See supra text accompanying note 288 .

324. Press Release, Fitch Ratings, supra note 319 ("Fitch has concluded that it will not rate transactions with uncapped assignee liability as detailed in the current Georgia Fair Lending Act (GFLA), as it stands today.").

325. Press Release, Standard \& Poor's, supra note 319 ("[T]ransaction parties in securitizations, including depositors, issuers and servicers, might all be subject to penalties for violations under the GFLA."); see also Milligan, supra note 254, at 30 ("Susan Barnes, a managing director in S\&P's residential mortgage group, said the agency was concerned that originators wouldn't be able to adequately determine the threshold between normal home, covered and high-cost loans because of some fuzziness in the language of the law. But the law's unlimited assignee liability was S\&P's 'foremost concern,' says Barnes.").

326. Press Release, Moody's Investors Service, supra note 274 ("The risks are theoretically immeasurable because there is no cap on punitive damage awards. Further, the statute extends liability to loan assignees, which would include securitization trusts."). 
attach to assignees under the Georgia law prevented the inclusion of such loans in rated transactions ${ }^{327}$ Moody's also reversed its position that securitizations could be structured to limit the litigation risks. ${ }^{328}$

Moody's gave direction to the legislature, stating that any Moody's analysis of an amended Georgia law would focus on the risk of assignee liability. ${ }^{329}$ Moody's was particularly concerned with the risks associated with the accidental misclassification of loans (that is, misclassifying a high-risk Georgia high-cost home loan as a low-risk Georgia home loan), ${ }^{330}$ the difficulty of lender compliance with the restrictions on loans in each category, ${ }^{331}$ and above all else, the unlimited liability of the assignee. ${ }^{332}$

Fitch stated that it would not rate transactions with uncapped assignee liability. ${ }^{333}$ Fitch based its position on surveys of RMBS issuers and on an analysis of twenty settled predatory lending cases. ${ }^{334}$ Fitch's method was to examine the frequency and severity of loss for each loan that is subject to a predatory lending statute, such as the Georgia law, to identify the risk that it poses to the RMBS transaction. ${ }^{335}$ Analysis of the twenty settled cases showed an average award of $\$ 76$ million per case, although they were primarily class action suits. $^{336}$ Of particular interest to Fitch was a recent action for $\$ 100,000$ in compensatory damages for which the court awarded $\$ 6$ million in punitive damages. ${ }^{337}$

Fitch recommended that rated securitization trusts remove any exposure to loans that were subject to assignee liability provisions in predatory lending statutes, since compliance procedures alone are not enough to eliminate the risk of loss. ${ }^{338}$ The existence of an as-

327. Id. (" $[T]$ he potential unlimited trust liability makes the risk posed by those Georgia loans inconsistent with Moody's standards for rated securities."). Like Standard \& Poor's, Moody's stated it would continue to rate nonconforming Georgia loans. Id.

328. Id.

329. Id.

330. Id. ("Because some of the criteria for categorizing loans into these tiers may be difficult to measure (e.g., determining indirect compensation to a broker from any source), satisfactory compliance procedures for properly categorizing each loan would prove burdensome and would unlikely be foolproof.").

331. Id. ("[T] he restrictions on 'covered' loans include qualitative elements (i.e., providing a tangible net benefit to the borrower) that raise burdensome compliance issues. Furthermore, the even more onerous additional restrictions on 'high-cost' loans likely present an insurmountable burden to including such loans in a rated securitization.").

332. Id.

333. Press Release, Fitch Ratings, supra note 319.

334. Id.

335. Id. ("The current legal issue concerning predatory lending presents unique challenges to adequately assess the frequency and severity, and ultimately the risk, to a securitization. For example, certain legislation provides an assignee liability clause that adds all parties associated with the trust to the list of potential defendants in a litigation case.").

336. Id.

337. Id.

338. Id. 
signee liability clause represents a meaningful risk to the transaction. And so Fitch stated it would not rate any transaction where assignee liability is combined with unlimited liability, such as is the case with the Georgia law. ${ }^{339}$ To rate a transaction, Fitch requires that it be able to quantify the potential losses. ${ }^{340}$ Antipredatory laws with assignee liability clauses but capped liability allow Fitch to quantify such losses. ${ }^{341}$ Fitch refused to rate all Georgia loans subject to the Georgia law as long as there was a potential for uncapped assignee liability. ${ }^{342}$

The privileged raters all refused to rate RMBS pools containing Georgia loans. This response by the privileged raters evoked harsh criticisms from consumer advocacy groups, the mainstream media, and some academics. ${ }^{343}$ Nonetheless, a number of lenders indicated that they were preparing to pull out of the Georgia residential lending market within days of the privileged raters' announcements. ${ }^{344}$ And the Georgia legislature found that it had to act to meet the privileged raters' concerns as mortgage originators in Georgia stated that they would not be able to make any more mortgage loans. ${ }^{345}$

Georgia had to act notwithstanding the fact that the GSEs disagreed with the privileged raters' assessment of the risks that investors faced from the Georgia law. ${ }^{346}$ The GSEs' assessment appears to have been borne out by (1) the fact that no investor has suffered the effects that the privileged raters had predicted would result from the purchase of loans that were subject to the Georgia law $w^{347}$ and (2) the legal analysis of scholars that study predatory lending laws does not

339. Id.

340. Id.

341. Id.

342. Id.

343. See infra note 350 .

344. Milligan, supra note 254, at 30 (" 'Of course, cutting off Georgia mortgage originators from the secondary market could have led to a catastrophic situation. It was going to cause a collapse of the mortgage market in Georgia, and it came very close to happening before the law was amended,' says [mortgage broker industry representative] Rose. 'We had over $\mathbf{4 0}$ lenders send us letters saying they would no longer do business in the state of Georgia, except for jumbo loans.' ").

345. Id. ("Adds Allen KenKnight, president of the Mortgage Bankers Association of Georgia, Macon, Georgia, and vice president in charge of production at Dunwoody, Georgia-based Prestige Mortgage Co., 'We were within days of not being able to write mortgage loans.' ").

346. See, e.g., Kelly K. Spors, Subprime Bill Aims to Mute State Laws, Wall ST. J., Feb. 14, 2003, at A4 (noting that Fannie Mae and Freddie Mac continued to buy some loans made in Georgia); Fannie Mae, Announcement 03-02, supra note 176; Letter from Michael May to All Freddie Mac Sellers and Servicers, supra note 176 (stating that Freddie Mac would continue to buy all loans made in New Jersey other than New Jersey high-cost home loans).

347. This evidence is far from compelling on its own because there are only a small number of loans that are subject to the unamended Georgia law. 
bear out the Chicken Little interpretation of the privileged raters, but rather is in line with that of the GSEs. ${ }^{348}$

\section{As Its Mortgage Market Dries Up, Georgia Acquiesces to the Demands of the Privileged Raters}

Notwithstanding the weak analysis of the privileged raters, the Georgia legislature quickly responded to the privileged raters by introducing an amendment to the Georgia law, which was enacted on March 7, 2003. ${ }^{349}$ In the months prior to the enactment of the amendment, there were fruitless negotiations between consumer advocacy groups and privileged raters as well as continuing disagreement among legislators regarding how to respond to the privileged raters' concerns. ${ }^{350}$ Notwithstanding this debate, the Georgia legislature amended the Georgia law on March 7, 2003 (the "amended Georgia law"). In order to address the concerns of the privileged raters, the amended Georgia law specified "when and against whom" claims may be asserted, limited the liability that attached, and removed the "covered-loan" category. ${ }^{351}$ The amended Georgia law provides a safe harbor to its assignee liability provision, allowing assignees to avert liability by a showing of "reasonable due diligence" to prevent the acquisition of Georgia high-cost home loans. ${ }^{352}$ Assignee liability is capped at the remaining indebtedness of the loan plus reasonable attorneys' fees and may only attach from an individual lawsuit, not a class action..$^{353}$

\section{The Privileged Raters Allow Georgia Loans to Be Securitized Under an Amended Georgia Law}

The amended Georgia law would prove to be more investor friendly, as the privileged raters readmitted Georgia home loans to

348. See Engel \& McCoy, Wall Street, supra note 32, at 738 ("Costly litigation and significant judgments arguably could have an adverse impact on the value of a loan pool. The reality, however, is that the risk that a securitized loan pool will actually suffer losses from predatory lending litigation is quite small. This is because there are practical impediments to bringing predatory lending claims and also because securitization deals are intentionally structured to reduce such risk."); see also Azmy \& Reiss, supra note 49, at 704-11 (questioning the assumption of "harmful effects" of the New Jersey Home Owner Security Act made by the privileged rating agencies through analysis of continued availability of credit within New Jersey after the law became active).

349. Georgia Fair Lending Act, 1 Ga. Laws. 1 (2003).

350. See, e.g., Ernest Holsendolph \& Robert Luke, Mortgage Lenders Push to Rewrite Fair Lending Act, ATLANTA J.-CoNST., Jan. 23, 2003, at A1; Henry Unger \& Rhonda Cook, Predatory Lending Law to Be Tweaked, ATLANTA J.-ConST., Jan. 24, 2003, at F1; Henry Unger \& Robert Luke, Compromise Reached on Ga. Lending Law, ATLANTA J.-ConST., Feb. 1,2003 , at F1.

351. Georgia Fair Lending Act, 1 Ga. Laws 1 (2003)

352. GA. CODE ANN. $\$ 7-6 A-6(b)$ (West, Westlaw through 2005 Spec. Sess.).

353. Id. § 7-6A-6(c). 
their rated transactions within days of the amendment. ${ }^{354}$ Standard \& Poor's responded on March 11, 2003, stating it would rate transactions including Georgia home loans originated after March 7, 2003. ${ }^{355}$ It would selectively allow Georgia high-cost home loans, since the liability was capped, so long as there was some credit support in place. ${ }^{356}$ This credit support could take the form of, for instance, an agreement by a creditworthy institution to repurchase loans that were made in violation of the law, to limit a securitization trust's exposure to liability ${ }^{357}$ Standard \& Poor's also requires a compliance representation, a statement by a third party verifying the Georgia home loan originators' compliance with the statute, as part of its requirement to rate a transaction containing such loans. ${ }^{358}$

Moody's acted two days later, also finding that the risks associated with Georgia home loans were permissible within its rated transactions. ${ }^{359}$ Moody's discussion of the statute identified practices that lenders and securitizers could implement to protect securitization trusts from liability. ${ }^{360}$ Since the amended Georgia law includes disclosure requirements, ${ }^{361}$ reasonableness standards, ${ }^{362}$ and imposes the strictest requirements on "high-cost" home loans only, ${ }^{363}$ the privileged raters found that it gave adequate direction to lenders..$^{364}$ The amended Georgia law also addresses Moody's concerns regarding miscategorization of loans by removing the "covered-loan" category, thus making it easier to identify the risks associated with individual loans. ${ }^{365}$ Even more important to Moody's is the limitation on assignee liability to the remaining indebtedness and reasonable attor-

354. Standard \& Poor's and Moody's both announced that they would rate all pools that do not contain Georgia high-cost home loans. Press Release, Standard \& Poor's, Standard \& Poor's Will Admit Georgia Mortgage Loans into Rated Structured Finance Transactions (Mar. 11, 2003), http://www.bondmarkets.com/regulatory/s_and_p_georgia_amendment.pdf; Press Release, Moody's Investors Service, Moody's to Rate RMBS Backed by Georgia Home Loans (Mar. 13, 2003), available at http://www.moodys.com/. Indeed, Standard and Poor's preapproved the amended Georgia law. Erick Bergquist, Ga. Amended Predator Law After Pre-approval by S\&P, AM. BANKER, Mar. 11, 2003, at 1, 1, available at 2003 WL 4174771. Fitch announced that it would rate all residential mortgage pools, including those that contained Georgia high-cost home loans, if they also included additional credit enhancements. See Press Release, Fitch Ratings, Fitch to Rate RMBS After Amendment to Georgia Predatory Lending Statute, GFLA (Mar. 14, 2003).

355. Press Release, Standard \& Poor's, supra note 354.

356. Id.

357. Id.

358. Id.

359. Press Release, Moody's Investors Service, supra note 354.

360. Id.

361. GA. CodE ANN. § 7-6A-2(12)(B) (West, Westlaw through 2005 Spec. Sess.).

362. Id. § 7-6A-4.

363. See generally Press Release, Moody's Investors Service, supra note 354.

364. Id.

365. Id. 
neys' fees. ${ }^{366}$ Under the amended Georgia law, Moody's permits Georgia home loans in rated transactions so long as the issuer did the following: gave representations and warranties that the loans were originated in compliance with the law; gave a warranty to repurchase any loans that were, in fact, originated in violation of the statute; and created due diligence procedures to satisfy the safe harbor provisions of the law. ${ }^{367}$

Like Standard \& Poor's, Moody's stated that it would selectively rate pools containing Georgia high-cost home loans, so long as such pools had no more than $2 \%$ of the total loans in the pool and so long as such loans were within the clear, objective standards of the statute. For instance, refinanced Georgia high-cost home loans that could run afoul of the law's antiflipping "reasonable tangible net benefit" test would not fall within a clear, objective standard. ${ }^{368}$ While, in theory, Moody's would rate pools with more than $2 \%$ Georgia high-cost home loans, it indicated that the credit support required to rate such pools would be of prohibitive cost. ${ }^{369}$

On March 14, 2003, closely following the path taken by Standard \& Poor's and Moody's, Fitch announced that it would rate pools including Georgia high-cost home loans, subject to additional credit enhancements. ${ }^{370}$ Fitch indicated that the changes to the assignee liability provisions and limitations on damages assessed against assignees prompted its change of position. ${ }^{371}$ Fitch did differ from the analysis of the other privileged raters to some extent: it found that while the addition of the safe harbor provision for "reasonable due diligence" reduces the risk of assignee liability, the safe harbor provision was subjective because it did not define what "reasonable due diligence" was. ${ }^{372}$ Nonetheless, because the law's liability is, in any case, capped at the remaining indebtedness of the loan plus reasonable attorney's fees, Fitch stated it would rate pools with Georgia home loans, subject to appropriate credit enhancements.

366. Id. ("Finally, and perhaps most importantly to MBS investors, the Amended Act limits assignee liability to the remaining indebtedness on the loan and reasonable attorney's fees, and limits class actions against assignees.").

367. Id.

368. Id.

369. Id. ("Solid representations from financially strong issuers would take on increased importance where high cost loans are included. Transactions containing more than two percent of such 'high cost' loans, or which contain any 'high cost' loans where statutory compliance is a matter of judgment, may be subject to additional protections that have a prohibitive cost. Ultimately, the risk to investors will vary depending on the amount of 'high cost' loans in question and the issuer's financial strength."). The cost of including loans originated prior to the enactment of the amended Georgia law but after the enactment of the Georgia law would also likely be prohibitively high since the amendment is not applied retroactively. Id.

370. Press Release, Fitch Ratings, supra note 354.

371. Id.

372. Id. 
While the privileged raters' decisions to rate transactions contain: ing post-amended Georgia law loans resolved Georgia's funding crisis, they also bring to a head questions as to the role that these private actors should have in setting standards for local regulations of property and consumer finance transactions. In particular, to the extent that the privileged raters are advocates for investors and thereby inaccurately evaluate the risk posed by state predatory lending laws, ${ }^{373}$ it is important to ask whether privileged raters should have the power to veto laws enacted by the several states.

\section{E. The Privileged Raters Take a Stance Against Strong Predatory Lending Legislation}

Shortly after admitting Georgia loans into securitization transactions, each of the three privileged raters issued reports detailing rating criteria for transactions containing loans subject to antipredatory lending laws. These reports put state legislatures on notice as to the privileged raters' requirements and effectively set a framework for standardizing predatory lending legislation that followed.

Moody's was first to issue such a comprehensive report on March 26, 2003. Moody's released a special report regarding the impact of predatory lending on RMBS transactions, changing its position from that of its April 2000 report in light of recently enacted antipredatory lending laws "without well-defined compliance procedures" and which "entail unlimited potential liability." 374 Moody's report stated that such problematic statutes cause difficulty in the securitization process because violations of antipredatory lending statutes reduce the amount of available cash to pay investors. ${ }^{375}$ Although it acknowledged that there were measures that lenders could take to reduce their potential liability, Moody's stated it would not rate transactions unless certain additional conditions for securitization were met. ${ }^{376}$ Those conditions included (1) sufficiently clear statutes so that the lender may comply and (2) limited statutory penalties for noncompliance. ${ }^{377}$ Even with such conditions, Moody's indicated that there remains a risk to

373. See supra Part V.D.2.

374. Press Release, Moody's Investors Service, Moody's Reports on Impact of Predatory Lending Laws on RMBS (Mar. 26, 2003).

375. Id.

376. Id.

377. Id. The other conditions included the lender's demonstration of effective compliance procedures, lender representations that loans comply with statutory requirements, lender agreement to repurchase loans that do not comply with statutory requirements, lender indemnification for damages from the statute under certain circumstances, lender's demonstration that it has the "financial resources and commitment to the business" to demonstrate willingness and ability to honor its repurchase and indemnification obligations, and agreement to concentration limits where the penalties are great or the statutes are ambiguous. Id. 
investors, because lenders may, in certain circumstances, choose to default rather than repurchase afflicted loans. ${ }^{378}$

Standard \& Poor's released its report on April 15, 2003, stating that it would subject RMBS pools containing loans from jurisdictions with antipredatory lending laws to a legal evaluation of the statute of each state ${ }^{379}$ Its legal evaluation methodology was quite similar to that of Moody's. It first considered whether a state's antipredatory lending statute provides for assignee liability. ${ }^{380}$ Where predatory lending laws do provide for assignee liability, Standard \& Poor's would look for clearly delineated loan categories, analyzing whether a purchaser (or servicer) can reasonably determine the category of loan. ${ }^{381}$ Standard \& Poor's then would analyze the severity of penalties, including monetary damages, though even capped categorical damages may pose unlimited liability under the cumulative effect of some laws, such as those that allow for class actions suits. ${ }^{382}$ Standard \& Poor's would not rate transactions containing loans that fall into statutory categories that allow for assignee liability combined with uncapped damages. ${ }^{383}$ Standard \& Poor's would, however, rate loans with capped liability, though the cost of required credit enhancements for some capped liability categories of loans could be prohibitive of securitization. . $^{384}$

Fitch responded with its own document on May 1, 2003, which announced changes to its rating methodology. ${ }^{385}$ Fitch maintains the position, like the other privileged raters, that it would not rate pools containing loans subject to unlimited assignee liability. ${ }^{386}$ Fitch also

378. Id.

379. Press Release, Standard \& Poor's, Evaluating Predatory Lending Laws: Standard \& Poor's Explains Its Approach (Apr. 15, 2003), available at http://www.mortgagebankers.org/ srchindex.html.

380. Id. Loans subject to predatory lending laws that do not provide for assignee liability will not raise rating difficulties for Standard \& Poor's. Id.

381. Id.

382. Id.

383. Id.

384. Id. A statute's clarity in its provisions for violations and safe harbor practices may mitigate the required credit enhancements. Id. Standard \& Poor's also stated that ratings of pools subject to predatory lending laws must include a qualitative determination of a seller's compliance procedures and the ability to identify predatory loans and loans subject to assignee liability. Id. Standard \& Poor's also requires a determination of the seller's creditworthiness, to establish "if a seller is willing and financially able to repurchase any predatory loan for a purchase price that would make a securitization trust whole for any costs incurred in connection with the predatory loan." Id. This rating methodology would determine what credit enhancement was necessary for a particular securitization. Id.

385. Press Release, Fitch Ratings, Fitch Revises Rating Criteria in Wake of Predatory Lending Legislation (May 1, 2003), http://www.fitchratings.com/corporate/events/ press_releases_detail.cfm?pr_id $=85826 \&$ sector_flag= $=3 \&$ marketsector $=2 \&$ detail.

386. Id. 
required warranties of compliance, ${ }^{387}$ and if no high-cost home loans are in the transaction, a representation and warranty of such. ${ }^{388}$ Fitch reserved the right to rate RMBS transactions in jurisdictions where there is assignee liability where that liability is "reasonably limited." 389 Where a breach of those warranties takes place, Fitch requires a repurchase of the affected loan. ${ }^{390}$

Like the other privileged raters, Fitch may require credit enhancements based upon measurements of the severity and frequency of loss for loans covered by predatory lending statutes contained within a securitization trust. ${ }^{391}$ Frequency of loss considers three factors: the number of prohibited acts under the statute, ${ }^{392}$ safe harbor provisions, ${ }^{393}$ and statutory clarity. ${ }^{394}$ Fitch's credit-enhancement analysis will also include a legal and qualitative analysis of the applicable statute by jurisdiction, the type of loans included in the transaction, compliance procedures by the originator or servicer, and the due diligence review by the relevant parties, such as the originator. ${ }^{395}$

These reports represent the most comprehensive statements by privileged raters regarding predatory lending legislation. Each took

387. Id. ("Fitch expects the representation and warranty from the issuer to identify the loans by: (1) type (high cost, covered, etc.), (2) quantity, (3) aggregate dollar amount, and, (4) jurisdiction.").

388. Id.

389. Id.

390. Id. ("In the event of a breach of any such representation or warranty, Fitch will expect a repurchase of the affected loan at the applicable repurchase price. The repurchase price should be equal to: (1) the outstanding indebtedness of the loan (including, but not limited to late fees), plus accrued interest, plus, (2) reasonable attorneys' fees and costs and all other damages which may be incurred by an RMBS transaction under any applicable predatory or abusive lending law. Since the repurchase of the loan will not necessarily insulate an RMBS transaction from assignee or purchaser liability, credit enhancement levels may be adjusted for those RMBS transactions which contain loans originated in jurisdictions with laws that contain such provisions.").

391. Id. Loss severity is calculated by determining the maximum recovery allowed by law under a worst-case scenario. Id.

392. Id. ("LuJoans subject to a high number of prohibitive acts (e.g. high cost' or 'covered' loans) result in an increased likelihood of a violation. These loans are subject to a higher frequency than loans which are subject to a low number of prohibitive act violations (e.g. 'home' loans).").

393. Id. ("Fitch believes that assignee 'safe harbor' clauses may reduce the ability of a borrower to recover from an assignee or purchaser of a loan. Therefore, if the legislation contains safe harbor provisions which limit the exposure of the RMBS transaction to the borrower and if Fitch is comfortable that the safe harbor provisions are available to the RMBS transaction, the additional frequency assigned to a particular loan in that jurisdiction may be significantly reduced.").

394. Id. ("Due to potential errors, such as APRs being calculated incorrectly for loans in certain categories, lenders may unintentionally code a loan as a 'home loan' that is later determined to be a 'high cost' or 'covered' loan-which may ultimately subject the RMBS issuer to assignee liability. In order to protect against this risk, Fitch may assign an added frequency factor to loans originated in jurisdictions with laws that contain assignee or purchaser liability provisions.").

395. Id. 
issue with specific types of provisions: subjective standards, statutory clarity, assignee liability and unlimited liability. It is of note that the privileged raters acted within five weeks of each other and issued mostly parallel guidelines as to the treatment of predatory lending laws that allowed for assignee liability and unquantifiable damages. These parallel moves could be troubling, given that the privileged raters do not face any competition in the grant of regulatory rating licenses. As a result, if the three privileged raters mistakenly interpret the predatory lending laws, there is little hope that market pressures will make them correct themselves.

\section{F. The New Jersey Experience: Testing the Privileged Raters' Resolve}

New Jersey's Home Ownership Security Act (the "New Jersey law" or "HOSA") became effective on November 26, 2003 after the three privileged raters issued their comprehensive guidelines on predatory lending statutes. ${ }^{396}$ New Jersey amended HOSA (the "amended New Jersey law") on July 6, 2004, after the privileged raters decided not to rate pools containing certain types of New Jersey loans. ${ }^{397}$ Like the Georgia law, the New Jersey law prohibited specific lender practices for three categories of loans and it included assignee liability ${ }^{398}$ and punitive damages provisions because they expose investors to unlimited liability. ${ }^{399}$ These two provisions were most problematic for the privileged raters.

The New Jersey original statute attempted to hew its own path on solving the problem of predatory lending, but the privileged raters ultimately forced New Jersey back to the standardized path that they had promulgated in their guidelines when New Jersey amended its law the year after it was first enacted.

\section{The Original New Jersey Law}

The New Jersey law, like the Georgia law, created three categories of loans which were subject to increasing levels of regulation and followed similar thresholds to define its categories. New Jersey "home loans" were the broadest category, applicable to one- to sixfamily principle dwelling secured by a mortgage or deed of trust, or "[a] security interest in a manufactured home." 400 Unlike the compa-

396. N.J. STAT. ANN. $§ 46: 10 B-35$ (West, Westlaw through L.2006, c. 17).

397. Azmy \& Reiss, supra note 49 , at 712-13.

398. N.J. STAT. ANN. § 46:10B-27 (West, Westlaw through L.2006, c. 20) (setting forth assignee liability for certain types of loans).

399. Id. §46:10B-29(b)(1)(b) (allowing for "[p]unitive damages, when the violation was malicious or reckless in appropriate circumstances as determined by the fact-finder").

400. Id. $\S 46: 10 B-24$. The New Jersey law prohibits, as economically unjustifiable, the same practices as the Georgia law for all New Jersey home loans. Those practices include the following: packing single premium credit insurance into fees, encouraging default; late 
rable Georgia law category, "New Jersey covered home loans" were defined by points and fees trigger only; that is, it does not have an APR trigger. New Jersey covered home loans included loans that had points and fees greater than $4 \%$ for loans greater than $\$ 40,000$, and a higher trigger for other loans. ${ }^{401}$ Like the Georgia law, the New Jersey law incorporated HOEPA's APR trigger to define "New Jersey high-cost home loans." The New Jersey law also set a points and fees trigger on a sliding scale, all lower than HOEPA's standards: for total loan amounts of $\$ 40,000$ or greater, $4.5 \%$ or more of the total loan amount and higher proportions for smaller loans. ${ }^{402}$ The New Jersey law also added two new subcategories of home loans: "home improvement loans" and "manufactured housing loans."

Like its Georgia law counterpart, ${ }^{404}$ the "New Jersey covered home loan" category had only one limitation particular to that category of loan: it banned loan flipping where there was no "reasonable tangible net benefit." ${ }^{405}$ The New Jersey high-cost home loan category also incorporated similar prohibitions as the comparable Georgia law category. ${ }^{406}$

The New Jersey law's assignee liability provision allowed New Jersey high-cost home loan borrowers to assert all affirmative claims

payment fees outside set limitations; discretionary loan acceleration; and charging fees for a payoff letter. $I d . \S 46: 10 \mathrm{~B}-25$ (a), (c)-(f). Of course, these prohibitions also apply to all New Jersey covered home loans and New Jersey high-cost home loans, as such loans are types of the New Jersey home loans. Id. § 46:10B-25(e).

"High-cost home loan" means a home loan for which the principal amount of the loan does not exceed $\$ 350,000$, which amount shall be adjusted annually to include the last published increase of the housing component of the national Consumer Price Index, New York-Northeastern New Jersey Region, in which the terms of the loan meet or exceed one or more of the thresholds as defined in this section.

Id. $\S 46.10 \mathrm{~B}-24$.

401. Id. $\S 46: 10 \mathrm{~B}-24$. The points and fees trigger is $4.5 \%$ for loans that have principal amounts of less than $\$ 40,000$ or if insured by the Fair Housing Administration (FHA) or guaranteed by the Department of Veterans Affairs (VA).

402. Id. The thresholds for smaller loans are as follows: for total loan amounts of $\$ 20,000$ to $\$ 39,999,6 \%$ of the total loan amount; and for total loan amounts of $\$ 1$ to $\$ 19,999$, the lesser of $\$ 1,000$ or $6 \%$. Id.

403. Azmy \& Reiss, supra note 49, at 712 n.316 (describing treatment under New Jersey law of home improvement loans and manufactured housing loans). Manufactured homes include the following: modular homes, panelized homes, pre-cut homes, and mobile homes. See $§ 46: 10 \mathrm{~B}-24$.

404. See supra Part V.D.

405. $\S 46: 10 \mathrm{~B}-25(\mathrm{~b})$.

406. $\S 46: 10 \mathrm{~B}-26$. These prohibitions include those on balloon payments, negative amortization, increased default interest rates; $\$ 46: 10 \mathrm{~B}-26$ (c), prepaid finance charges, limitations on access to legal remedies, the making of loans without mandatory notices, $\S 46: 10 \mathrm{~B}$. $26(f)$, the making of loans without mandatory counseling, the direct payment to home im. provement contractors (i.e., the bypassing of the borrower when lender makes payments on home improvement loans), § 46:10B-26(h), loan modification fees, same-creditor refinances of existing New Jersey high-cost home loans, $\S 46: 10 B-26(i)$ and the financing of fees greater than $2 \%$ of the total loan balance. Id. 
and defenses against purchasers and assignees. ${ }^{407}$ The New Jersey law did provide a safe harbor provision for unwary secondary market purchasers who could show that they exercised due diligence in identifying and avoiding the purchase of "high-cost home loans." 408 Like the Georgia law, the New Jersey law limited assignee liability for the "covered home loan" category to the outstanding obligation plus costs and attorneys' fees. ${ }^{409}$ Remedies under the act included statutory damages, punitive damages, reasonable costs and attorneys' fees, and injunctive, declaratory and equitable relief. ${ }^{410}$

\section{The Privileged Raters Quickly Respond}

Although it did not go into effect until November 26, 2003, Governor McGreevey signed the New Jersey law on May 1, 2003.411 The day after the Governor signed HOSA, Standard \& Poor's announced that it would not rate pools that contain certain New Jersey residential loans. ${ }^{412}$ In contrast, Moody's and Fitch quickly concluded that, despite some ambiguities in the Act's damages provisions, the risks to assignees were low enough that they would continue to rate pools containing most types of New Jersey residential loans. ${ }^{413}$ Thus, despite similarities between the original Georgia law and the New Jersey law, Moody's and Fitch reacted differently to New Jersey's law, appearing to prevent a repeat of the funding crisis that occurred in Georgia despite Standard \& Poor's more restrictive position.

Standard \& Poor's reported its position regarding the New Jersey law more than six months before the law would become effective. ${ }^{114}$ Standard \& Poor's stated that it would not allow several categories of New Jersey loans within securitizations that it rated, claiming that several of the Act's damages provisions were unclear and, therefore, might expose assignees to unlimited liability. ${ }^{415}$ Those categories include high-cost home loans, covered home loans, home improvement

407. § 46:10B-27(a).

408. $\$ 46: 10 \mathrm{~B}-29(\mathrm{c})$.

409. $§ 46: 10 \mathrm{~B}-29(\mathrm{~b})$.

410. Id.

411. Azmy \& Reiss, supra note 49 , at 669 .

412. Press Release, Standard \& Poor's, S\&P Report Addresses New Jersey State Predatory Lending Law (May 2, 2003); see Randy Diamond, Mortgage Reform Law in Trouble from Start; Rating Service Raises Worries About Liability, REC. (Bergen County, N.J.), May 3,2003 , at A1 ("S\&P said it was concerned the law would hold issuers, and in some cases buyers, of mortgage-backed securities liable for violations.").

413. Press Release, Fitch Ratings, Fitch Ratings Responds to New Jersey Predatory Lending Legislation (June 5, 2003), http://fitchratings.com/corporate/sectors/ rmbs_predatory_lending.cfm?sector_flag $=3 \&$ marketsector $=2 \&$ detail $=\& b$ body_content=pred_lend.

414. The law went into effect on November 26, 2003 and Standard \& Poor's released their press release on May 2, 2003. See Press Release, Standard \& Poor's, supra note 412.

415. Id. 
loans, and manufactured housing loans. ${ }^{416}$ Standard \& Poor's stated it would allow "home loans," reverse mortgages and loans on nonprimary residences in its rated transactions. ${ }^{417}$

Even though Moody's and Fitch indicated that they would still rate transactions containing New Jersey mortgage loans, Standard \& Poor's position threatened to destabilize the New Jersey mortgage market and motivated the lending industry in New Jersey to lobby for a significant dilution of the New Jersey law's assignee liability provisions. ${ }^{418}$ However, many of Standard \& Poor's concerns were unmerited. For example, Standard \& Poor's asserted, without clear explanation, that the Act creates unlimited liability for assignees of "covered home loans." 419 However, assignee liability for New Jersey covered home loans is specifically limited by the Act (1) to suits brought in an individual capacity and (2) for damages that cannot exceed the borrower's "remaining obligation under the loan plus costs and [reasonable] attorneys' fees." 420

Fitch took a more accepting opinion of the New Jersey law on June 5, 2003, following its revised criteria. ${ }^{421}$ In contrast to Standard \& Poor's position, Fitch stated it would rate covered loans, manufactured home loans, and home improvement loans in its rated transactions, subject to the appropriate credit enhancement. ${ }^{422}$ Fitch believed that the risks posed by New Jersey were less than those posed by Georgia because the New Jersey law allows for mitigating factors. ${ }^{423}$ Predictably, Fitch declined to rate New Jersey high-cost home loans since the combination of unlimited liability and assignee liability present an unquantifiable liability to investors. ${ }^{424}$

While New Jersey high-cost home loans can be part of a rated transaction due to errors in the origination process, Fitch recognized the adequacy of New Jersey's safe harbor provisions which limit the exposure of lenders with reasonable compliance procedures in

416. Id.

417. Id.

418. S\&P Surprises Lenders; Decision Not to Rate Certain Pools Cuts New Predatory Law Support, BroKeR MAG., June-July 2003, at 30, 30 (quoting E. Robert Levy, Executive Director, Mortgage Bankers Association of New Jersey/League of Mortgage Lenders, "We obviously are not going to be able to live with the bill in [the] present form, unless S\&P changes their position.").

419. Press Release, Standard \& Poor's, supra note 412.

420. Azmy \& Reiss, supra note 49, at 702; see N.J. STAT. ANN. $\$ 46: 10 B-27$ (c) (West, Westlaw through L.2006, c. 20).

421. Press Release, Fitch Ratings, supra note 413.

422. Id.

423. Richard Newman, Fitch Won't Rate High-Cost Loans in New Jersey; Predatory Lending Law Causing Concern on Wall Street, REC. (Bergen County, N.J.), June 6, 2003, at B1 (" 'Georgia had unlimited liability that could not be mitigated,' said Fitch's senior director, Michael Nelson.").

424. Press Release, Fitch Ratings, supra note 413. 
place. ${ }^{425}$ Fitch determined that a third-party certification of the loan pool, which includes recalculation of the APRs based on information taken from the loan documents would be sufficient to satisfy Fitch's due diligence requirements. ${ }^{426}$ While Fitch questioned what "reasonable due diligence" would suffice to invoke the New Jersey law's safe harbor provisions, it stated that it would not rate any transactions where sellers could not show evidence that its compliance procedures fall within the safe harbor provisions, as those provisions were interpreted by Fitch. ${ }^{427}$

Unlike Standard \& Poor's and Fitch, Moody's stated on September 22,2003 that it would rate pools containing New Jersey high-cost home loans and covered home loans. ${ }^{428}$ While recognizing that these two categories pose greater risk to investors than ordinary "home loans," Moody's stated that few of those loans would be securitized based on that inherent risk. ${ }^{429}$ New Jersey high-cost home loans bear the risk of damages including the outstanding balance of the loan plus costs, as well as the potential for class action lawsuits. ${ }^{430}$ Refinanced New Jersey high-cost home loans pose even greater risk to the investor based on the requirement that the refinance provide a "reasonable tangible net benefit." ${ }^{331}$ Because of the subjective standard, Moody's stated it would exclude refinanced high-cost home loans from its rated transactions. ${ }^{432}$ Otherwise, Moody's will rate pools that have less than $2 \%$ purchase money (for example, not refinanced) New Jersey high-cost home loans. ${ }^{43}$ Moody's will allow up to $5 \%$ refinanced New Jersey covered home loans even though such loans are subject to the "reasonable tangible net benefit" requirement, because New Jersey covered home loans are not exposed to

425. 'Id.

426. Id.

427. Id. ("The Act is unclear as to what will be considered reasonable due diligence in New Jersey under the limited damages provision of the Act.").

428. Press Release, Moody's Investors Service, Moody's to Continue to Rate RMBS Backed by New Jersey Home Loans (Sept. 22, 2003).

429. Id. (Moody's "believes that two categories of loans defined in the New Jersey Act'high cost home loans' and refinanced 'covered home loans'-represent increased risks to RMBS securitizations. Thus, the agency expects that few of the high cost home loans' and refinanced 'covered home loans' originated in New Jersey will be securitized.").

430. Id.

431. N.J. STAT. ANN. § 46:10B-24 (West, Westlaw through L.2006, c. 20) ("Covered Home Loan") (no longer in the statute).

432. Press Release, Moody's Investors Service, supra note 428 ("Among other things, the New Jersey Act requires 'high cost home loans' that refinance existing loans to provide a 'tangible net benefit' to borrowers. Christine Lachnicht, a Moody's vice president-senior analyst, indicated that because the New Jersey Act does not provide an objective standard for what constitutes a 'tangible net benefit,' it will be more difficult for lenders and issuers to implement and demonstrate effective compliance and due diligence procedures for refinanced 'high cost home loans.' Therefore, Moody's anticipates that the risk of including refinanced high cost loans in RMBS deals will eliminate their inclusion in future deals.").

433. Id. 
unlimited liability and are not subject to class action lawsuits. ${ }^{434}$ Moody's placed no limit on purchase money "covered home loans." 435 Moody's also requires the repurchase of loans that violate its guidelines and indemnification of the securitization trust for any losses incurred because of the inclusion of such a loan. ${ }^{436}$ All other loans may be included in rated transactions as long as the issuer demonstrates strong compliance procedures with the New Jersey law ${ }^{437}$ and due diligence procedures to avail themselves of the safe harbor provision. ${ }^{438}$ While Standard \& Poor's stated that the loan categories were unclear, ${ }^{439}$ subjecting assignees to potential liability, Moody's stated that the New Jersey law provided clear and defined thresholds which permit effective compliance procedures.40 Consumer advocates lauded Moody's position, stating that it correctly balanced the needs of consumers and investors. ${ }^{441}$ And indeed, this seemed to be the case. But just getting Moody's on board would not be enough to satisfy secondary market players; given that RMBS transactions typically need a rating from both Moody's and Standard \& Poor's, ${ }^{442}$ Standard \& Poor's actions were closely watched.

\section{Standard \& Poor's Backs Down}

H. Robert Tillman, head of the New Jersey Department of Banking and Finance, commented on the relative positions of the privileged raters, stating, "All of the major rating agencies do not have to agree on how to treat New Jersey loans. The market can function with Moody's and Fitch." ${ }^{43}$ This proved to be an optimistic assessment.

From the day after the law was signed to the day before it came into effectiveness, Standard \& Poor's maintained its position that the New Jersey law lacked clarity and, as such, New Jersey loans could not be included in their rated transactions. Then, Standard \& Poor's backed down from its original position on the New Jersey law two

434. Id.

435. Id.

436. Id.

437. Id.

438. Id.

439. See supra text accompanying notes 415-416.

440. Press Release, Moody's Investors Service, supra note 374.

441. See, e.g., Richard Newman, Moody's Differs on Predatory Lending Law; Will Rate Pools Including High-Cost Mortgages, REc. (Bergen County, N.J.), Sept. 23, 2003, at L8 (quoting Debbie Goldstein, a consumer advocate, as saying, "Moody's successfully balanced the needs of consumers in protecting their homes from foreclosure and in protecting investors against 'unintended consequences'-such as catastrophic liability for an inadvertent purchase of a loan that's in violation of the law.").

442. See supra note 176.

443. Press Release, Standard \& Poor's, supra note 412. 
days prior to its effective date. ${ }^{444}$ Notwithstanding its denial, it appears that Standard \& Poor's purpose in responding so quickly to the New Jersey law was to push New Jersey to amend the law prior to its effective date while ensuring that it could keep this business if the New Jersey law was not amended.

As it appeared that the New Jersey law would not be amended, Standard \& Poor's released a report on the role of predatory lending laws in RMBS transactions on October 7, 2003. ${ }^{445}$ The report speculated generally on the effect of laws, such as the New Jersey law, on lender's practices, stating that lenders may reduce lending in a particular state to protect themselves, the increased compliance cost may make such loans unprofitable, and that a decreased purchase market may prompt a reduction in originations. ${ }^{446}$ Standard \& Poor's went on to state that predatory lending laws may reduce the funds available to pay investors in RMBS transactions that contain loans from jurisdictions with tough predatory lending laws, which is most relevant to Standard \& Poor's and is determinative of its ratings. ${ }^{447}$ Standard \& Poor's then reiterated its previous issues with assignee liability and uncapped liability. ${ }^{448}$ Standard \& Poor's concluded by stating that while it is in favor of predatory lending laws, its role is to assess risk associated with RMBS transactions and not to make public policy. ${ }^{449}$ This statement is inconsistent with its actions.

While Standard \& Poor's October 7th report did not address the New Jersey law directly, it took a less restrictive position on antipredatory lending laws than that contained in its May 2, 2003 statement on the New Jersey law. ${ }^{450}$ Interestingly, the report serves one of three conceivable purposes. First, it is possible that Standard \& Poor's expected an upcoming amendment to the New Jersey law but needed a basis to amend its previous report in case the law did not change. Second, it may have felt pressured to reaffirm its stance,

444. Press Release, Standard \& Poor's, Standard \& Poor's Permits Additional New Jersey Mortgage Loans into Rated Single Family Transactions (Nov. 25, 2003), available at http://www.mortgagebankers.org/srchindex.html.

445. Press Release, Standard \& Poor's, Anti-Predatory Lending Laws Assume a Prominent Role in the U.S. RMBS Market (Oct. 7, 2003), available at http:// www.mortgagebankers.org/srchindex.html.

446. Id.

447. Id.

448. Id.

449. Id. ('Standard \& Poor's has stated that, as a public policy matter, it is in favor of statutes that attempt to curb predatory lending. Standard \& Poor's also acknowledges, however, that its role is to evaluate the credit risk to investors associated with antipredatory lending legislation and not to recommend public policy. The making of public policy is the responsibility of elected officials."). While facially attractive, there is something incoherent about this position: if Standard \& Poor's cannot consider public policy in its assessments, the fact that it favors something as a matter of public policy is of no practical effect.

450. See Press Release, Standard \& Poor's, supra note 412. 
separate from those of Moody's and Fitch, after Moody's September 22, 2003 report directly contradicted Standard \& Poor's position that the statute was unclear as to the categorization of loans. Last, Standard \& Poor's, having faced scrutiny in the press from consumer advocacy groups, may have needed to assuage the tensions it generated by undercutting the effectiveness of a consumer protection law.

Standard \& Poor's revised its position on November 25, 2003, two days before the New Jersey law would go into effect, stating it would rate the formerly disallowed covered home loans, manufactured housing loans and home improvement loans. ${ }^{451}$ Like Fitch's and Moody's positions, Standard \& Poor's now required compliance representations and demonstrated compliance procedures sufficient to identify New Jersey high-cost home loans, New Jersey covered home loans and whether such loans are in violation of the statute. ${ }^{452}$ Unlike Moody's, Standard \& Poor's still excluded "high-cost home loans." To that extent, Standard and Poor's requires an "Exclusion Representation," that is, representations of effective procedures to exclude New Jersey high-cost home loans so the loans in a pool can fall within the New Jersey law's safe harbor provision. ${ }^{454}$ Finally, the party making compliance and exclusion representations must be financially stable enough to repurchase loans that violate Standard \& Poor's guidelines and indemnify the securitization trust for losses incurred by such violations. ${ }^{455}$

As of the New Jersey law's effective date, the New Jersey experience stands in stark contrast to the lending catastrophe that nearly occurred in Georgia. ${ }^{456}$ Differences in the laws arguably demonstrate an intent by New Jersey legislature to afford investors greater ability to avoid harsh penalties while remaining steadfastly opposed to predatory lending practices. Yet, Standard \& Poor's markedly similar responses to the two laws, as compared to the more nuanced responses of its competitors, raise concerns as to whether it is biased. Standard

451. Press Release, Standard and Poor's, Standard \& Poor's Permits Additional New Jersey Mortgage Loans into Rated Single Family Transactions (Nov. 25, 2003), available at http://www.mortgagebankers.org/srchindex.html.

452. Id.

453. Id. ("Standard \& Poor's will continue to exclude High-Cost Home Loans because of the potential for uncapped statutory and punitive damages.").

454. Office of the Comptroller of the Currency, Statement of the Comptroller of the Currency John D. Hawke, Jr. Regarding the Issuance of Regulations Concerning Preemption and Visitorial Powers 1 (Jan. 7, 2004), available at http://www.occ.treas.gov/ 2004-3aComptrollersstatement.pdf ("[W]e have no evidence that national banks (or their subsidiaries) are engaged in such practices to any discernible degree. Virtually all State Attorneys General have more than once expressed the view that information available to them does not show that banks and their subsidiaries are engaged in abusive or predatory lending practices. On those limited occasions where we have found national banks to be engaged in unacceptable practices, we have taken vigorous enforcement action.").

455. Id.

456. See supra Part V.D. 
\& Poor's initial position highlights its interest in supporting secondary market investors rather than fair and equitable lending practices. Even so, New Jersey would not be able to withstand Standard \& Poor's next change of position which occurred on May 13, 2004. ${ }^{457}$

\section{Standard \& Poor's Reverses Course and Imposes New Restrictions, Forcing New Jersey to Amend Its Law}

On that date, Standard \& Poor's released its new evaluation criteria for rating RMBS transactions. ${ }^{458}$ The new criteria subjected loans in each jurisdiction to a quantitative analysis to account for the clarity of the statutory provision, the potential loss severity, and potential mitigating factors. ${ }^{459}$ "Standard \& Poor's believes that when the risk associated with violating an antipredatory lending law is quantifiable, Standard \& Poor's will allow loans governed by that law in its rated transactions." 460 In jurisdictions with assignee liability and the potential for liability in excess of the original balance of the loan, it took the position that the risk assessment must be increased where the antipredatory lending laws have subjective standards. Standard \& Poor's requires credit enhancements to properly evaluate those risks in specific jurisdictions. ${ }^{461}$

457. Press Release, Standard \& Poor's, Standard \& Poor's Clarifies Credit Risk Posed by Anti-Predatory Lending Laws (May 13, 2004), http://www.mortgagebankers.org/industry/ news/04/0518.html.

458. Id.

459. Press Release, Standard \& Poor's, Standard \& Poor's Implements Credit Enhancement Criteria and Revises Representation and Warranty Criteria for Including AntiPredatory Lending Law Loans in U.S. Rated Structured Finance Transactions (May 13, 2004), http:/www.mortgagebankers.org/industry/news/04/0518.html.

The loss severity on each affected loan will be calculated based on the jurisdiction, taking into account the principal balance of each loan, the interest rate, and the term of the loan. After calculating this loss severity, Standard \& Poor's will determine the number of defensive claims (claims raised by the borrower in a foreclosure action) by using the appropriate foreclosure frequency. It will then determine the frequency of affirmative claims (claims made against the lender prior to default of the loans) by assuming that a percentage of the nondefaulted loans are likely to be subject to affirmative claims. The total credit enhancement for affected loans is then calculated based on the percentage of losses on affirmative and defensive claims. Therefore, the total credit enhancement will depend on the number loans in each pool, foreclosure frequencies, and the jurisdictional distribution of the loans.

Id.

460. Id.

461. Id.

Standard \& Poor's credit enhancement is based on an assessment of potential losses to the securitization transaction. This calculation involves an evaluation of several factors, including the number of successful lawsuits likely to be asserted against the issuer based on the jurisdictions involved, statutory borrower rights, the maximum potential damages that could be awarded, and an assessment of the likely amount of damages to be awarded. 
In deciding that sellers of North Carolina high-cost home loans did not require further credit enhancements, Standard \& Poor's found that the North Carolina law had among the highest loss severity percentages among jurisdictions with quantifiable damages ${ }^{462}$ and subjective standards but also had sufficient mitigating factors which are determinative of the credit enhancement requirement for jurisdictions with assignee liability and quantifiable damages. ${ }^{463}$ In contrast, Standard \& Poor's refused to rate both Georgia and New Jersey high-cost home loans because of the lack of quantifiable damages and sufficient safe harbors, even though they had lower loss severity percentages. ${ }^{464}$ Because Standard \& Poor's required credit enhancements would impose unacceptable costs on the New Jersey mortgage market, the New Jersey legislature was forced to acquiesce and amend its predatory lending law on July $6,2004 .{ }^{465}$

There were three important amendments to HOSA in response to rating agency concerns. ${ }^{466}$ First, the covered home loan category was removed because the privileged raters found the loan flipping test too ambiguous. ${ }^{467}$ Second, the amendment limited plaintiffs from seeking HOSA's remedies in class actions; this change (in addition to reducing potential recoveries for plaintiffs) allowed the privileged raters to more easily quantify potential damages under the law. ${ }^{468}$ Finally, the amendment granted New Jersey's Department of Banking and Insurance the power to promulgate regulations to effectuate the intent and purpose of all of the provisions of HOSA (as opposed to the handful of provisions that the Department had authority over in the original statute), a change that would again reduce ambiguity for the

462. Id. (noting that loans with unquantifiable liability are excluded from Standard \& Poor's ratings).

463. Id. Compare Cleveland Heights, Ohio's statute with a loss severity percentage of $37 \%$ and no mitigating factors that requires credit enhancements with North Carolina's statute with a loss severity of $275 \%$ and mitigating factors that does not require credit enhancements. $I d$. Also, remember that loans with unquantifiable liability are excluded from Standard \& Poor's ratings.

464. Id. Georgia's loss severity percentage was set at 110\%; New Jersey's loss severity percentage was $110 \%$, much lower than North Carolina's $275 \%$. Id.

465. See, e.g., Erick Bergquist, Predatory Laws: S\&P's Awkward Position, AM. BANKER, May 18, 2004, at 1, 1 (finding that Standard \& Poor's credit enhancements for New Jersey loans would be "high enough to scare lenders away"). It is important to note that lenders operating in New Jersey were continuing to lobby the New Jersey legislature to weaken HOSA after it went into effect. See, e.g., Coalition for Fair Lending, Predatory Lending Law Deserves Time to Work (undated) (on file with author).

466. Act of July 6, 2004, Ch. 85, 2004 N.J. Laws 874.

467. Id. As an apparent compromise for eliminating the covered home loan category the amended law broadened the scope of the New Jersey high-cost home loan category to include more loans. Another important, pro-lender change was the exclusion of prepayment penalties from the "points and fees calculation" when a refinancing occurs by the same broker but with a different lender. Id.

468. Id. 
privileged raters. ${ }^{469}$ While these changes were not uniformly bad, they tended to be pro-lender and were adopted largely to satisfy the demands of Standard \& Poor's.

\section{THREe Forces MAY STANDARDIZE THE OPERATIONS OF THE SUBPRIME MARKET}

In addition to privileged rater predatory lending law underwriting guidelines, there are two other forces that may impose greater standardization upon the subprime mortgage market: (1) federal preemption by legislation and/or regulation and (2) GSE buying guidelines. Standardization can take many forms and can vary in scope. Each push to standardize must be independently evaluated to determine whether it is desirable.

\section{A. Federal Preemption Is Premature}

The United States has a dual banking system, one in which both states and the federal government charter and regulate banks and other savings institutions. Within this dual system, the federal government has the power to preempt state lending regulations. Indeed, federal regulators have already preempted the application of state predatory lending laws to a broad array of lending institutions and Congress is considering legislation to preempt their application to the remaining financial institutions that are still regulated by such laws. Professor Azmy has exhaustively reviewed these efforts and they merely require summarizing and updating for my purposes. ${ }^{470}$

\section{Regulatory Preemption}

The Office of Thrift Supervision, which regulates savings and loan and savings banks, has preempted state predatory loans as to those entities and their operating subsidiaries. ${ }^{471}$ The Office of the Comptroller of the Currency has also preempted state predatory lending laws as to national banks and their operating subsidiaries. ${ }^{472}$

469. Id.

470. See generally Azmy, supra note 5, at 382-90; see also Christopher L. Peterson, Federalism and Predatory Lending: Unmasking the Deregulatory Agenda, 78 TEMP. L. REV. 1 (2005); Julia P. Forrester, Still Mortgaging the American Dream: Predatory Lending, Preemption, and Federally-Supported Lenders (ExpressO Preprint Series, Working Paper No. 879, 2005), available at http://aw.bepress.com/expresso/eps/879/.

471. O.T.S. Chief Couns. Op. P.2003-6 (Sept. 2, 2003), http://www.ots.treas.gov/docs/ r.cfm?56306.pdf; O.T.S. Chief Couns. Op. P-2003-5 (July 22, 2003), http://www.ots.treas.gov/ docs/r.cfm?56305.pdf; O.T.S. Chief Couns. Op. P-2003-2 (Jan. 30, 2003), http//www.ots.treas.gov/ docs/r.cfm?56302.pdf; O.T.S. Chief Couns. Op. P-2003-1 (Jan. 21, 2003), http:// www.ots.treas.gov/docs/r.cfm?56301.pdf.

472. 12 C.F.R. pts. 7, 34 (2006). The National Credit Union Administration has also preempted HOSA as to federal credit unions, N.C.U.A. Assoc. Gen. Couns. Op. 03-1106 (Jan. 28, 2004), http://www.ncua.gov/RegulationsOpinionsLaws/opinion_letters/2003_letters/ 
These preemption actions will only have a modest effect on the efficacy of predatory lending laws; it is generally agreed that federally regulated lenders do not engage in much predatory lending. ${ }^{473}$ The only aspect of these preemption rulings that will significantly impact predatory lending is that they also apply to the state-chartered operating subsidiaries of nationally chartered lenders. Major nationally chartered lenders have purchased subprime lenders that have been accused of predatory behaviors ${ }^{474}$ which will not be subject to state predatory lending laws. But there is reason to believe that nationally chartered lenders will not tolerate predatory behaviors in their operating subsidiaries because of reputational concerns ${ }^{475}$ and existing regulation. ${ }^{476}$

It is difficult to answer two important questions that arise from the federal preemption of these laws: How many subprime lenders are impacted and what share of the market do they have? But I preliminarily conclude that this preemption, while unwise in our dual banking system, will only have a moderately negative impact on the effectiveness of state predatory lending laws because few predatory lenders and only a small portion of predatory loans are originated by entities that benefit from preemption.

03-1106.htm, and has promulgated regulations that preempt a broad swath of state lending laws. 12 C.F.R. $\S 701.21$ (b) (2005). The Federal Deposit Insurance Corporation is also considering a Petition for Rulemaking to Preempt Certain State Laws, which may preempt state predatory lending laws as to the interstate operations of state-chartered members of the FDIC. Petition for Rulemaking to Preempt Certain State Laws, 70 Fed. Reg. 13,413-01 (Mar. 21, 2005). But again, FDIC-insured entities do not appear to be among the main predatory lenders. See STEPHEN M. BEARD FOR RUSSELl A. RAU, FDIC, THE DIVISION OF SUPERVISION and Consumer Protection's EXAMINATION Assessment of SubPrime Lending 2 (Audit Report No. 03-019) (2003) (estimating that less than 2\% of all FDIC-insured institutions had significant holdings of subprime assets).

473. The OCC has determined that as far as national banks are concerned, "there were 178 lenders whose business focus was subprime mortgage lending in 2001 . The majority, or $112(63 \%)$, were independent mortgage companies. Of the remaining lenders, $30(17 \%)$ were non-bank affiliates and only $36(20 \%)$ were depository institutions or their direct subsidiaries." Comptroller of the Currency Adm'r of Nat'l Banks, Economic Issues in Predatory Lending 4 (Office of Comptroller of the Currency, Working Paper, 2003), available at http://www.occ.treas.gov/workingpaper.pdf; see also WEICHER, supra note 59, at 30.

474. See, e.g., Chiwon Yom, Limited-Purpose Banks: Their Specialties, Performance, and Prospects, 17 FDIC BANKING REV. No. 1, at 19, 30 (2005) (describing First Union National Bank's acquisition of subprime lender The Money Store); Citigroup Closes Associates Deal, N.Y. TIMES, Dec. 1, 2000, at C12 (describing Citigroup's acquisition of subprime lender Associates First Capital Corporation); HSBC Holdings PLC: Regulators, Shareholders Clear Household International Deal, WALL ST. J., Mar. 31, 2003, at B4 (describing HSBC's acquisition of subprime lender Household International).

475. See, e.g., Andrew Ross Sorkin, HSBC to Buy a U.S. Lender for $\$ 14.2$ Billion, N.Y. TIMES, Nov. 15, 2002, at $\mathrm{Cl}$ (suggesting that most banks are concerned with reputational risks); Richard A. Oppel Jr. \& Patrick McGeehan, Along with a Lender, Is Citigroup Buying Trouble?, N.Y. TTMES, Oct. 22, 2000, § 3 , at 1 (describing Citigroup's reputational considerations upon entering subprime field).

476. Advisory Letter from David Hammaker to All CEOs, supra note 274, at 1-2. 


\section{Possible Congressional Preemption}

Two bills introduced in the 2005 congressional session address predatory lending. The Ney/Kanjorski Bill makes minor modifications to HOEPA that, while apparently consumer-friendly, come at the price of complete preemption of state predatory lending laws. ${ }^{477}$ In the same session, Representatives Barney Frank (D-MA), Brad Miller (D-NC) and Melvin Watt (D-NC) introduced an alternative bill that expressly does not preempt state predatory lending laws and models its substantive provisions on the stringent North Carolina predatory lending law. ${ }^{478}$ There is no evidence that either of these bills is likely to be passed this year.

Preemption, either regulatory or congressional, is premature, as Professor Azmy argues. ${ }^{479}$ Because predatory lending is difficult to define, the trial-and-error approach of the states has provided a fertile "laboratory" of experimentation. ${ }^{480}$ The Frank/Miller/Watt Bill recognizes this by adopting the useful provisions of the North Carolina law without preempting ongoing innovations by the states.

\section{B. GSEs Will Have an Incremental Impact}

Fannie Mae and Freddie Mac are the largest purchasers of residential mortgages on the secondary market and are becoming more significant players in the subprime market. Building on their buying guidelines for prime, conforming mortgages, Fannie Mae and Freddie Mac have issued guidelines so that subprime originators can design their loans to comply with their requirements.

Fannie Mae and Freddie Mac have indicated that they will not purchase high-cost home loans and other loans with certain terms that they deem to be abusive, such as harsh prepayment penalties. ${ }^{481}$ They have also indicated that they will not purchase high-cost home loans, as defined in the HOEPA. ${ }^{482}$ Fannie Mae has also indicated that it will not buy loans with mandatory arbitration clauses, and Freddie Mac has indicated that it will not buy loans originated with single-premium credit insurance. ${ }^{483}$

477. H.R. 1295, 109th Cong. $\S 102$ (lowering HOEPA points and fees trigger to five percent, albeit with a less restrictive definition of points and fees); id. $\$ 106$ (preempting state laws).

478. Prohibit Predatory Lending Act, H.R. 1182, 109th Cong. (2005); Legislative $U_{p-}$ date, supra note 276 , at 5 .

479. See Azmy, supra note 5, at 382-90.

480. See id. at 393; see also LI \& ERNST, supra note 24, at 19 (discussing the flaws inherent in the Ney-Kanjorski Bill and the similarity of the Miller-Watt-Frank Bill to existing successful state laws).

481. See sources cited supra note 176.

482. See supra note 176.

483. Id. 
The GSEs' buying guidelines are far less restrictive than the policies of the privileged raters. Because GSEs impact a smaller portion of the subprime market than the privileged raters do and because GSEs are only imposing incremental standardization on the subprime market, their impact should probably be more beneficial than not. ${ }^{484}$ Their impact will be beneficial not only because it is limited, but also because they have made good choices in drafting their buying guidelines: drawn neither too restrictively nor too broadly, they have identified genuinely problematic practices and loan terms to exclude. Whether the drafters of these guidelines were conscious of the GSEs' public interest duty or not, they struck a balance that few found fault with.

\section{Privileged Raters Are Standardizing the Subprime Market at the Expense of the Public Interest}

The privileged raters have indicated that they will not rate securities backed by pools of residential mortgages if any of those mortgages violate their rating guidelines relating to predatory lending laws. Because the lack of a rating from at least one of these agencies is the financial equivalent of a death sentence for a residential mortgagebacked securities offering, the privileged raters are able to impose their own form of standardization on the entire subprime market.

The privileged raters make more money in a growing residential mortgage-backed securities market because they charge issuers for their work in rating new securities; thus, it is in the agencies' selfinterest to keep states from passing laws that slow secondary market growth and cut into their income. Moreover, the privileged raters' own statements provide evidence that they are biased in favor of investors.

In addition to the theory that privileged raters are biased against the public interest, there are other hypotheses, presented below, that may explain their behavior. But even if these theories more accurately described the state of affairs, the history of the privileged raters' reaction to state predatory lending laws indicates that there are systemic problems that result from the ability of the privileged raters to sell regulatory licenses. ${ }^{485}$ Fundamentally, these problems derive from the power of the privileged raters to standardize the subprime market on their terms and their terms alone.

484. See William N. Eskridge, Jr., One Hundred Years of Ineptitude: The Need for Mortgage Rules Consonant with the Economic and Psychological Dynamics of the Home Sale and Loan Transaction, 70 VA. L. REV. 1083 (1984) (arguing that Fannie Mae and Freddie Mac are in the best position to standardize loan terms and balance consumer protection with market needs).

485. See supra note 238 and accompanying text. 
In response to the critique outlined in this Part, privileged raters may argue that the tension between their actions and state predatory lending legislation results from the fact that they are attempting to answer a different question than the one that the state legislatures want them to answer. Privileged raters, in their capacity as advocates for investors, may be concerned with the incredibly remote possibility of a catastrophic loss to a mortgage pool caused by a mammoth award in a predatory lending suit. The state may just want them to address the average risk and severity of such occurrences, which appear minimal. ${ }^{486}$ Thus, the privileged raters may argue there is no bias, just different goals.

This argument is not compelling. First, ratings, even investmentgrade ratings, are not intended to provide complete assurance of payment to investors, just an accurate assessment of that risk. ${ }^{487}$ Second, the risk of catastrophic loss is limited to the investors' investment in a given pool. ${ }^{488}$ This type of risk of catastrophic loss is no different from the risk that nearly all other securities bear for one reason or another; it is just the particular potential cause, predatory lending laws, that differs.

Privileged raters may also argue that while I have accurately described recent events and their negative consequences for the public interest, such localized consequences are acceptable "collateral damage" as the capital markets promote globalized standardization and efficiency. For this argument to have merit, it should demonstrate that the standardization that it is imposing is (1) relatively cost free and (2) a material, even if just incremental, improvement in the efficiency of the capital-markets. The first prong is materially false: predatory lending costs consumers many billions of dollars a year and preliminary studies suggest that predatory lending laws reduce predatory lending. ${ }^{489}$ And there is no evidence that the second prong is true: lenders are already required to comply with an extraordinarily complex set of regulations and the predatory lending statutes do not materially add to such compliance costs. Indeed, companies offer software packages to deal with the web of lending regulations. ${ }^{490} \mathrm{~A}$ related argument may be that the privileged raters should have the ability, at least more so than the states, to determine how the secondary market functions because they are bigger stakeholders in that

486. See supra note 348.

487. See Engel \& McCoy, Wall Street, supra note 32, at 716.

488. See supra note 108.

489. See, e.g., Quercia et al., supra note 283 (arguing that the North Carolina law reduced predatory loans without materially reducing subprime loans generally).

490. See, e.g., Appintelligence, http://www.appintelligence.com/preventpredatory/index.html (last visited Mar. 15, 2006) (describing web-based predatory lending due diligence product for lenders); ComplianceEase, http://www.complianceease.com/mainsite (last visited Mar. 15, 2006) (combining Internet-based compliance tool with insurance product). 
market. This, of course, would be an extraordinary transfer of power to private actors and should be the subject of an explicit decision making process, not the result of a slow and unseen accretion of power over decades.

Privileged raters might also argue that standardization that benefits investors ultimately benefits subprime borrowers because these two classes overlap, and the benefits to the former class negate the harm to the latter class. This argument, while somewhat intuitive, does not hold up at all. While there is, indeed, some overlap between the two classes, it is neither a significant overlap, nor is there a way to ensure that those harmed by the inappropriate standardization imposed by the privileged raters get a proportionate share of the benefits that accrue to the investor class generally.

Privileged raters might also argue that I am incorrect in describing their rating guidelines as inaccurate. They might argue that if that were so, others would be able to arbitrage loans governed by predatory lending statutes to their benefit. For instance, an investor might accept private placements of unrated pools containing loans governed by predatory lending statutes at a price that accurately reflects the risk of such statutes. While theoretically true, the fact is that the immense power of the privileged raters can dry up a mortgage market like Georgia's so quickly that there is no time for such an alternate market to develop.

Finally, privileged raters may argue that while I have accurately described recent events, I have misinterpreted them. They might argue that their predatory lending law guidelines are appropriate and unbiased. This position does not seem to have merit, given the biases demonstrated in this Article and given the less restrictive positions taken by GSEs. ${ }^{491}$

Fundamentally, the arguments of the privileged raters are quite hollow. There is every reason-from their own statements, to the empirical evidence, to the structure of their business models-to think that they take a proinvestor and/or pro-issuer stance on the policies that they evaluate. There is no reason to believe that the privileged raters are constituted to address the concerns of subprime

491. Moody's and Fitch may also argue that I am tarring them with too broad a brush, by grouping them with Standard \& Poor's, which has taken the most draconian approach to state predatory lending laws. For my purposes, the differences among the privileged raters are not that important because the typical securitization has ratings by both Moody's and Standard \& Poor's, at a minimum. See supra note 178 and accompanying text. The failure to get a rating from Standard \& Poor's would signal something is amiss to investors. Thus, the nature of the privileged raters' oligopoly is that the market and state legislatures must typically respond to the most draconian of Standard \& Poor's and Moody's. And, much like a "good cop, bad cop" duo, they both benefit from the systemic dilution of state predatory lending laws, notwithstanding the fact that one of the partners presents a more kindly face. 
borrowers, and there is no reason to believe that they consider the various sides of an issue as a legislature is likely (or, at least, more likely) to do. Thus, it appears that the standardization imposed upon the subprime market by the privileged raters is biased against the public interest and is not acceptable as "collateral damage" in the fight to create standardized capital markets.

\section{MAKING THE PRIVILEged RATERS TAKE RESPONSIBILITY FOR THEIR IMPACT ON THE PUBLIC INTEREST}

Rating agencies were historically considered to be mere commentators on the comings and goings of the players in our free market economy while ensuring that objective information is widely disseminated to all. ${ }^{492}$ This view, however, fails to take into account the privileged regulatory status that the SEC and other government regulators have granted to the privileged raters. And as the scope of that status increases, privileged raters have exploded in size and profitability. ${ }^{493}$ They now have a gatekeeper function in the secondary market, and they can allow their bias in favor of a growing secondary market to influence decisions that also affect matters of great concern to the public. This state of affairs should be remedied. The existing rating agency literature provides a starting point for solving the problem of rating agency bias.

The existing rating agency literature does not look at them from the public's perspective, this Article does. Rather, it looks at rating agencies from the perspective of investors and sometimes issuers. Nonetheless, the literature does suggest some ways to limit the excessive power of the privileged raters so as to protect the public interest:

(1) wait and see whether the subprime market standardizes in such a way as to make concerns about rating agency bias irrelevant,

(2) deregulate the privileged raters so as to remove their regulatory privileged status, and

(3) increase regulation of the privileged raters so as to ensure that they do not negatively impact the public interest.

\section{A. Wait and See}

If the history of the prime mortgage market is any guide, there is reason to believe that the subprime market will standardize over time and that many predatory behaviors will be driven from the 
market by various forces. In addition to the privileged raters, this Article has identified two standardizing forces: proposed federal legislation ${ }^{494}$ and the government-sponsored enterprises. ${ }^{495}$

Indeed, federal regulators are creating a unified regulatory regime that applies to many of the largest subprime lenders. This standardization, in itself, will not drive out predatory practices because the applicable federal standards are pro-issuer and because many of the predatory lenders are not subject to the federal regulatory regime..$^{496}$ The same holds true for the Ney/Kanjorski Bill. ${ }^{497}$ That is, the mere fact that the federal government is standardizing the subprime market does not mean that it is doing it in a way that helps subprime borrowers. ${ }^{498}$ The Frank/Miller/Watt Bill, on the other hand, may promote proconsumer standardization because it creates a floor of protections without limiting states from building additional protections from that floor. ${ }^{499}$

Fannie Mae and Freddie Mac are also driving some of the standardization in the subprime market. They are doing this by refusing to purchase loans with certain terms that they consider to be abusive. ${ }^{500}$ But while GSEs were able to impose standardization on the prime mortgage market, it is unclear that they will be able to do the same in the subprime mortgage market. The subprime market, unlike the early prime market, has a number of large lenders who need not follow the GSEs' lead. The subprime market also has, by definition, less consistency among its loan products. Thus, GSEdriven standardization, while potentially beneficial, does not offer a sure-fire way to end predatory behavior. The standardization imposed by the privileged raters is particularly troubling because they perform a gatekeeping function to the capital markets. This gatekeeping function gives an inordinate amount of power to the privileged raters and interferes with the market's ability to correct for the privileged raters' bias against the public interest.

Because no standardization push looks like it will standardize the subprime market in the near future and because predatory lending costs consumers billions of dollars each year, the wait-and-see approach does not offer much promise..$^{501}$

494. See supra notes $477-478$ and accompanying text.

495. See supra Part VI.B.

496. See Azmy, supra note 5, at 358.

497. See infra note $\mathbf{4 7 7}$ and accompanying text.

498. Id.

499. See supra note 471 and accompanying text.

500. See infra note 478 and accompanying text.

501. See Engel \& McCoy, Wall Street, supra note 32, at 744 ("Predatory lending continues to thrive despite claims that the market will correct the problem. Investors, who because of information asymmetries could potentially absorb some of the risks of predatory lending, are protected by pricing and securitization deals and, therefore, have no incentive 


\section{B. Deregulation}

There have been vociferous complaints that the SEC has created the privileged rater oligopoly. ${ }^{502}$ The SEC is in the process of issuing final, more transparent, rules regarding NRSRO designation. ${ }^{503}$ As noted above, the privileged raters have been criticized for a number of failings, not least of which is that they do not provide particularly accurate information. Some argue that increased competition from other rating agencies will increase the accuracy of the privileged raters' pronouncements. ${ }^{504}$ Such competition could push the privileged raters to accurately evaluate the risks associated with state predatory lending legislation, instead of adopting a biased view that helps secondary market players by reducing investors' risks and standardizing the operation of the secondary market at the expense of subprime borrowers.

Indeed, Professor Azmy has argued that experimentation by the states in the realm of predatory lending statutes has led to healthy innovation as states have struggled with the problem of predatory lending. ${ }^{505} \mathrm{~A}$ similar argument applies in the context of competition among rating agencies to provide the most accurate information to investors. ${ }^{506}$ The more rating agencies are involved in the assessment of the risks that predatory lending statutes pose to investors, the more likely that the secondary market will adopt appropriate standardization that would not be solely based on the terms of the privileged raters, but would also consider the interests of subprime borrowers. For this to occur, the pool of rating agencies must expand so that there is competition to provide the most accurate rating guidelines for predatory lending laws.

to police predatory lenders."). There are plenty of examples of industries with predatory practices that survive for decades, which also speaks against a wait-and-see approach. See, e.g., Benjamin Haggott Beckhart, 54 POL. SCI. Q. 268 (1939) (reviewing ALPHEUS ThOMAS Mason, THE BRANDEIS WAY: A CASE STUdY IN THE WoRKINGS OF DEMOCRACY (1938)) (describing long-term predatory practices in life insurance industry).

502. See supra Part IV.B.

503. Alec Klein, SEC Prepares to Change Rules for Credit Raters: Revision to Define National Designation, WASH. POST, Feb. 25, 2005, at E02.

504. Gretchen Morgenson, Wanted: Credit Ratings. Objective Ones, Please, N.Y. TTMES, Feb. 6, 2005, at D1, available at 2005 WLNR 1655972 (reviewing criticism of privileged rater oligopoly); Testimony of Sean J. Egan, Managing Director, Egan-Jones Ratings Company Before the House Subcommittee on Capital Markets, Insurance, and Government Sponsored Entities Nov. 29th Hearing-The Credit Rating Agency Duopoly Relief Act of 2005, available at http://financialservices.house.gov/media/pdf/112905se.pdf ("[A]dditional competition should encourage the issuance of timely, accurate ratings."). SEC representatives have argued, however, that market forces may keep the number of NRSROs down, whatever the application process. See Hill, supra note 33, at 57-59.

505. Azmy, supra note 5, at 391-94.

506. See Beaver et al., supra note 234 , at 7 (noting that regulation can reduce rating agency incentives to provide good services). 
Some commentators, including Professor Partnoy, have suggested that rating agencies should be extricated from government regulation altogether, leaving them as pure providers of information and ending their role as sellers of regulatory licenses. ${ }^{507}$ Partnoy has argued that regulators could substitute reliance on a rating with reliance on a "credit spread," which is "the difference between the yield on the bond and the yield on a risk-free bond of comparable structure and maturity." ${ }^{508}$ Such a system would return the privileged raters to their roots as providers of information and leave the granting of regulatory licenses to regulators. No one, at least in the academic literature, has persuasively demonstrated why this proposal is unworkable. ${ }^{509}$ Such a proposal would end the privileged raters' oligopoly and should increase the number of rating agencies that consider the impact of predatory lending statutes. Just as experimentation by the states is valuable to arrive at a well-balanced predatory lending law, empirical and analytic experimentation by multiple rating agencies will help the secondary market accurately evaluate the risk that such laws pose to investors.

Deregulating the privileged raters has much facial appeal,,${ }^{510}$ but ultimately, the problem with this proposal is that their ratings are deeply enmeshed with a broad array of regulatory regimes. ${ }^{511} \mathrm{De}$ coupling them throughout the international capital markets in order to resolve the problems of the subprime mortgage market (a signifi-

507. See, e.g., Partnoy, supra note 33, at 624 (arguing that SEC and other regulators should discontinue regulatory licensing "by excising the portions of their rules that depend substantively on credit ratings"); Lawrence J. White, Good Intentions Gone Awry: A Policy Analysis of the SEC's Regulation of the Bond Rating Industry (NYU Public Law and Legal Theory Working Papers, Working Paper No. 10, 2005), available at http://sr.nelloo.org/nyu/ plltwp/papers/10 (proposing that financial regulators "cease delegating their safety-andsoundness judgments to" privileged raters).

508. Partnoy, supra note 33 , at $705 \mathrm{n}, 388$.

509. Cf. SEC, REPORT, supra note 211, at $39 \mathrm{n} .106$ (quoting Steven Schwarcz that "[r]ating agencies are, and are intended to be, more conservatively stable" (than credit spreads) (alterations in original)).

510. Indeed, the privileged raters themselves sometimes recommend this course. See Jerome S. Fons, Policy Issues Facing Rating Agencies, in RATINGS, RATING AGEnCIES AND THE Global FinANCIAL SYSTEM, supra note 141, at 341. ("Historically, the major rating agencies have been against the use of credit ratings in the regulatory process due to potential impact of rating changes on financial markets, incentives to engage in ratingsshopping, the accuracy of ratings in reflecting the underlying risks, the use of ratings as 'automatic pilot' substitutes for proper credit analysis by lenders and investors, and the pressure that might be brought to bear on the agencies if they were to become too closely tied to the regulatory process-including regulation of the agencies themselves."). It is unclear whether this stance is principled or opportunistic (i.e., privileged raters continue to benefit from their privileged regulatory status while denying that it is important to their business model).

511. See, e.g., BASEL Comm. on Banking Supervision, InTERnational Convergence of CAPITAL MEasuremenT AND CAPITAL STANDARDS: A REVISED FramewORK (2004) (describing new international standards for risk-based capital requirements that heavily relies on rating agencies). 
cant, but small part of the entire international financial system) might amount to letting the tail wag the dog. If deregulation of privileged raters is ultimately accomplished, it will be as a result of broader forces than those present in the subprime market.

\section{Increased Regulation}

Some have argued that rating agencies should be subject to greater regulation, as they are active participants in the secondary market underwriting process. ${ }^{512}$ Regulation can take a number of forms, including traditional oversight by means of inspections and record-keeping requirements, government input into the ratings process itself, and some kind of periodic public review of the performance of the privileged raters.

There is general agreement that traditional regulation of rating agencies will not be helpful as it is in other industries, such as banking. ${ }^{513}$ Professor Steven Schwarcz warns that government input into the ratings process itself may impair the quality and perceived quality of agency ratings:

[I]f rating agency regulation were based on factors other than economic efficiency, ratings would to some extent reflect those other factors. Investors, who typically look for the highest economic return for a given level of safety, then would be misled, undermining their confidence in the rating system and their willingness to invest in rated securities. ${ }^{514}$

Professor Schwarcz argues that, at least "[i]n an economic context, where health and safety are not at issue, regulatory policy generally views" efficiency as the most important concern of any given regulatory regime, although he does acknowledge that "[a]n exception might arise, however, where society has objectives in addition to economic efficiency," such as distributional objectives. ${ }^{515}$ Here, while there are no distributional objectives, there is a concern that the privileged raters have a negative impact on the public interest that must be addressed. Nonetheless, Schwarcz is right to warn regulators not to kill the rating agency goose to get to the golden egg of

512. See Gerard Uzzi, Note, A Conceptual Framework for Imposing Statutory Underwriter Duties on Rating Agencies Involved in the Structuring of Private Label MortgageBacked Securities, 70 ST. JoHN's L. REV. 779, 798 (1996) (arguing that rating agency regulation is "inevitable").

513. See Hill, supra note 33, at 87-88 ("Monitoring can fairly well be designed to catch egregious shirking or fraud. But monitoring with the end of making lax behavior less lax should be less successful. The result is likely to generate make-work, with no real improvement. Where rating agencies are failing is not in the increment that traditional monitoring of this type could capture.").

514. Schwarcz, supra note 33 , at 13.

515. Id. at 10-11 (footnotes omitted). 
bias-free ratings. The final possible type of regulation, increased public comment, may help reduce that bias without interfering with the content of the ratings themselves.

There have been a variety of proposals for increased public scrutiny regarding the privileged raters, ranging from opportunities to comment to the right to appeal rating decisions. One proposal has been to adopt a process like that used to renew broadcast licenses. ${ }^{516}$ Under this proposal, NRSRO status would be periodically reviewed and the public would be given the opportunity to comment. This proposal rests on the assumption that NRSRO status will not be threatened if there are public complaints, but rather that the privileged raters will (like broadcasters) seek to avoid public shaming for acting inappropriately. ${ }^{517}$ While this proposal has merit, it is clearly no panacea.

The SEC's 2005 Rule Proposal has made the increased regulation of privileged raters a timely proposal. The renewal of broadcasting licenses provides a good precedent for what that increased regulation can look like. And, while renewal proceedings will not be a panacea (keeping in mind that Standard \& Poor's withstood some virulent criticism for its actions in New Jersey), they should offer a forum for addressing the negative impact that the privileged raters have on the public interest.

Francis Bottini has proposed that the SEC be granted the power to issue a "Writ of Review" to a rating agency to suggest that the agency reconsider a rating. ${ }^{518}$ This proposal could be expanded to grant the SEC the power to suggest that a rating agency reconsider an underwriting standard that appears to be too conservative or biased against the public interest. If such a power were granted as part of greater regulatory oversight of NRSROs, it might be an effective means of ensuring that privileged raters did not let their biases interfere with their predatory lending legislation guidelines. Working out the details of such a proposal must be left to another article and would probably only make sense as part of an overhaul of the entire regulatory scheme for NRSROs.

\section{CONCLUSION}

Subprime lending has given low- and moderate-income homeowners some of the same financial options and resources that had been previously reserved for prime borrowers. Unfortunately, this positive

516. See Hill, supra note 33 , at 88 (describing proposals of Fidelity and the Investment Company Institute).

517. Id.

518. Francis A. Bottini, Jr., Comment, An Examination of the Current Status of Rating Agencies and Proposals for Limited Oversight of Such Agencies, 30 SAN DIEGo L. REv. 579, 613 (1993). Some rating agencies allow issuers to informally appeal a rating prior to it being released to the public. Rhodes, supra note 181, at 314 . 
development has been shadowed by the growing problem of predatory lending. This Article builds on work of other scholars who have demonstrated how the structure of the secondary market has allowed predatory lending to explode in the subprime market. It ties this literature to the ratings agency literature which suggests that privileged raters are biased against the public interest.

This Article demonstrates how privileged raters have allowed their biases to interfere with state efforts to end predatory lending in their jurisdictions. This Article then vets proposed privileged rater reforms and concludes that increased regulation of privileged raters is called for to ensure that there is a way to hold them accountable for their actions that negatively impact the public interest.

This Article has implications for two important and broader areas of study: (1) the gatekeeping function of privileged raters in the international financial markets ${ }^{519}$ and (2) the replacement of local property law regimes with international, investor-friendly regimes as globalization increases. ${ }^{520}$ By making visible the impact of privileged raters on state predatory lending laws, this Article makes clear that the increased standardization that benefits the international investment community comes at a cost to localized concerns like consumer protection. By doing so, it provides a theoretical basis for arguing that regulators of rating agencies should consider the public interest when regulating rating agencies.

519. The "gatekeeping" literature has, like most of the literature regarding rating agencies, focused on the impact of regulation on investors, not the public interest. See, e.g., Peter B. Oh, Gatekeeping, 29 J. CoRP. L. 735, 741 (2004) (describing gatekeeping function as a "duty to investors").

520. See, e.g., Marc R. Poirier, The NAFTA Chapter 11 Expropriation Debate Through the Eyes of a Property Theorist, 33 ENVTL. L. 851 (2003) (arguing that NAFTA inappropriately replaces local regimes of property law with investor-friendly ones). 
